\title{
Variations in Soil Detachment Rates after Wildfire as a Function of Soil Depth, Flow Properties and Root Properties
}

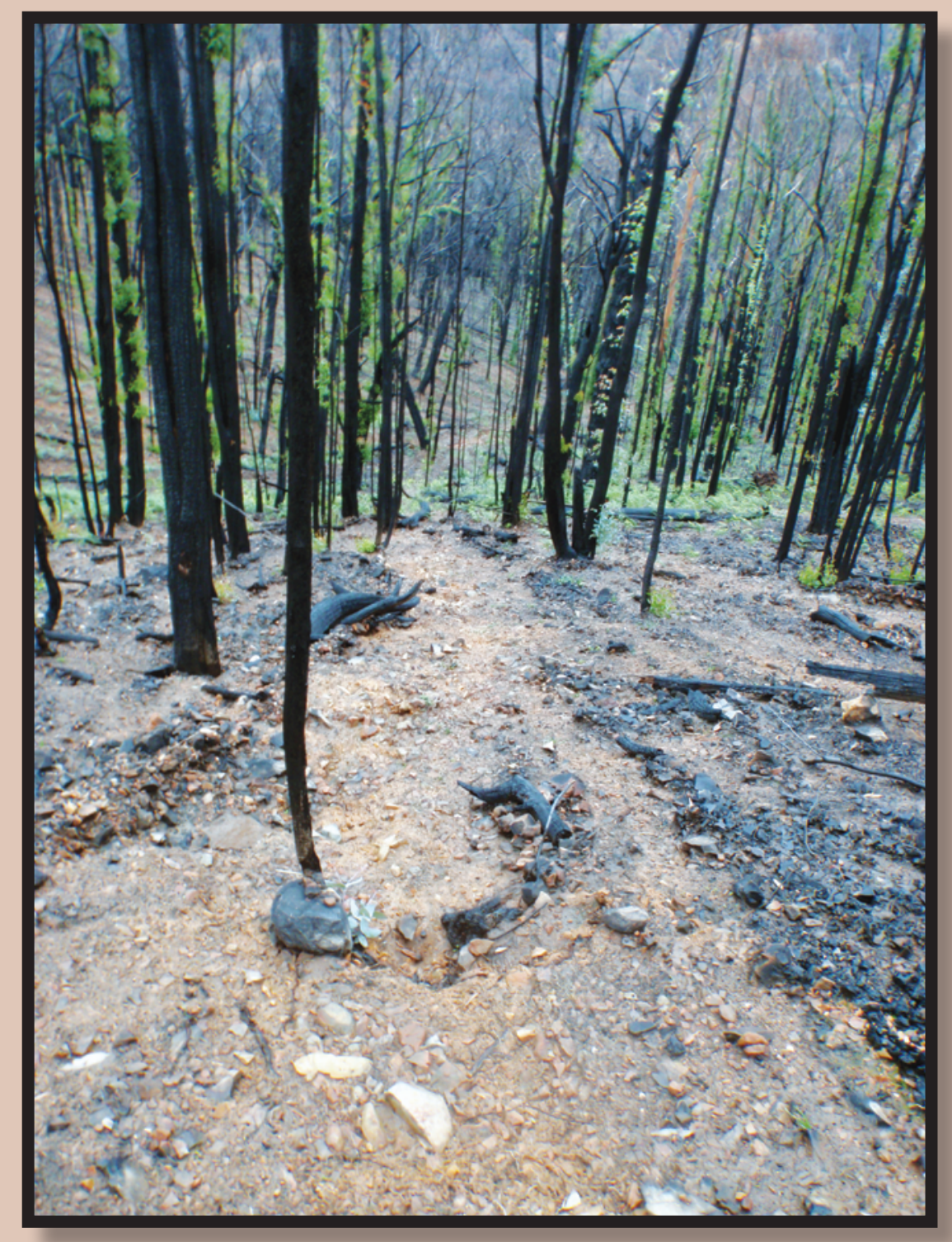

Scientific Investigations Report 2012-5233 
COVER. Looking down a hillslope in the Sunday Creek Catchment in Victoria, Australia about $50 \mathrm{~km}$ north of Melbourne after the wildfires of February 2009 (photo taken in April 2009 by Petter Nyman). 


\section{Variations in Soil Detachment Rates after Wildfire as a Function of Soil Depth, Flow Properties and Root Properties}

By John A. Moody and Petter Nyman

Scientific Investigations Report 2012-5233 


\title{
U.S. Department of the Interior \\ KEN SALAZAR, Secretary
}

\author{
U.S. Geological Survey \\ Suzette M. Kimball, Acting Director
}

U.S. Geological Survey, Reston, Virginia: 2013

For more information on the USGS - the Federal source for science about the Earth, its natural and living resources, natural hazards, and the environment, visit http://www.usgs.gov or call 1-888-ASK-USGS.

For an overview of USGS information products, including maps, imagery, and publications, visit http://www.usgs.gov/pubprod

To order this and other USGS information products, visit http://store.usgs.gov

Any use of trade, firm, or product names is for descriptive purposes only and does not imply endorsement by the U.S. Government.

Although this information product, for the most part, is in the public domain, it also may contain copyrighted materials as noted in the text. Permission to reproduce copyrighted items must be secured from the copyright owner.

Suggested citation:

Moody, J.A., and Nyman, P., 2013, Variations in soil detachment rates after wildfire as a function of soil depth, flow properties, and root properties: U.S. Geological Survey Scientific Investigations Report 2012-5233, 40 p. 


\section{Contents}

Abstract

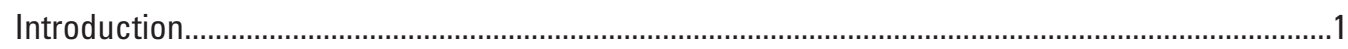

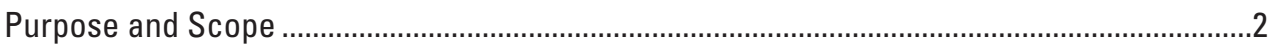

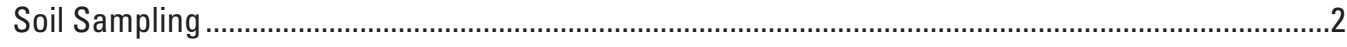

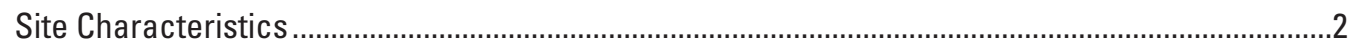

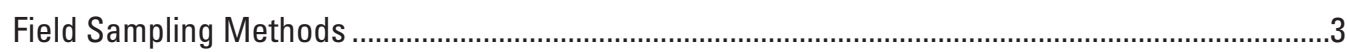

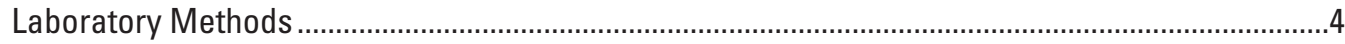

Soil Physical Properties.....................................................................................................

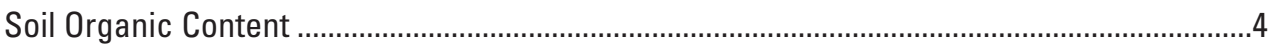

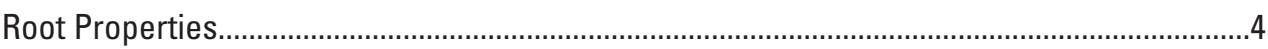

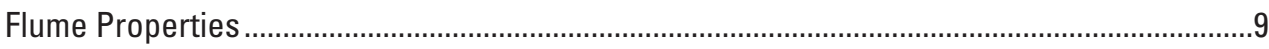

Boundary Shear Stress ..............................................................................................

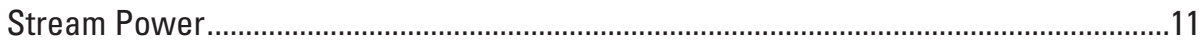

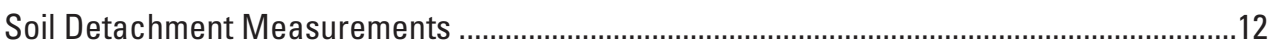

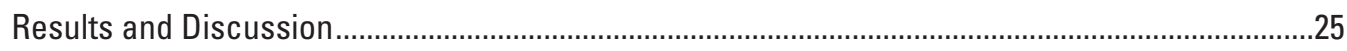

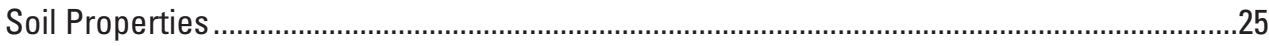

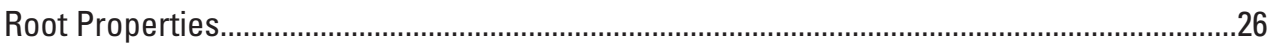

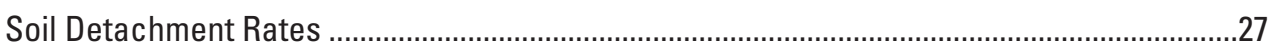

Non-Uniform Shear Stress and Root-length Density....................................................28

Non-Uniform Unit Stream Power and Root-length Density ............................................30

Multiple Regressions using Flow and Root Variables ....................................................31

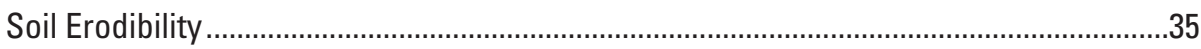

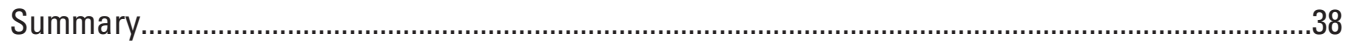

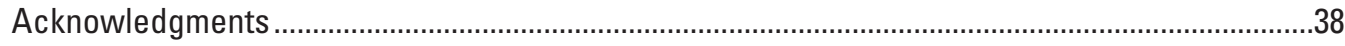

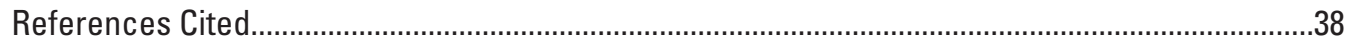

\section{Figures}

1. A, Upper section shows the location for collecting cluster samples $(A, B$, and $C$ ) along transects (T1, T2, and $\mathrm{T} 3$ ) from one sample site called

Fourmile Canyon South. B, Lower section shows the details of the method of collecting subsamples of the soil core .......................................................................

2. Extracted roots from $3-5 \mathrm{~cm}$ below the soil surface from burned sites............................8

3. Calibration of the grid method of measuring root length outlined by Tennant (1975) by comparing the root lengths measured manually using metric

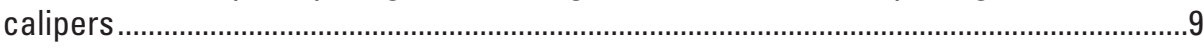

4. Diagram of shallow-water tilting flume and circulation system......................................10

5. Relations between water discharge and water depth, at different slopes, for the shallow-water tilting flume...............................................................................1

6. Comparison of non-uniform shear stress measured for the tilting flume with a smooth bed conditions and with a soil core in place

7. Mean bulk density of soil for three sites based on three replicates for each cluster 
8. Loss on ignition (LOI) of soil for three sites based on three replicates for each cluster.....

9. Percent silt and clay (less than $0.063 \mathrm{~mm}$ ) in soil for three sites based on three replicates for each cluster......

10. Root density as a function of depth in the soil for three sites based on three replicates for each cluster.

11. Root-length density as a function of depth in the soil for three sites based on one

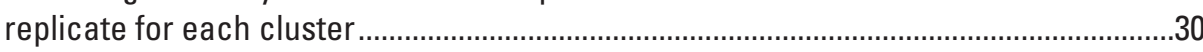

12. Relations between root-length density and root density ..............................................31

13. Comparison of the goodness-of-fit as measured by the coefficient of determination for power law relations between the detachment rate and the non-uniform shear stress or the root-length density.

14. Exponents of the independent variables used in multiple regressions of log transformed data in which detachment rate for greater than $0.063 \mathrm{~mm}$ size fraction is the dependent variable.....

15. Multiple regression model for detachment rates using all shear stress, stream power, and root-length density data for clusters collected in burned areas... .35

16. Relations between detachment rate for all data and $A$, Non-uniform shear stress and $B$, Non-uniform stream power 36

17. Photographs of the appearance of the surface of the soil core in the tilting flume.........37

\section{Tables}

1. Soil and root properties for Fourmile Canyon South site .5

2. Soil and root properties for Fourmile Canyon North site ..................................................6

3. Soil and root properties for Pozo South site...

4. Hydrologic parameters and sedimentologic results for soil core samples collected at the Fourmile Canyon South site

5. Hydrologic parameters and sedimentologic results for soil core samples collected at the Fourmile Canyon North site.

6. Hydrologic parameters and sedimentologic results for soil core samples collected at the Pozo South site

7. Multiple regression information for the detachment rate as a function of root-length density and either non-uniform shear stress or non-uniform stream power 


\title{
Conversion Factors and Abbreviations
}

SI to Inch/Pounds

\begin{tabular}{|c|c|c|}
\hline Multiply & By & To obtain \\
\hline \multicolumn{3}{|c|}{ Length } \\
\hline millimeters (mm) & 0.0393701 & inch (in.) \\
\hline centimeter $(\mathrm{cm})$ & 0.393701 & inch (in.) \\
\hline square centimeter $\left(\mathrm{cm}^{2}\right)$ & 0.155000 & square inch (in..$\left.^{2}\right)$ \\
\hline centimeter per second $\left(\mathrm{cm} \mathrm{s}^{-1}\right)$ & 0.032808 & foot per second $\left(\mathrm{ft} \mathrm{s}^{-1}\right)$ \\
\hline milliliters per second $\left(\mathrm{mL} \mathrm{s}^{-1}\right)$ & 0.000035315 & cubic foot per second $\left(\mathrm{ft}^{3} \mathrm{~s}^{-1}\right)$ \\
\hline \multicolumn{3}{|c|}{ Weight } \\
\hline milligram (mg) & 0.000035274 & ounces (oz) \\
\hline $\operatorname{gram}(\mathrm{g})$ & 0.0022046 & pound (lb) \\
\hline gram per cubic centimeter $\left(\mathrm{g} \mathrm{cm}^{-3}\right)$ & 62.42796 & pounds per cubic foot $\left(\mathrm{lb} \mathrm{ft}^{-3}\right)$ \\
\hline dyne & 0.000035969 & ounce-force (oz) \\
\hline dyne & 0.0000022481 & pound-force (lb) \\
\hline dyne per square centimeter $\left(\right.$ dyne $\left.\mathrm{cm}^{-2}\right)$ & 0.0000145038 & pound per square inch $\left(\mathrm{lb}^{-\mathrm{in}^{-2}}\right)$ \\
\hline erg per second (erg s$\left.{ }^{-1}\right)$ & 0.0002655 & foot-pound per hour (ft-lb h-1) \\
\hline \multicolumn{3}{|c|}{ Soil erodibility } \\
\hline $\begin{array}{l}\text { metric ton-hectare-hour per hectare- } \\
\text { megajoule-millimeter (t-ha-h } \\
(\text { ha-MJ-mm) }\end{array}$ & 7.593 & $\begin{array}{l}\text { ton-acre-hour per hundreds of } \\
\text { acre-foot-tonf-inch }\end{array}$ \\
\hline
\end{tabular}

\section{Abbreviations}

$\pm \quad$ Plus and minus

$<\quad$ Less than

$>$ Greater than

$\sim$ Approximately

FMC Fourmile Canyon

RD Root density

RLD Root-length density

\section{Units of Measure Used in This Report}

\author{
$\mathrm{cm} \quad$ centimeter \\ dyne $\mathrm{cm}^{-2} \quad$ dynes per square centimeter \\ erg s${ }^{-1} \mathrm{~cm}^{-2} \quad$ erg per second per square centimeter \\ $\mathrm{mm} \quad$ millimeter \\ $\mathrm{g} \mathrm{s}^{-1} \mathrm{~cm}^{-2} \quad$ grams per second per square centimeter
}

$\mathrm{s} \quad$ second 



\title{
Variations in Soil Detachment Rates after Wildfire as a Function of Soil Depth, Flow Properties, and Root Properties
}

\author{
By John A. Moody ${ }^{1}$ and Petter Nyman²
}

\section{Abstract}

Wildfire affects hillslope erosion through increased surface runoff and increased sediment availability, both of which contribute to large post-fire erosion events. Relations between soil detachment rate, soil depth, flow and root properties, and fire impacts are poorly understood and not represented explicitly in commonly used post-fire erosion models. Detachment rates were measured on intact soil cores using a modified tilting flume. The cores were mounted flush with the flume-bed and a measurement was made on the surface of the core. The core was extruded upward, cut off, and another measurement was repeated at a different depth below the original surface of the core. Intact cores were collected from one site burned by the 2010 Fourmile Canyon (FMC) fire in Colorado and from one site burned by the 2010 Pozo fire in California. Each site contained contrasting vegetation and soil types. Additional soil samples were collected alongside the intact cores and were analyzed in the laboratory for soil properties (organic matter, bulk density, particle-size distribution) and for root properties (root density and root-length density).

Particle-size distribution and root properties were different between sites, but sites were similar in terms of bulk density and organic matter. Soil detachment rates had similar relations with non-uniform shear stress and non-uniform unit stream power. Detachment rates within single sampling units displayed a relatively weak and inconsistent relation to flow variables. When averaged across all clusters, the detachment rate displayed a linear relation to shear stress, but variability in soil properties meant that the shear stress accounted for only a small proportion of the overall variability in detachment rates $\left(\mathrm{R}^{2}=0.23 ; \mathrm{R}^{2}\right.$ is the coefficient of determination). Detachment rate was related to root-length density in some clusters $\left(\mathrm{R}^{2} \mathrm{val}-\right.$ ues up to 0.91$)$ and unrelated in others $\left(\mathrm{R}^{2}\right.$ values $\left.<0.1\right)$. The overall $\mathrm{R}^{2}$ value improved and the range of exponents became narrower by applying a multivariate regression model where boundary shear stress and root-length density were included as explanatory variables. This suggests that an erodibility

\footnotetext{
${ }^{1}$ U.S. Geological Survey, USA

${ }^{2}$ University of Melbourne, Australia
}

parameter which incorporates the effects of both flow and root properties on detachment could improve the representation of sediment availability after wildfire.

\section{Introduction}

Sediment availability is a critical, but relatively unknown variable needed to predict post-wildfire sediment erosion and transport as well as debris flow propagation in mountainous terrain (Moody and Martin, 2009; Nyman and others, 2011). Soils on unburned forested hillslopes in mountainous terrains generally have three layers: (1) a litter layer of loosely interwoven organic material, (2) a duff (or humus) layer consisting of partially to completely decomposed litter material that is more rigid and compressed than the litter layer, and (3) a cohesive soil layer with some organic material (DeBano and Neary, 2005; DeBano and others, 2005). The upper two layers protect the underlying cohesive soil layer from erosion. Wildfires alter this structure in severely burned areas by combusting the organics and mixing in (by thermally driven winds) mineral soil particles with the combustion products to produce a layer of non-cohesive material consisting of ash, charcoal, and soil mineral that overlays the cohesive soil matrix. In less severely burned soils, an intact duff layer (that portion of the duff that did not burn) may be sandwiched between the top non-cohesive layer and the soil cohesive layer. Soil detachment rates would be expected to vary between such different soil layers.

Detachment rates for particles within the non-cohesive layer have been determined by flow properties (such as shear stress or stream power) and particle properties (such as the critical shear stress or stream power) for initiation of motion and represent a "transport-limited case" (Foster and Meyer, 1975; Hairsine and Rose, 1992). For the cohesive soil matrix layer, detachment rates for a given shear stress depend on the cohesive properties of the matrix as a whole, which are controlled by cohesive bonds of clay particles forming soil aggregates (Blake and others, 2007) and adhesive bonds of roots that hold the soil (Gyssels and others, 2005; De Baets and others, 2007; Grabowski and others, 2011) and produce the "detachment-limited case" (Foster and Meyer, 1975; Hairsine 
and Rose, 1992). In addition to the cohesive properties, other variables can possibly affect detachment rates, such as armoring by larger particles and roots (or scouring around these elements) and the degree of water repellency. Water repellency can be relatively high in the organic component of soils unaffected by wildfire, and can be elevated by the combustion process in soils affected by wildfire (DeBano, 2000).

The thickness of the post-wildfire erodible surface layer depends on the fuel load in the O-horizon/duff and A-horizon and on the soil burn severity, which determines the thickness of ash. The soil burn severity also changes the cohesive properties of the B-horizon by altering root strength (Busse and DeBano, 2005) and weakening organic bonds (Giovanni and others, 1988), which in turn affect the critical shear stress for the detachment mineral soil particles (Moody and others, 2005). Thus, the total thickness of this erodible surface layer and the associated erodibility are the data that are needed to determine sediment availability.

There is a large volume of literature on the erodibility of agricultural soils from measurements made in the field (Elliot and others, 1989). However, less data is available for soils typical of mountainous regions susceptible to wildfire (Robichaud and others, 2010; Sheridan and others, 2007; Al-Hamdan and others, 2011), and most erodibility parameters have been calculated for surface material and not as a function of depths below the soil surface, which becomes a logistical problem in the field and better explored in a laboratory flume (Nachtergaele and Poesen, 2002). Erodibility does not have a consistent definition in the literature, because the detachment rate $\left[\mathrm{g} \mathrm{s}^{-1} \mathrm{~cm}^{-2}\right]$ is normalized by different flow variables (Moody and others, 2005; Grabowski and others, 2011) or detachment rate is expressed as a ratio of the actual rate to a rate expected for non-cohesive single-size sediment (Hairsine and Rose, 1992).

\section{Purpose and Scope}

This report presents the results of a set of laboratory flume experiments designed to measure the detachment rates for non-cohesive and cohesive soils as a function of depth below the soil surface. Soil cores were collected from unburned and burned hillslopes in two different precipitationwildfire regimes: one in Colorado and one in California. Soil detachment rates in this report are linked to corresponding measurements of soil properties as a function of depth (soil bulk density, particle-size distributions, organic matter content), root properties (root mass and root-length density), and to the hydraulic variables (water depth, discharge, shear stress, and stream power) such that the reader can investigate detachment rates in burned soils or use the data to calculate a desired erodibility parameter.

Relations between detachment rate and hydraulic variables and root properties as a function of soil depth are presented. Power law relations are determined for replicate samples from the two different precipitation-fire regimes in order to assess the natural variability of soil erodibility after wildfire.

\section{Soil Sampling}

Detachment of sediment particles from soil depends primarily on the degree of cohesion holding particles together, which can be a function of the particle size and distribution of vegetative roots in the soil profile. Thus, the sampling strategy was designed to collect soil samples from recently burned areas with contrasting geology, soil-particle size, and vegetative characteristics. One area had been burned by the 2010 Fourmile Canyon fire in September 2010, and typically had sandy-gravelly soils with different types of coniferous vegetation on different aspects. A second area had been burned by the 2010 Pozo fire in August 2010, and typically had clayey soils and chaparral vegetation.

\section{Site Characteristics}

The area burned by the 2010 Fourmile Canyon fire was in the Front Range of the Rocky Mountains near Boulder, Colorado. This area has a Continental climate (Pepin, 2000) where the precipitation is primarily a mix of cyclonic storms in the spring and fall, convective storms in the summer, and snowstorms in late fall through early spring. Mean annual precipitation (map) from nearby Gross Reservoir consists of rain (346 millimeters ( $\mathrm{mm})$ ) during the late spring, summer, and early fall (April-September) and snow during the remainder of the year $(175 \mathrm{~mm})$ or total annual precipitation of $521 \mathrm{~mm}$ (National Oceanic and Atmospheric Administration, 2000). Cores were collected at elevations between 2,350 and 2,450 m on a northand on a south-facing site with hillslope lengths on the order of 200-400 meters (m) and slopes of 20-30 . The Fourmile Canyon fire burned through primarily ponderosa pine (Pinus pondersosa) and Rocky Mountain juniper (Juniperus scopulorum) on south-facing slopes and primarily Douglas fir (Pseudotsuga menziesii subspecies glauca) and limber pine (Pinus flexilis) on north-facing slopes. Soils on the south-facing site are stony and gravelly sandy loams described by the U.S. Department of Agriculture (USDA) Survey Staff (2011) as frigid Lithic Haplustolls with relatively high mica content and derived from granitic bedrock (Gable, 1980). Soils on the north-facing site are derived from granodiorite and are primarily coarse to fine sandy-gravelly soils and classified as frigid Lamellic or Typic Haplustalfs (Gable, 1980; U.S. Department of Agriculture Survey Staff, 2011). The USDA database lists these soils as having a RUSLE2 surface soil erodibility factor, $\mathrm{K}_{\mathrm{f}}\left[\mathrm{cm}^{-1}\right]$, of 0.026 t-ha-h (ha-MJ-mm) ${ }^{-1}$ on south-facing hillslopes and 0.037 t-ha-h (ha-MJ-mm) ${ }^{-1}$ on north-facing hillslopes.

The area burned by the 2010 Pozo fire was in the La Panza Mountains, which are part of the central California Coastal Mountains near San Luis Obispo, California. The 
mountains are inland and partly in the rain shadow from the Santa Lucia and Garcia Mountains closest to the coast (map = $817 \mathrm{~mm}$; Santa Margarita Boost; National Oceanic and Atmospheric Administration, 2000) and the average annual precipitation is $570 \mathrm{~mm}$, which falls primarily in the winter months of December-March (Salinas Dam; National Oceanic and Atmospheric Administration, 2000). This rainfall pattern is typical of a Mediterranean climate. At this site, cores were collected at elevations between 500 and $580 \mathrm{~m}$ on short (50-100 m), steep $\left(20-40^{\circ}\right)$ south-facing hillslopes. The Pozo fire burned through chaparral vegetation consisting of scattered blue oak (Quercus douglasii), manzanita (Arctostaphylos sp.), chamise (Adenostoma sp.), and white sage (Salvia apiana). Soils are fine clay loams classified as thermic Mollic Haploxeralfs, and at lower elevations, these soils grade into fine, smectitic, thermic Typic Haploxererts (U.S. Department of Agriculture Survey Staff, 2011) that are mostly derived from bedrock geology consisting of marine sedimentary rocks (U.S. Forest Service, 2011). Soils at higher elevations have values of $\mathrm{K}_{\mathrm{f}}$ of $0.057 \mathrm{t}$-ha-h (ha-MJ$\mathrm{mm})^{-1}$ and soils at lower elevations have values ranging from 0.026-0.032 t-ha-h (ha-MJ-mm) ${ }^{-1}$.

\section{Field Sampling Methods}

To obtain representative samples, soil cores were collected along transects starting near a ridge line and extending down the hillslope. In the Fourmile Canyon area, there were two sites. The first site was on south-facing hillslopes (FMCSouth) with three 80-m transects on a burned hillslope and one $80-\mathrm{m}$ transect on an unburned hillslope. The second site was on north-facing hillslopes (FMC-North) with three 80-m transects on a burned hillslope and one 80-m transect on an unburned hillslope. In the Pozo area, there was one site on south-facing hillslopes (Pozo-South) with three 40-m transects on burned south-facing hillslopes and one $40-\mathrm{m}$ transect on an unburned hillslope. Soil cores were collected at nine equally spaced locations along each transect. The first three, the middle three, and the last three locations were combined to form three separate composite transect samples that would characterize particle size and root properties of the burned hillslope. The three composite transect samples were archived for later analysis by any interested researchers.

At one location (judged to be the most representative) along each of three transects, 11 additional soil cores were collected (fig. 1A). Five were collected to measure soil detachment rates in a shallow water, tilting laboratory flume, three replicate soil cores were collected, within about a 1-m diameter area, to characterize the particle size and organic matter, and three replicate soil cores were collected to characterize root properties of the soil cores used in the flume (fig. 1B). This group of 11 cores is called a cluster in this report, and thus, there were three clusters (A, B, and C) for each site on a burned hillslope, one cluster for each unburned site, and a total of 12 clusters from the three different sites

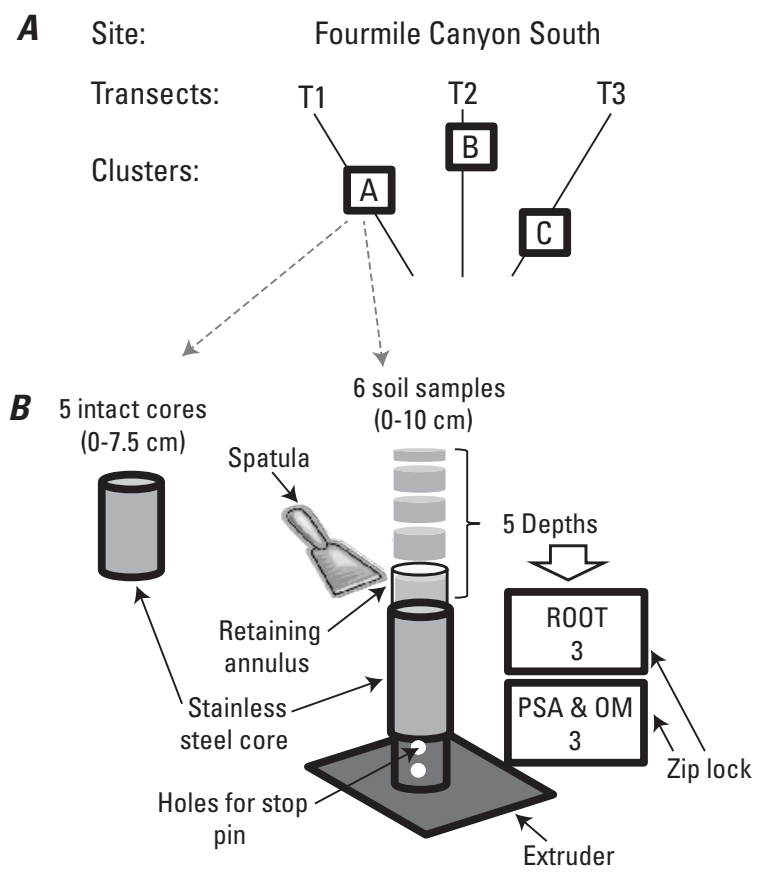

Figure 1. A, upper section shows the location for collecting cluster samples $(A, B$, and $C)$ along transects (T1, T2, and T3) from one sample site called Fourmile Canyon South. $B$, lower section shows the details of the method of collecting subsamples of the soil core. Stainless steel pins are inserted into a series of holes in a solid plastic cylinder to provide stops as the core is slid down the extruding cylinder mounted to a base. At each stop, the protruding soil is retained inside a plastic annulus and then sliced at the bottom of the annulus by using the spatula to separate a subsample, which is put in labeled "zip-lock" sample bags.

(FMC-South, FMC-North, and Pozo-South). Only the data from the cluster samples are given in this report.

Each soil core was divided into five subsamples representing different depths below the surface. Soil cores (4.7- $\mathrm{cm}$ diameter) collected for particle size and root properties were $10-\mathrm{cm}$ long, and those cores for soil detachment measurements in the flume were $7.5-\mathrm{cm}$ long. The core tubes were driven into the ground with a mallet, excavated by using a flat trowel slid under the bottom of the core tube, and subsamples were extruded from the core using a solid plastic cylinder mounted on a flat base at the following depth intervals: $0-1 \mathrm{~cm}, 1-3 \mathrm{~cm}, 3-5 \mathrm{~cm}, 5-7.5 \mathrm{~cm}$, and $7.5-10 \mathrm{~cm}$. In some cases, the core hit a pebble or rock, the core edge was re-sharpened or a spare core was used, and a new location was tried until a complete core was obtained. It was easier to obtain a full, intact core using the $7.5-\mathrm{cm}$ long cores than using the 10-cm long cores.

Each subsample was placed in a separate zip-lock bag and taken back to the laboratory for analysis (fig. 1). Soil cores for soil detachment measurements were excavated by 
using the flat trowel, but then each end of the core was capped tightly to prevent shifting of the core inside the core tube. Core tubes were labeled and were brought back to the laboratory and refrigerated until they were used in the flume. At each sampling location, notes were made on the general characteristics of the location such as the proximity to trees and other plants or shrubs. The site itself was further characterized in terms of plant species, the density of plants (stems per hectare, stems ha ${ }^{-1}$ ), size of trees (basal area and diameter at breast height), and shrubby vegetation and ground cover. Visual observations of root structure were made in the field and some photographs were obtained of root networks that were exposed either in a trench or by removing topsoil using a jet of water (data on file at U.S. Geological Survey Office in Boulder, Colorado).

\section{Laboratory Methods}

Soil and root properties were analyzed at the fixed depth intervals corresponding to the depth intervals of the subsamples collected in the field, whereas the soil detachment measurements were made at five depths approximately equal to the midpoint of each depth interval. Soil properties were bulk density $\left[\mathrm{g} \mathrm{cm}^{-3}\right]$, particle size distribution, and organic content; and root properties were root density $\left[\mathrm{mg} \mathrm{cm}^{-3}\right]$ and root-length density $\left[\mathrm{cm} \mathrm{cm}^{-3}\right]$. Soil detachment measurements include: flume properties, hydraulic properties (slope, water depth $[\mathrm{mm}]$, and discharge $\left[\mathrm{mL} \mathrm{s}^{-1}\right.$ ), shear stress [dynes $\left.\mathrm{cm}^{-2}\right]$, stream power $\left[\mathrm{erg} \mathrm{s}^{-1} \mathrm{~cm}^{-2}\right]$, soil detachment rates $\left[\mathrm{g} \mathrm{cm}^{-2} \mathrm{~s}^{-1}\right]$, and eroded sediment particle-size distributions.

\section{Soil Physical Properties}

Each cluster had three replicate soil samples of the source material collected at five different depths. Each of the 15 samples was processed for particle size by using standard sieving methods (Guy, 1977). A sample was dried at $105^{\circ} \mathrm{C}$ for 24 hours (hr), weighed to determine the total mass, and split into two parts: one part was used for particle-size analysis and one part was used for soil organic content analysis. The mass of these splits ranged from 5-50 grams (g), so they were processed through a set of standard 3-inch diameter sieves to give 10 size classes $(<0.063,0.063-0.125,0.125-0.250,0.250-$ $0.500,0.5-1.0,1-2,2-4,4-8,8-16$, and 16-32 mm). Bulk density was computed from the total mass, thickness (which depended on the depth interval, and diameter of the core equal to $4.7 \mathrm{~cm}$ ). Field observations indicated that samples from the area burned by the Pozo fire had more clay and possibly more aggregates than the samples from the area burned by the Fourmile Canyon fire. Therefore, to ensure consistent treatment and to break up possible aggregates into their fundamental particle size, all samples were processed by vibrating, shaking, and gently abrading the soil in each sieve by hand rather than by using a mechanical sieve shaker. Sieved samples were weighed to nearest $0.001 \mathrm{~g}$ and the mass lost in processing the samples was typically less than 0.5 percent. The average of the three replicates for bulk density and percent of the total sample in each size class is listed in tables 1,2, and 3 for each site.

Detached soil was transported as sediment during the flume experiments. This eroded sediment $(>0.063 \mathrm{~mm})$ was collected, dried at $105^{\circ} \mathrm{C}$ for $24 \mathrm{hr}$, and reweighed. The sample was processed through the same set of 3-inch diameter sieves (without the 4-, 8-, and 16-mm sieves) to give 7 size classes. For these samples it was desired not to break up the aggregates, which represented the natural detachment form, and so the samples were not processed by hand, but by running them in a RoTap (Model RX-29, W.S.Tyler, Mentor, Ohio) sieve shaker for 10 minutes ( $\mathrm{min})$.

\section{Soil Organic Content}

Organic content was measured as loss on ignition (LOI) for the split (half of the total sample) of each of three replicates (Heiri and others, 2001). Each split sample ( 5-50 g) was put in pre-weighed porcelain crucibles and reweighed. Samples were placed in a pre-heated muffle furnace at $500^{\circ} \mathrm{C}$, removed after $2 \mathrm{hr}$, cooled in a desiccator, and reweighed to nearest $0.001 \mathrm{~g}$. The average loss of mass for the three replicates is reported as an average percent of the total loss on ignition of each split in tables 1, 2, and 3 for each site.

\section{Root Properties}

Three replicate soil samples containing roots were collected at five different depths for each cluster. Each of the 15 samples was air dried in an open sample bag in the laboratory. The dried sample was put in a 2-mm sieve and the visible roots were removed and placed in a small plastic jar. The gravel fraction $>2 \mathrm{~mm}$ was weighed. Soil aggregates containing a network of fine roots were placed in a jar with water so that the aggregates could soak up water. A lid was put on the jar and it was gently shaken, in order to separate most of the fine roots from the soil aggregates. Roots floated to the surface and were extracted. The fraction $<2 \mathrm{~mm}$ fraction was wet sieved through a $0.5-\mathrm{mm}$ sieve. Material retained in the $0.5-\mathrm{mm}$ sieve was transferred to a white enamel tray with a $5-\mathrm{mm} \times 5$ - $\mathrm{mm}$ grid drawn onto the base of the tray. Water was added to a depth of about $1 \mathrm{~cm}$, and the sample was spread uniformly across the tray. A squirt bottle was used to wash the roots off the sides and onto the water surface. A few drops of soap in the squirt bottle lowered the surface tension of water and helped reduce the clustering of roots along the edge of tray. Roots were manually extracted by using tweezers and a $10 \mathrm{X}$ magnifying lens. In some cases, it was difficult to distinguish between roots and other organic matter. All organic fragments that had a cylindrical shape with a length $>1 \mathrm{~mm}$ were treated as roots. When roots were abundant and when there was little other floating material, the roots could be extracted using a suction pipette. 
Table 1. Soil and root properties for Fourmile Canyon South site.

[vcs, very coarse sand; cs, coarse sand; ms, medium sand; fs, fine sand; vfs, very fine sand; mm, millimeter; cm centimeter; g, gram; mg, milligram; cm³, cubic centimeters; \%, percent; <, less than; no, not obtained]

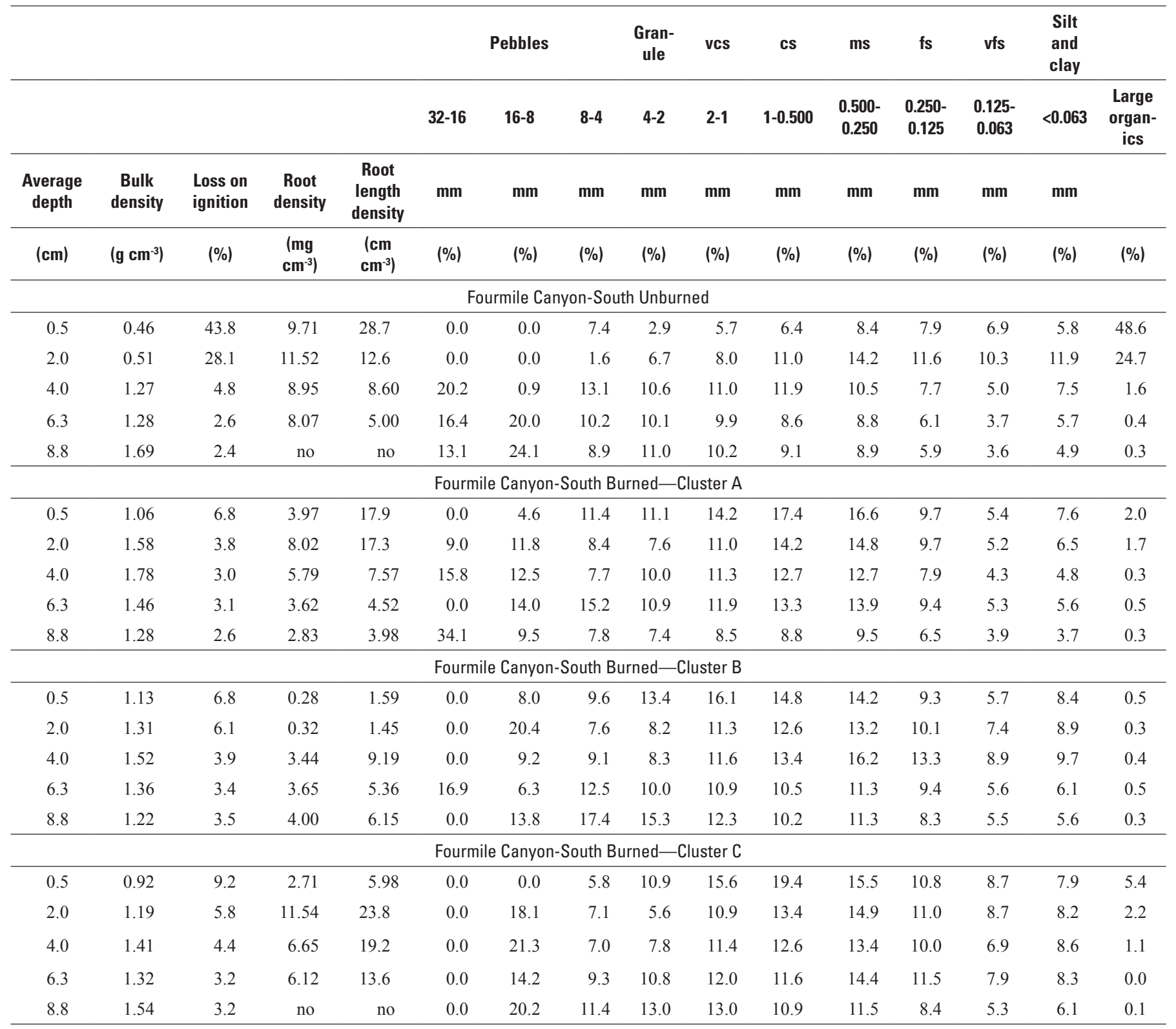


Table 2. Soil and root properties for Fourmile Canyon North site.

[vcs, very coarse sand; cs, coarse sand; ms, medium sand; fs, fine sand; vfs, very fine sand; mm, millimeter; cm centimeter; g, gram; mg, milligram; $\mathrm{cm}^{3}$, cubic centimeters; \%, percent; $<$, less than; no, not obtained]

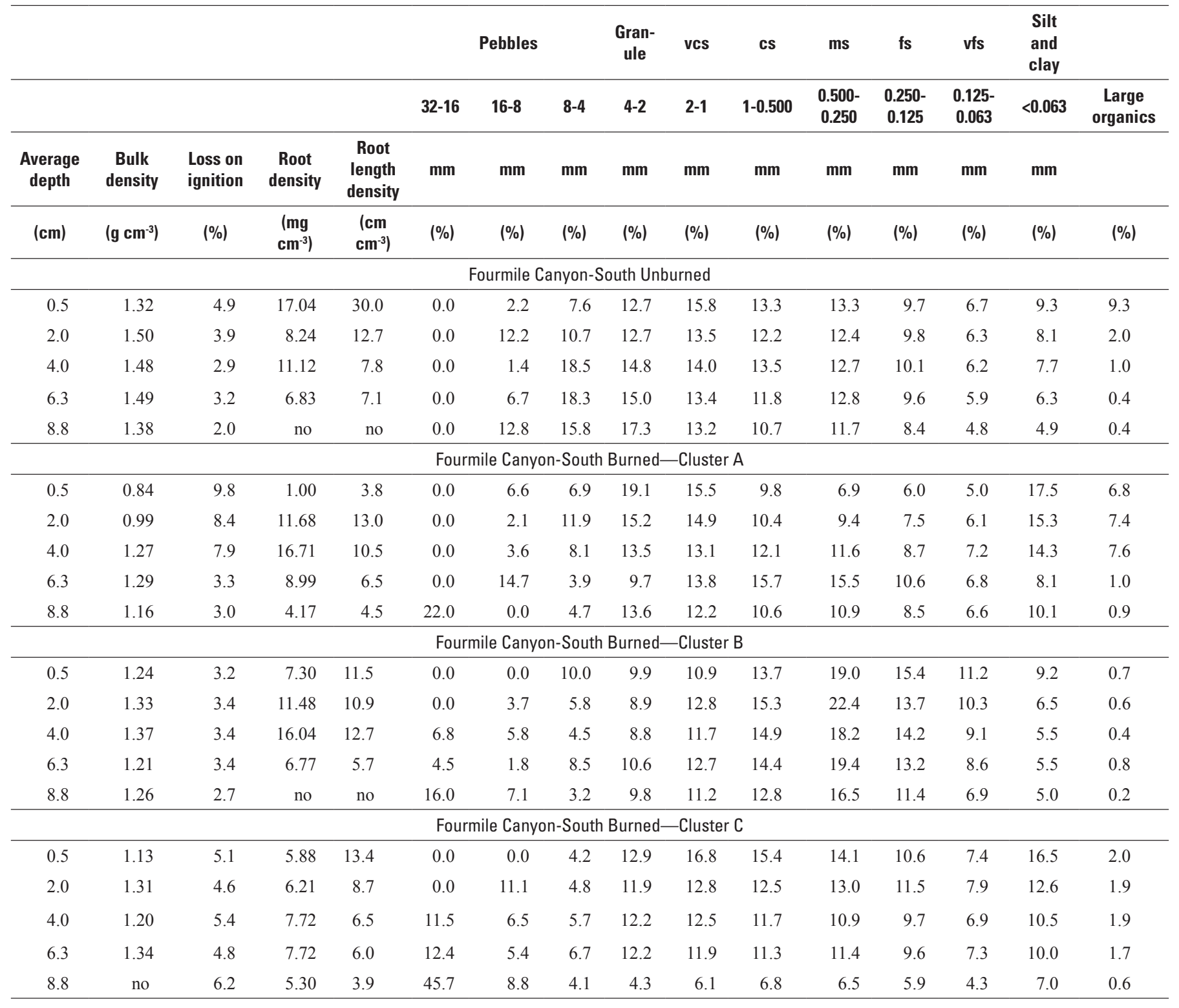


Table 3. Soil and root properties for Pozo South site.

[vcs, very coarse sand; cs, coarse sand; ms, medium sand; fs, fine sand; vfs, very fine sand; mm, millimeter; cm centimeter; g, gram; mg, milligram; $\mathrm{cm}^{3}$, cubic centimeters; $\%$, percent; $<$, less than; no, not obtained]

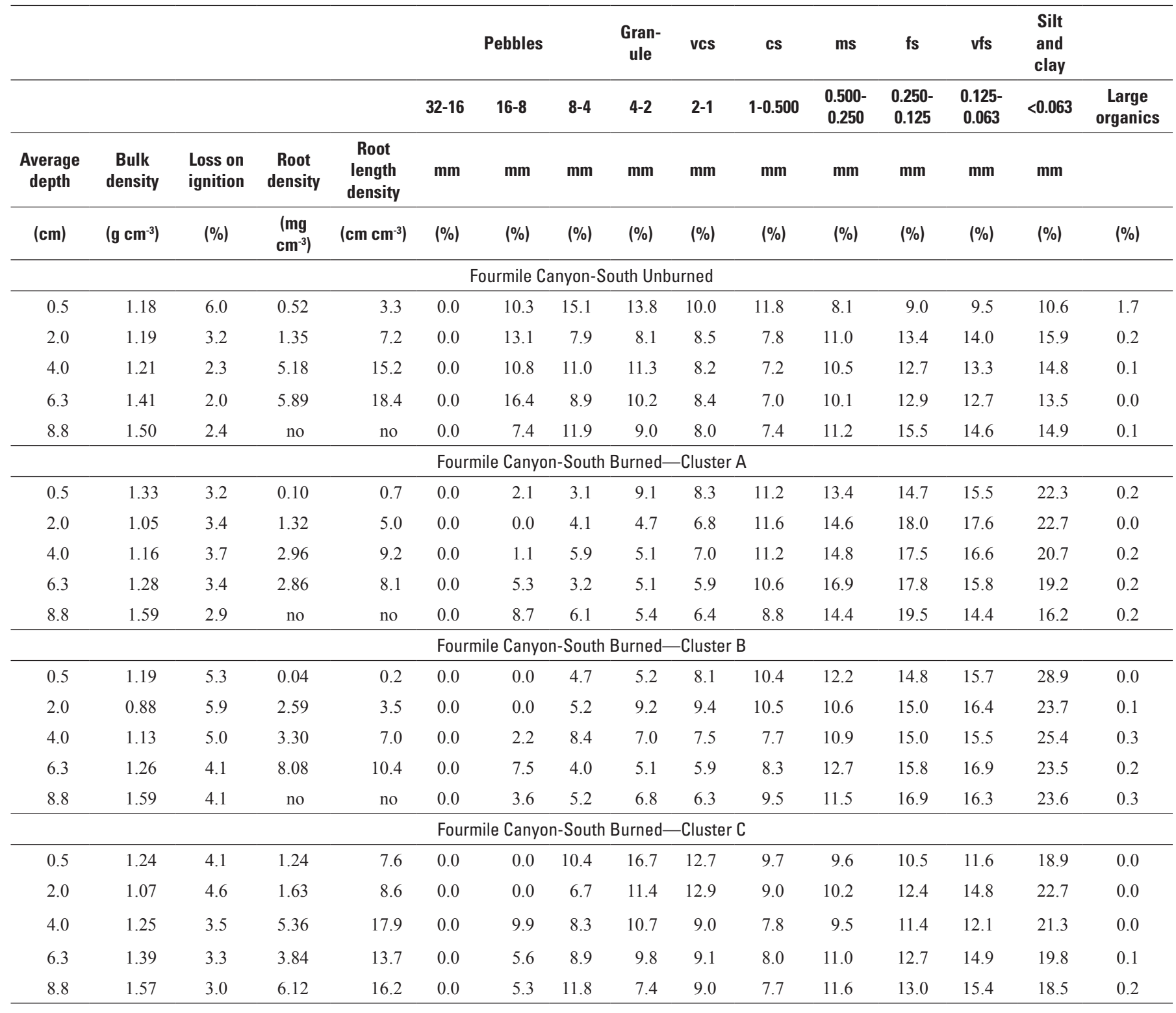


At each grid element, roots and water were sucked into the pipette, discharged from the pipette onto a small piece $(2 \mathrm{~cm} \times 1.5 \mathrm{~cm})$ of fine (approximately $1 \mathrm{~mm} \times 1 \mathrm{~mm}$ ) mesh attached to a handle, and then submerged under water in the root sample jar to release the extracted roots. This method was more time efficient but was not suitable for samples with abundant organic material which would contaminate the root sample and become a source of error in the root-mass measurements. Dead and live roots were not distinguished. However, some roots were visibly charred and possibly weakened by the fire. We rubbed the roots between our fingers and if the root rubbed onto the skin as charred material, the root was considered to be ineffective and excluded.
Root density and root-length density were measured as a function of soil depth for each site. Roots were dried in an oven at $65^{\circ} \mathrm{C}$ for $48 \mathrm{hr}$, cooled, and weighed to measure the root density $(R D)\left[\mathrm{mg} \mathrm{cm}^{-3}\right]$ (tables 1,2 , and 3$)$. Root-length density, $(R L D)\left[\mathrm{cm} \mathrm{cm}^{-3}\right]$, was measured by following the procedure outlined by Tennant (1975) using a grid method (fig. 2). The accuracy of the procedure was evaluated by comparing the grid estimation method developed by Tennant (1975) with manual root-length measurements made by using calipers. The grid-based root-length estimation performed well (coefficient of determination, $\mathrm{R}^{2}=0.998$ ) when compared to manual measurements of root lengths (fig. 3). RLD data in this report are based on the grid method (tables 1,2, and 3).
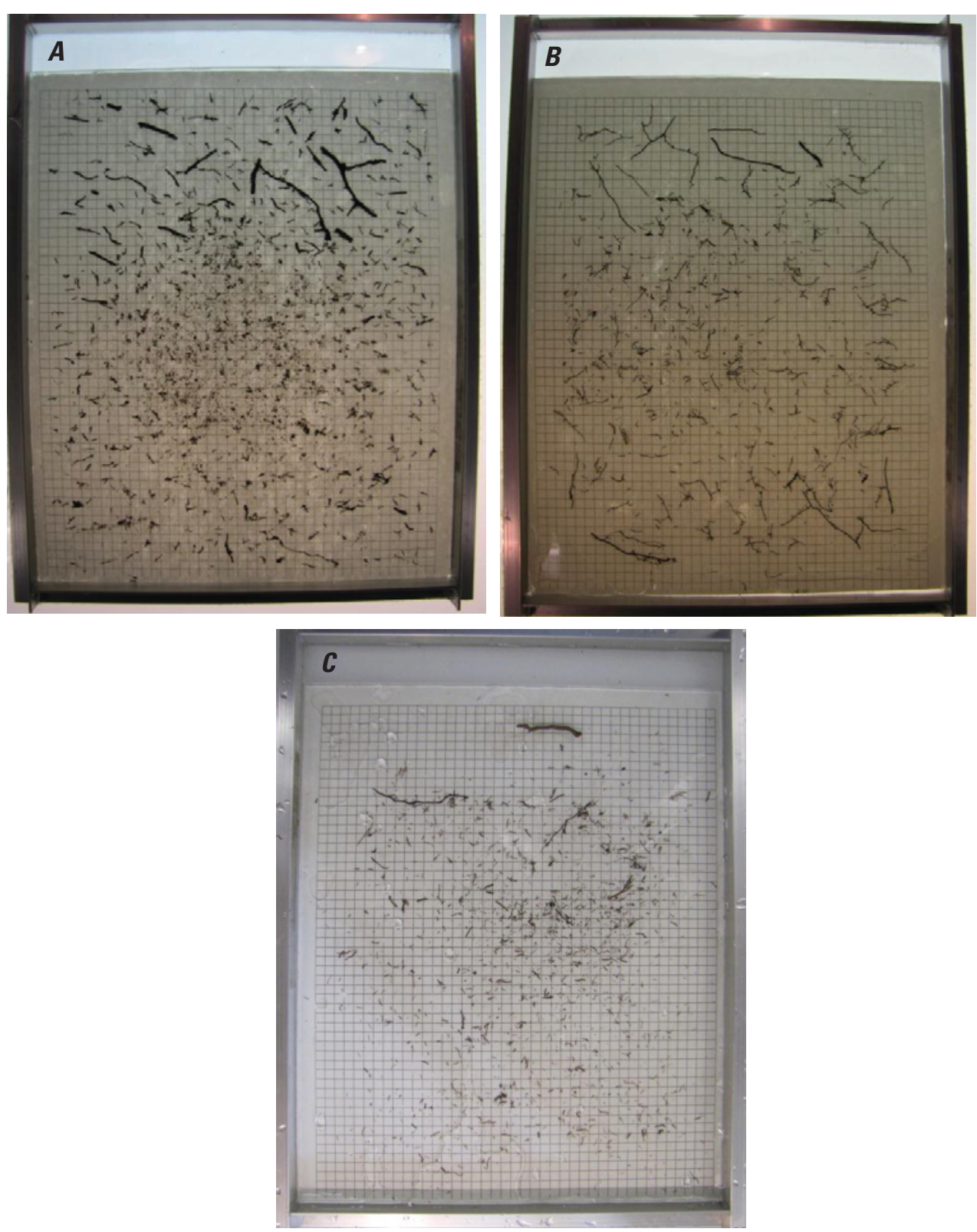

Figure 2. Extracted roots from $3-5 \mathrm{~cm}$ below the soil surface from burned sites. $A$, Fourmile Canyon-North. $B$, Fourmile Canyon-South. $C$, Pozo. The tray is $22 \mathrm{~cm}$ wide by $30 \mathrm{~cm}$ long and each grid cell is $5 \mathrm{~mm} \times 5 \mathrm{~mm}$. 


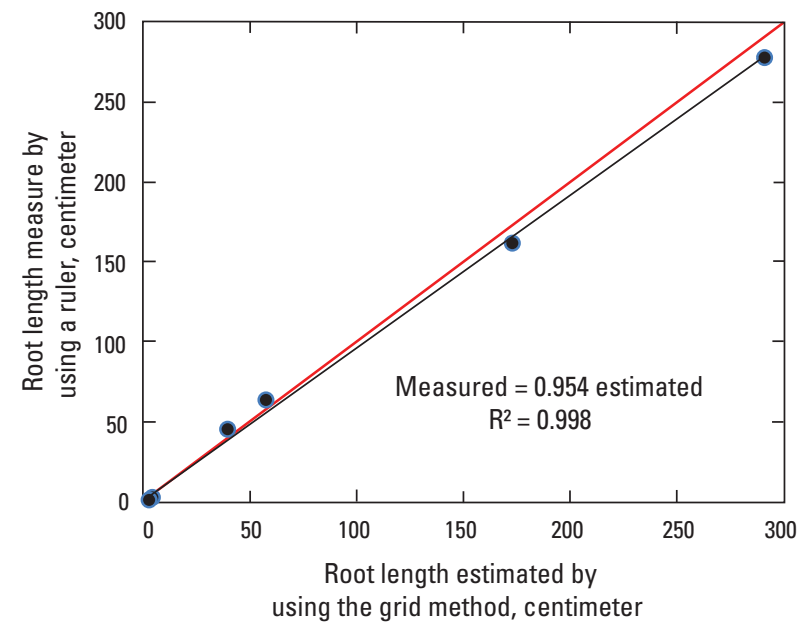

Figure 3. Calibration of the grid method of measuring root length outlined by Tennant (1975) by comparing the root lengths measured manually using metric calipers. The red line is a $1: 1$ line.

\section{Flume Properties}

The flume used to measure soil detachment rates from soil cores was a shallow-water, tilting flume. It was made of aluminum and was $10 \mathrm{~cm}$ wide and $50 \mathrm{~cm}$ long, with a maximum depth of $2.5 \mathrm{~cm}$ (fig. 4). A 5.1-cm diameter hole was cut into the $1-\mathrm{cm}$ thick aluminum bed of the flume to permit insertion of the $4.7-\mathrm{cm}$ diameter soil core $(5.1-\mathrm{cm}$ outside diameter), which was held in place by an extruder with piston mounted underneath the flume bed (fig. 4). The center of the core was $39.5 \mathrm{~cm}$ downstream from the outlet of the flow diffuser, $10.5 \mathrm{~cm}$ from the end of the flume, and $4.7 \mathrm{~cm}$ from each side wall. At the beginning of each measurement run the surface of the core could be adjusted using the extruder piston to be approximately flush with the flume bottom.

Water was not recirculated in this flume so that only clear water flowed across the soil core; thus, all the associated detachment measurements in this report are for clear water conditions. Clear water from a laboratory supply line was run into a supply tank and water was pumped from the supply tank (fig. 4C) through a 3.2-cm diameter semi-flexible plastic tubing into the head box of the flume. Discharge could be manually controlled by an inline butterfly valve from $0.02-$ $1.2 \mathrm{~L} \mathrm{~s}^{-1}$. Water left the head box through a diffuser, flowed down the flume, across the soil core, fell off the flume bottom into a $115-\mathrm{L}$ sump tank, and the water with any sediment was pumped out of the sump tank into a drain.

Flow depth was controlled by the discharge and slope of the flume bed. The flume was mounted on a box frame such that it could be tilted (by using a screw jack inside the box frame) from a horizontal to a maximum slope of about 0.80 $\left(\sim 40^{\circ}\right)$. Flow depth was measured before each run by using a point gage (accuracy: $0.005 \mathrm{~cm}$ ) mounted $7.5 \mathrm{~cm}$ upstream from the center of the core, and sometimes flow depth was measured after the run with a second point gage (accuracy:
$0.005 \mathrm{~cm}$ ) mounted $7.5 \mathrm{~cm}$ downstream from the center of the core. Discharge was computed from the measured volume ( $\sim \mathrm{L}$ with an accuracy of $\pm 10 \mathrm{~mL}$ ) collected in a bucket and the corresponding time (accuracy $\pm 0.01 \mathrm{~s}$ ) to fill the bucket. Discharge in this type of flume is not a linear function of depth at all slopes (fig. 5). The relation is non-linear for slopes less than $<0.08$ and linear for slopes $>0.08$. Slopes used in the detachment experiments ranged from 0.053-0.177 (tables 4-6; between solid black lines in fig. 5). Typical flow conditions in the flume (with a smooth plug inserted in the hole for the soil cores) were supercritical with Froude number (Dingman, 1984) increasing with slope from about 1 to 4, Reynolds number (Dingman, 1984) ranging from about $1.8 \times 10^{2}$ to $1.2 \times 10^{4}$, and Darcy-Weisbach friction factor (Dingman, 1984) ranging from $0.05-0.4$.

\section{Boundary Shear Stress}

While the flow in the flume was steady, it was not uniform. Generally, the water accelerated down the flume without any soil cores in place and varied between accelerating and decelerating with a soil core in place depending on the surface roughness of the soil. For uniform flow the shear stress, $\tau$ [dynes $\mathrm{cm}^{-2}$ ] would simply be the product of water depth, $h$ $[\mathrm{cm}]$, and flume slope, $S$ [non-dimensional] or

$$
\tau=\rho g h S
$$

where

$$
\begin{aligned}
& \mathrm{r}\left[\mathrm{g} \mathrm{cm}^{-3}\right] \quad \begin{array}{l}
\text { is density of water, and } \\
\mathrm{g}
\end{array} \\
& \text { is acceleration of gravity } \\
& \left(980 \mathrm{~cm} \mathrm{~s}^{-2}\right) .
\end{aligned}
$$

For accelerated flow, two terms must be added that represent the shear stress caused by change in mean velocity and change in pressure between two points (Julien, 1998). If $h_{1}[\mathrm{~cm}], h_{2}[\mathrm{~cm}], U_{1}\left[\mathrm{~cm} \mathrm{~s}^{-1}\right]$, and $U_{2}\left[\mathrm{~cm} \mathrm{~s}^{-1}\right]$ are the water depths and mean cross-sectional velocities at points 1 and 2 separated by a distance, $d[\mathrm{~cm}]$, then the non-uniform shear stress is given by:

$$
\left.\left.\tau_{N}=\rho h\left[g S+\left(U_{1}+U_{2}\right) / 2\right)\left(U_{1}-U_{2}\right) / d+\left(h_{1}+h_{2}\right) / 2\right)\left(h_{1}-h_{2}\right) / d\right]
$$

Non-uniform shear stresses were measured for smooth flume conditions and compared to non-uniform values corresponding to many different soil surface conditions. Initially, a suitable range of target shear stresses $(16,31,95$, and 182 dynes $\mathrm{cm}^{-2}$ ) were selected for the flume experiments and combinations of flume slope and water depth were calculated that would give these values of uniform shear stresses $(0.053,0.30$ $\mathrm{cm} ; 0.053,0.60 \mathrm{~cm} ; 0.088,0.110 \mathrm{~cm}$; and $0.177 ; 0.105 \mathrm{~cm}$; see tables 4-6). The flume (with a smooth plug in the hole for the soil core) was run with these combinations to determine the non-uniform shear stresses $(22,63,144$, and 421 dynes 

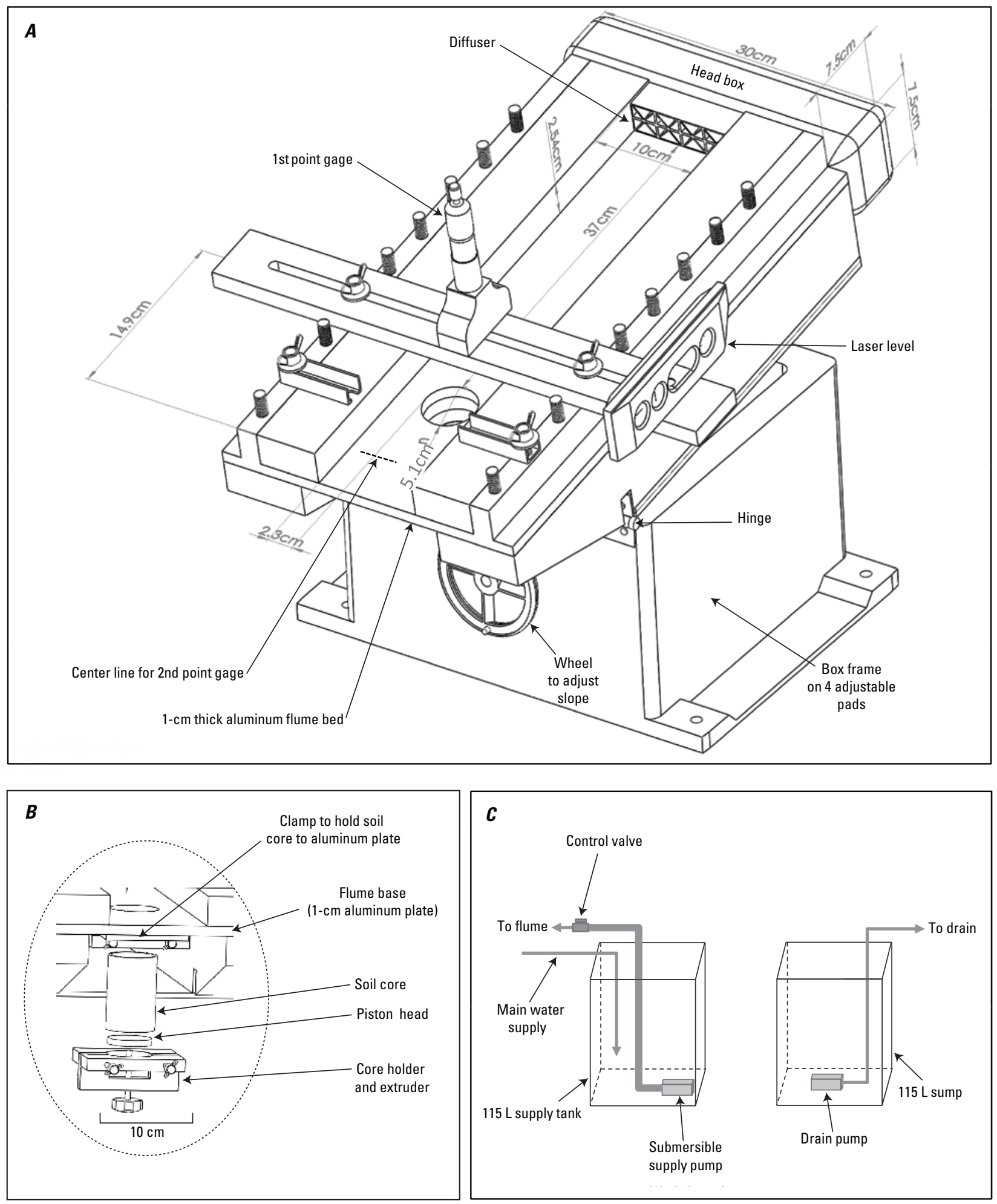

Figure 4. A, Diagram of shallow-water tilting flume and circulation system. $B$, Core attachment. $C$, water circulation system. Diagrams prepared by Graeme Scheuber. 


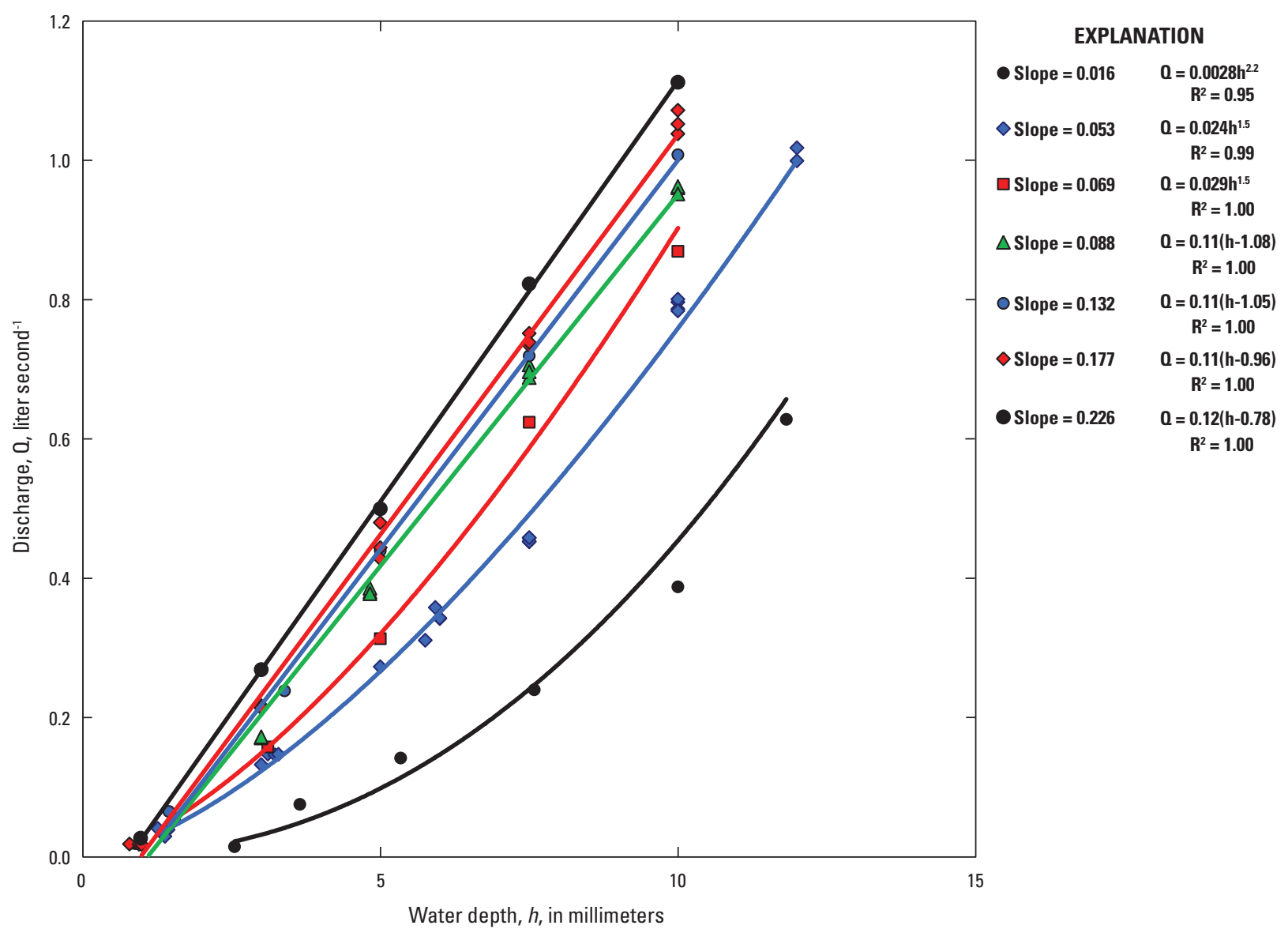

Figure 5. Relations between water discharge and water depth, at different slopes, for the shallow-water tilting flume.

$\mathrm{cm}^{-2}$ ) under smooth conditions. The non-uniform shear stress was then periodically checked during actual conditions with different soil cores in the flume. Water depth was always set to a predetermined depth at the upstream point gage before each experimental run, but it was not possible to measure the water depth at the downstream point gage while collecting the sediment during the actual experimental run. Therefore, after a set of 3 runs (for a given depth below the surface of the core) a separate run was made without collecting sediment and the second depth was measured.

Mean velocities were computed from the two depths, width of the flume $(10 \mathrm{~cm})$, and the measured discharge, and $\tau_{\mathrm{N}}$ was computed for the condition with a soil core in place. The range of $\tau_{\mathrm{N}}$ measured in the flume with different roughness conditions of the soil surface bracketed the values measured for the smooth flume conditions (fig. 6). There were $42,40,39$, and 37 measurements corresponding to $22,63,144$, and 421 dynes $\mathrm{cm}^{-2}$, respectively. Linear regression of the average shear stress values for rough conditions with a soil core in place, $\tau_{N}^{r}$, versus those for smooth conditions, $\tau_{N}^{s}$, gave $\tau_{N}^{r}$ $=0.98 \tau_{N}^{s}\left(\mathrm{R}^{2}=0.99\right)$ with coefficient of variations for the four shear stresses $\left(22,63,144\right.$, and 421 dynes $\left.\mathrm{cm}^{-2}\right)$ used in the experiments that were $0.21,0.27,0.25$, and 0.18 , respectively.

\section{Stream Power}

Stream power can be expressed as either a power per unit bed area or power per unit weight. Stream power is the rate that energy or work is supplied to the flow by converting potential energy into kinetic energy (Bagnold, 1966; Yang, 1972). For a unit length of flow, $l[\mathrm{~cm}]$, the decrease in height is $l S[\mathrm{~cm}]$, the force per unit time is $\rho g Q$ [dyne $\mathrm{s}^{-1}$ or erg $\mathrm{cm}^{-1}$ $\mathrm{s}^{-1}$, and the stream power per unit length, $\Omega\left[\mathrm{erg} \mathrm{s}^{-1} \mathrm{~cm}^{-1}\right.$, was given by Bagnold (1966) as:

$$
\Omega=\rho g Q S
$$

Stream power per unit area or unit stream power,

$\omega_{a}$ [erg s $\left.\mathrm{cm}^{-1}\right]$, is $\Omega$ divided by the flow width or

$$
\omega_{a}=\rho g d U S=\tau U
$$

where

$$
U \quad \text { is the cross-sectional mean velocity. }
$$

Unit stream power can also be expressed as power per unit weight of water if the flow is assumed to be steady and 
uniform (Yang, 1972). The equation for this unit stream power, $\omega_{\mathrm{w}}\left[\mathrm{cm} \mathrm{s}^{-1}\right]$ was given by Yang (1972) as:

$$
\omega_{\mathrm{w}}=U S
$$

Flow in the tilting flume is non-uniform, so values of $\omega_{a}$ are listed in tables 4-6 as non-uniform unit stream power.

\section{Soil Detachment Measurements}

Each individual core provided five measurements for one value of shear stress at five different depths, which corresponded approximately to the midpoint of soil sampling intervals $(0.5,2,4$, and $6.25 \mathrm{~cm})$. A second core was used for measurements for a different shear-stress value at five depths. Thus, soil detachment was measured at all four shear stresses by using four cores from a cluster. The fifth core collected in a cluster was archived in a refrigerator. Each burned site had three clusters, which provided three replicate measurements for each shear stress.

Two types of experimental runs were carried out to measure the soil detachment as a function of depth below the surface of the soil-a short run and a long run. For both runs, a soil core was mounted in the extruder (fig. 4B), and then attached to the underside of the flume so that the soil surface in the core was flush with the bed of the flume, which was set to the desired slope. Water drops were placed on the surface to qualitatively assess the water repellency, other physical and visual characteristics were recorded, and then the soil core was covered with a protective cover (piece of sheet metal) to prevent erosion while the desired flow depth (that would produce the required shear stress) was established by using the manual control valve (fig. 4C).

For a short run, once flow conditions were steady, the protective cover was removed and a bucket was simultaneously placed under the water falling off the end of the flume and a timer was started. Approximately $4 \mathrm{~L}$ of water was collected in the bucket and the timer was stopped as was the flow in the flume. The water in the bucket was poured through a $0.063-\mathrm{mm}$ sieve, set inside a funnel, with the funnel's spout inside a 4-L graduated cylinder to measure the volume. The volume was recorded and then poured into a churn splitter (14-L, Bel-Arts Products, Wayne, New Jersey). The piston was advanced until 50 percent of the soil surface topography was again flush with the bed of the flume, the depth below the surface of the soil was recorded, the protective cover was replaced, and the flow restarted. The process was then repeated two more times to give a composite sample consisting of three short runs. After the third short run, the sediment in the 0.063$\mathrm{mm}$ sieve was transferred into pre-weighed aluminum tray, dried at $105^{\circ} \mathrm{C}$ for $24 \mathrm{hr}$, and reweighed (accuracy $0.001 \mathrm{~g}$ ) to determine the mass of the $>0.063-\mathrm{mm}$ fraction. A subsample (400-500 mL) of water and sediment was withdrawn from the churn splitter, filtered through two, pre-weighed 0.45 -micrometer $(\mu \mathrm{m})$ membrane filters (HAWP04700, Millipore Ireland
Ltd., Billerica, Massachusetts), dried at $105^{\circ} \mathrm{C}$ for one hour, and reweighed (after being in a desiccator for $15 \mathrm{~min}$ ) to determine the mass of the $<0.063-\mathrm{mm}$ fraction.

If the soil was non-cohesive and could be eroded, then the flowing water was used to erode the core down to the next desired depth and the process for three short runs described above was repeated. If the water could not erode the soil material, then the core was advanced by using the piston until just below the desired depth, and the core was cut manually by using scissors to cut root material and a thin piece of sheet metal to slice through the soil material. The soil surface was flushed twice with approximately $400 \mathrm{~mL}$ surge of water lasting 1-2 s, and then extruded a short distance until the surface topography was flush with the flume bed. Because the soil had been disturbed by cutting, a series of two short runs followed by a separate long run was used to measure the soil detachment.

A long run was carried out after collecting separate composite samples ( $>0.063$-mm and $<0.063$-mm fractions) consisting of two short runs described above. For the long run, after removing the protective cover, a $0.063-\mathrm{mm}$ sieve was inserted into the flow for $1 \mathrm{~min}$, and at some point during this time interval, the bucket was held briefly (3-20 s) under the water coming through the sieve to collect $\sim 4 \mathrm{~L}$ of sediment and water in order to determine the discharge and to obtain a sample of sediment $<0.063 \mathrm{~mm}$. This sample was poured directly into a 4-L churn splitter (4-L, Bel-Arts Products), subsampled $(\sim 400-500 \mathrm{~mL})$, and filtered through another set of two, pre-weighed $0.45-\mu \mathrm{m}$ membrane filters to determine a mass of the $<0.063-\mathrm{mm}$ fraction for the long run. The $>0.063-\mathrm{mm}$ fraction, in the $0.063-\mathrm{mm}$ sieve, was processed as described above, but was put in a separate aluminum tray and labeled as a long run. The long run is thought to be a better measurement of the soil detachment after the disturbance caused by cutting the core.

For the initial experiments, the short runs were physically combined with the long runs and then weighed to determine the total detachment rate (values in italics in tables 4-6). For later experiments, the short and long runs were weighed separately, the detachment rates were calculated separately, and then combined mathematically to determine the total detachment rate. To estimate the detachment rates for the initial long runs in the initial experiments, correlation equations were developed for the $>0.063 \mathrm{~mm}$ and the $<0.063 \mathrm{~mm}$ fractions by plotting the values for long run from the later experiments (values in bold font in tables 4-6) versus the mathematically combined short and long runs for the same experiments. Power laws were found to be the best fit for the $>0.063-\mathrm{mm}$ data because equal weight was given to small and large values that spanned 3-4 orders of magnitude. Linear relations with intercept equal to zero were found to best fit for the $<0.063$-mm data because the range of values was less than those for the $>0.063-\mathrm{mm}$ fraction, and there were numerous zero values (essentially below the resolution of the measurement method), which the $>0.063-\mathrm{mm}$ fraction did not have, and thus, the $<0.063$-mm data could not be fitted to a power law. The 
Table 4. Hydrologic parameters and sedimentologic results for soil core samples collected at the Fourmile Canyon South site:

[Diameter of core $=4.7 \mathrm{~cm}$; width of flume $=10 \mathrm{~cm}$; distance between upstream and downstream water depths $=14.9 \mathrm{~cm}$; distance downstream was only measured on 3rd run at a given core depth after a long run; italics, short runs were combined with a long run and then weighed; bold, long run; bold italics, long run was estimated from regression equations 6-11 given in the text; $\mathrm{s}$, seconds; $\mathrm{cm}$, centimeter; $\mathrm{mm}$, millimeter; $\mathrm{cm}^{-2}$, square centimeter; $\mathrm{mL}$, milliliter; $\mathrm{g}$, gram; $>$, greater than; < less than; SB, sample code; $\mathrm{nm}$, not measured]

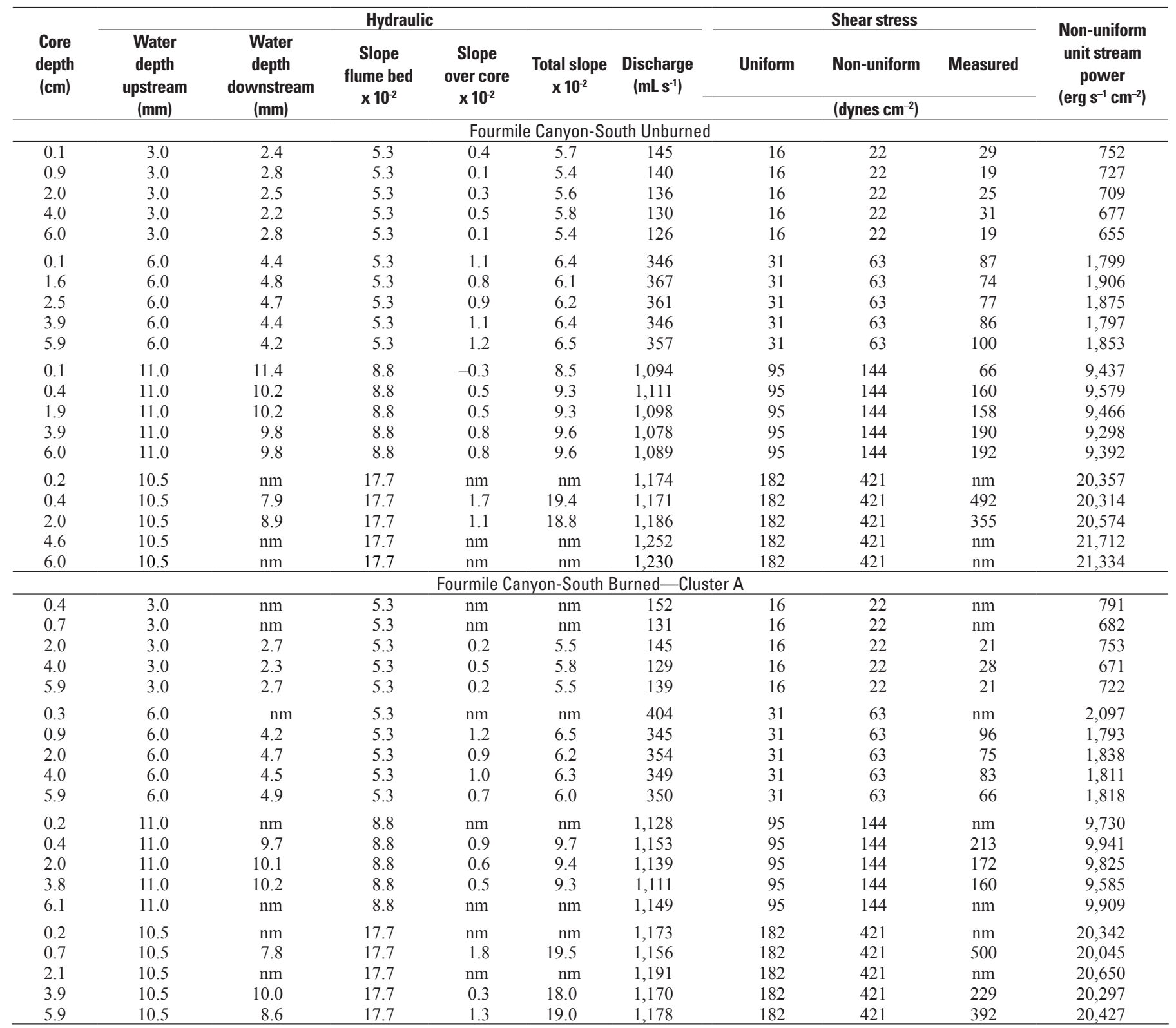


Table 4. Hydrologic parameters and sedimentologic results for soil core samples collected at the Fourmile Canyon South site.-Continued

[Diameter of core $=4.7 \mathrm{~cm}$; width of flume $=10 \mathrm{~cm}$; distance between upstream and downstream water depths $=14.9 \mathrm{~cm}$; distance downstream was only measured on 3rd run at a given core depth after a long run; italics, short runs were combined with a long run and then weighed; bold, long run; bold italics, long run was estimated from regression equations 6-11 given in the text; $\mathrm{s}$, seconds; $\mathrm{cm}$, centimeter; $\mathrm{mm}$, millimeter; $\mathrm{cm}^{-2}$, square centimeter; mL, milliliter; g, gram; $>$, greater than; < less than; SB, sample code; $\mathrm{nm}$, not measured]

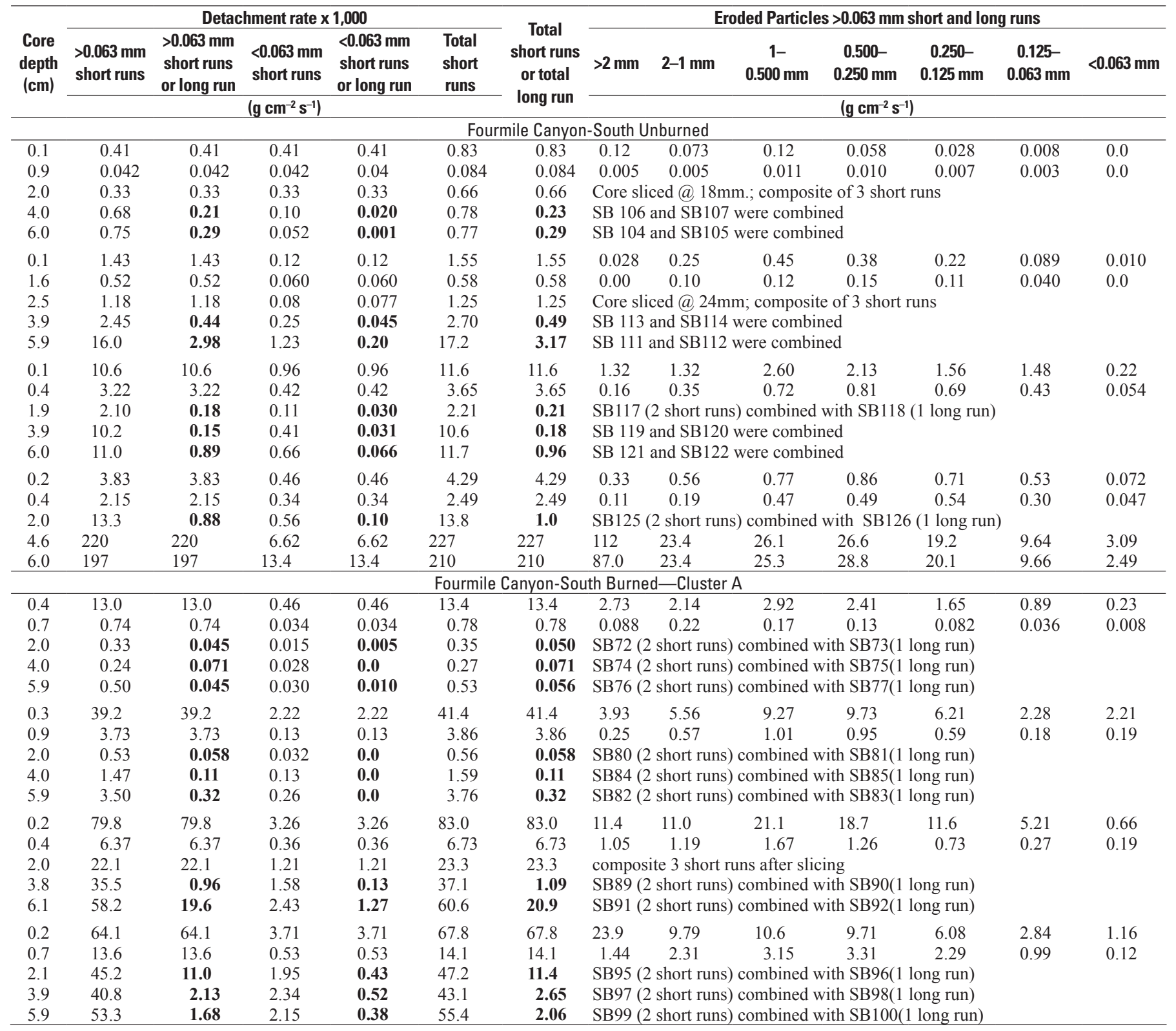


Table 4. Hydrologic parameters and sedimentologic results for soil core samples collected at the Fourmile Canyon South site.—Continued

[Diameter of core $=4.7 \mathrm{~cm}$; width of flume $=10 \mathrm{~cm}$; distance between upstream and downstream water depths $=14.9 \mathrm{~cm}$; distance downstream was only measured on 3rd run at a given core depth after a long run; italics, short runs were combined with a long run and then weighed; bold, long run; bold italics, long run was estimated from regression equations $6-11$ given in the text; $\mathrm{s}$, seconds; $\mathrm{cm}$, centimeter; $\mathrm{mm}$, millimeter; $\mathrm{cm}^{-2}$, square centimeter; $\mathrm{mL}$, milliliter; $\mathrm{g}$, gram; $>$, greater than; < less than; SB, sample code; nm, not measured]

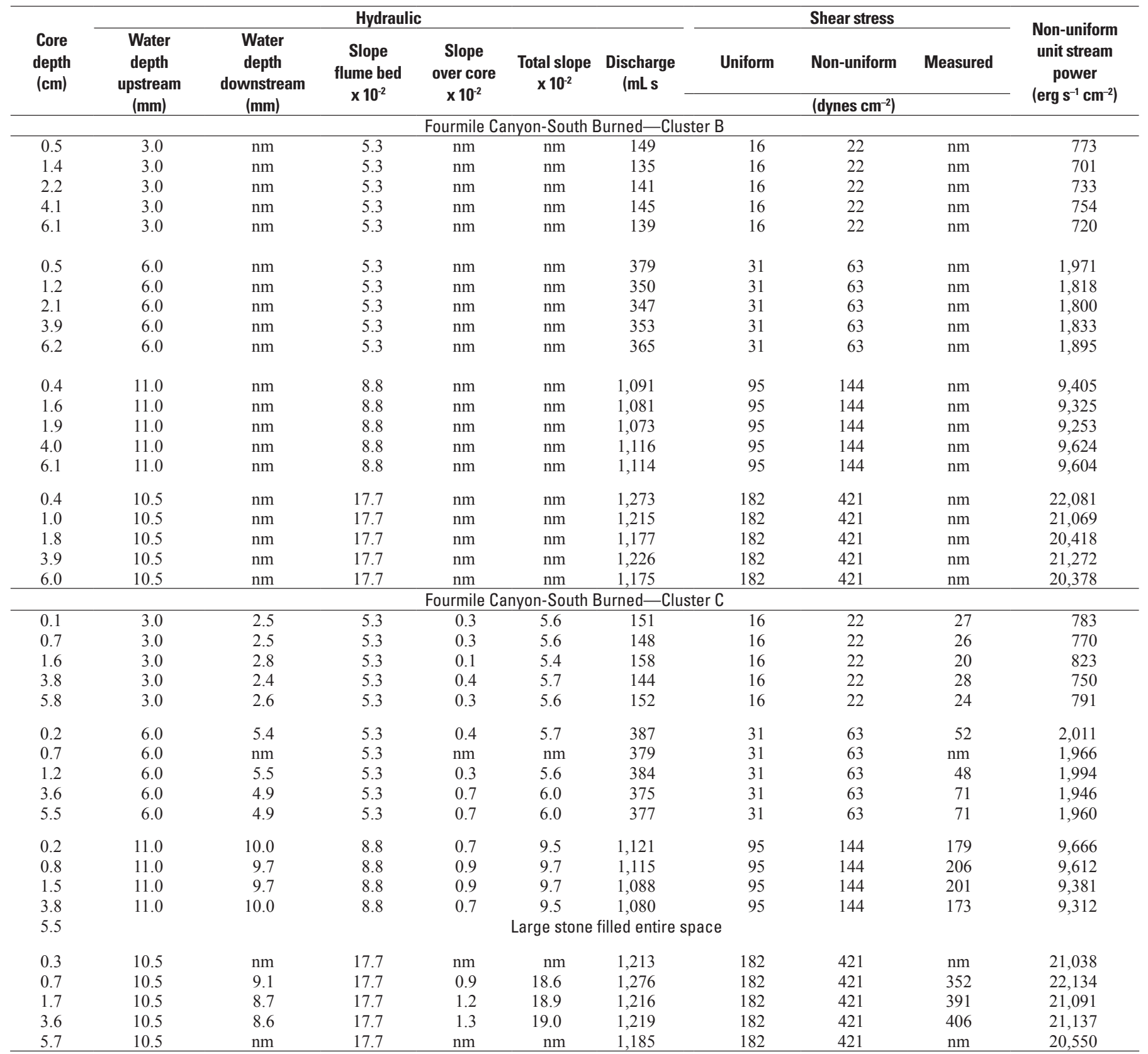


Table 4. Hydrologic parameters and sedimentologic results for soil core samples collected at the Fourmile Canyon South site.-Continued

[Diameter of core $=4.7 \mathrm{~cm}$; width of flume $=10 \mathrm{~cm}$; distance between upstream and downstream water depths $=14.9 \mathrm{~cm}$; distance downstream was only measured on 3rd run at a given core depth after a long run; italics, short runs were combined with a long run and then weighed; bold, long run; bold italics, long run was estimated from regression equations 6-11 given in the text; $\mathrm{s}$, seconds; $\mathrm{cm}$, centimeter; $\mathrm{mm}$, millimeter; $\mathrm{cm}^{-2}$, square centimeter; mL, milliliter; g, gram; $>$, greater than; < less than; SB, sample code; $\mathrm{nm}$, not measured]

\begin{tabular}{|c|c|c|c|c|c|c|c|c|c|c|c|c|c|}
\hline \multirow{3}{*}{$\begin{array}{l}\text { Core } \\
\text { depth } \\
\text { (cm) }\end{array}$} & \multicolumn{5}{|c|}{ Detachment rate $\times 1,000$} & \multirow{3}{*}{$\begin{array}{c}\text { Total } \\
\text { short runs } \\
\text { or total } \\
\text { long run }\end{array}$} & \multicolumn{7}{|c|}{ Eroded Particles $>0.063 \mathrm{~mm}$ short and long runs } \\
\hline & \multirow[t]{2}{*}{$\begin{array}{l}>0.063 \mathrm{~mm} \\
\text { short runs }\end{array}$} & \multirow{2}{*}{$\begin{array}{l}>0.063 \mathrm{~mm} \\
\text { short runs } \\
\text { or long run }\end{array}$} & $\begin{array}{l}<0.063 \mathrm{~mm} \\
\text { short runs }\end{array}$ & \multirow[t]{2}{*}{$\begin{array}{l}<0.063 \mathrm{~mm} \\
\text { short runs } \\
\text { or long run }\end{array}$} & \multirow[t]{2}{*}{$\begin{array}{l}\text { Total } \\
\text { short } \\
\text { runs }\end{array}$} & & \multirow[t]{2}{*}{$>2 \mathrm{~mm}$} & \multirow[t]{2}{*}{ 2-1 mm } & \multirow[t]{2}{*}{$\begin{array}{c}1- \\
0.500 \mathrm{~mm}\end{array}$} & \multirow{2}{*}{$\begin{array}{c}0.500- \\
0.250 \mathrm{~mm}\end{array}$} & \multirow[t]{2}{*}{$\begin{array}{c}0.250- \\
0.125 \mathrm{~mm}\end{array}$} & \multirow[t]{2}{*}{$\begin{array}{c}0.125- \\
0.063 \mathrm{~mm}\end{array}$} & \multirow[t]{2}{*}{$<0.063 \mathrm{~mm}$} \\
\hline & & & $\left(\mathrm{g} \mathrm{cm}^{-2} \mathrm{~s}^{-1}\right)$ & & & & & & & & & & \\
\hline 0.5 & 52.8 & 52.8 & 2.51 & 2.51 & 55.3 & 55.3 & 7.70 & 10.6 & 12.3 & 10.2 & 6.80 & 3.84 & 1.24 \\
\hline 1.4 & 4.54 & 4.54 & 0.26 & 0.26 & 4.8 & 4.80 & 0.67 & 0.74 & 1.04 & 0.91 & 0.67 & 0.39 & 0.13 \\
\hline 2.2 & 0.45 & 0.16 & 0.035 & 0.022 & 0.49 & 0.18 & \multicolumn{7}{|c|}{ composite 2 short +1 long runs no cutting mentioned } \\
\hline 0.5 & 75.9 & 75.9 & 2.84 & 2.84 & 78.8 & 78.8 & 34.6 & 9.17 & 9.41 & 9.66 & 7.40 & 3.41 & 2.26 \\
\hline 1.2 & 10.21 & 10.21 & 0.97 & 0.97 & 11.2 & 11.18 & 0.41 & 1.16 & 2.02 & 2.53 & 2.33 & 1.25 & 0.52 \\
\hline 2.1 & 1.45 & 0.53 & 0.14 & 0.087 & 1.59 & 0.61 & \multicolumn{7}{|c|}{ composite 2 short +1 long runs no cutting mentioned } \\
\hline 3.9 & 0.81 & 0.29 & 0.13 & 0.085 & 0.94 & 0.37 & compo & ite 2 short & 1 long runs & no cutting $n$ & nentioned & & \\
\hline 6.2 & 4.57 & 1.74 & 0.63 & 0.394 & 5.20 & 2.13 & compo & ite 2 short & 1 long runs & no cutting $n$ & hentioned & & \\
\hline 6.1 & 142 & 61.9 & 5.47 & 3.45 & 148 & 65.4 & compo & ite of $3 \mathrm{shc}$ & t runs; slice & at $58 \mathrm{~mm}$ & & & \\
\hline 0.4 & 122 & 122 & 3.26 & 3.26 & 125 & 125 & 13.0 & 27.8 & 32.2 & 22.1 & 17.6 & 8.18 & 0.61 \\
\hline 1.0 & 1.72 & 1.72 & 0.43 & 0.43 & 2.1 & 2.15 & 0.55 & 0.19 & 0.27 & 0.31 & 0.25 & 0.11 & 0.05 \\
\hline 1.8 & 0.37 & 0.13 & 0.025 & 0.016 & 0.39 & 0.14 & compo & ite 2 short & 1 long runs & sliced at $\sim$ & $20 \mathrm{~mm}$ & & \\
\hline 3.9 & 10.2 & 4.00 & 0.69 & 0.44 & 10.9 & 4.44 & compo & ite 2 short & 1 long runs & sliced at $\sim$ & $20 \mathrm{~mm}$ & & \\
\hline 6.0 & 229 & 102 & 8.02 & 5.05 & 238 & 107 & compo & site 2 short & 1 long runs & no slicing 1 & nentioned & & \\
\hline & & & & & Fourmil & Canyon-So & th Burn & $\mathrm{d}$-Cluste & & & & & \\
\hline 0.1 & 3.74 & 3.74 & 0.062 & 0.062 & 3.81 & 3.81 & 1.31 & 0.91 & 0.71 & 0.46 & 0.25 & 0.08 & 0.035 \\
\hline 0.7 & 1.57 & 1.57 & 0.10 & 0.10 & 1.66 & 1.66 & 0.25 & 0.26 & 0.32 & 0.28 & 0.24 & 0.17 & 0.034 \\
\hline 1.6 & 0.93 & 0.93 & 0.071 & 0.071 & 1.00 & 1.00 & 0.24 & 0.11 & 0.18 & 0.19 & 0.11 & 0.067 & 0.016 \\
\hline 3.8 & 0.89 & 0.39 & 0.10 & 0.041 & 0.99 & 0.43 & 0.11 & 0.018 & 0.050 & 0.10 & 0.081 & 0.037 & 0.002 \\
\hline 5.8 & 2.04 & 0.56 & 0.11 & 0.049 & 2.15 & 0.61 & 0.10 & 0.12 & 0.074 & 0.10 & 0.090 & 0.044 & 0.027 \\
\hline 5.5 & & & rge stone fill & ed entire sp & & & & & & & & & \\
\hline 0.3 & 56.2 & 56.2 & 1.15 & 1.1 & 57.3 & 57.3 & 14.5 & 12.9 & 12.0 & 8.8 & 5.3 & 2.3 & 0.4 \\
\hline 0.7 & 17.7 & 17.7 & 0.60 & 0.60 & 18.3 & 18.3 & 6.7 & 2.7 & 2.5 & 2.6 & 1.8 & 1.1 & 0.4 \\
\hline 1.7 & 5.18 & 0.39 & 0.35 & 0.0 & 5.53 & 0.39 & 0.0 & 0.024 & 0.073 & 0.12 & 0.10 & 0.061 & 0.007 \\
\hline 3.6 & 10.0 & 0.74 & 0.17 & 0.0 & 10.20 & 0.74 & 0.085 & 0.050 & 0.15 & 0.21 & 0.15 & 0.066 & 0.031 \\
\hline 5.7 & 318 & & 3.53 & & 322 & & No lon & run, pebb & dislodged & eating seve & re scour & & \\
\hline
\end{tabular}


Table 5. Hydrologic parameters and sedimentologic results for soil core samples collected at the Fourmile Canyon North site:

[Diameter of core $=4.7 \mathrm{~cm}$; width of flume $=10 \mathrm{~cm}$; distance between upstream and downstream water depths $=14.9 \mathrm{~cm}$; distance downstream was only measured on 3rd run at a given core depth after a long run; italics, short runs were combined with a long run and then weighed; bold, long run; bold italics, long run was estimated from regression equations 6-11 given in the text; $\mathrm{s}$, seconds; $\mathrm{cm}$, centimeter; $\mathrm{mm}$, millimeter; $\mathrm{cm}^{-2}$, square centimeter; mL, milliliter; $\mathrm{g}$, gram; $>$, greater than; < less than; SB, sample code; nm, not measured]

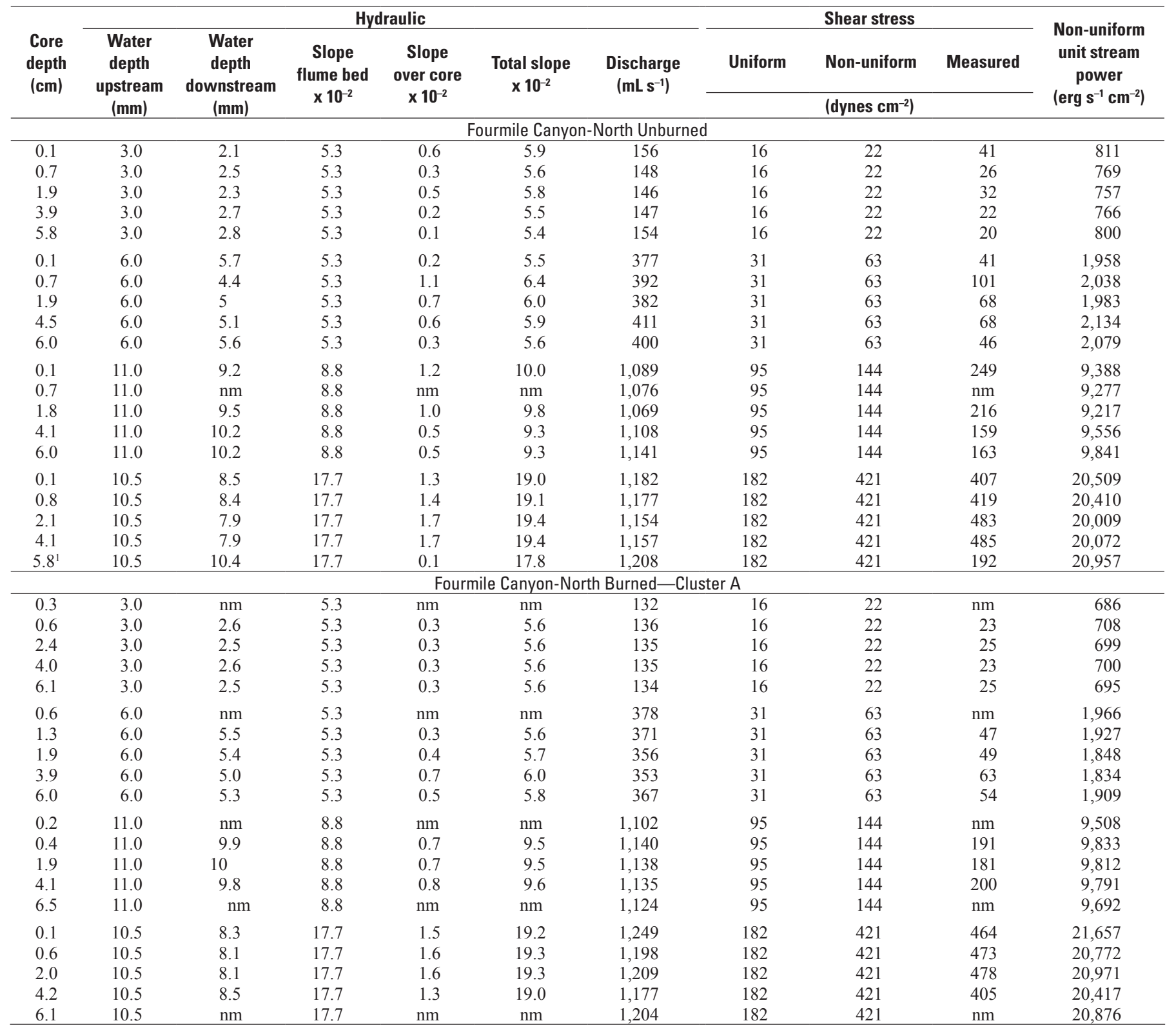


Table 5. Hydrologic parameters and sedimentologic results for soil core samples collected at the Fourmile Canyon North site.-Continued

[Diameter of core $=4.7 \mathrm{~cm}$; width of flume $=10 \mathrm{~cm}$; distance between upstream and downstream water depths $=14.9 \mathrm{~cm}$; distance downstream was only measured on 3rd run at a given core depth after a long run; italics, short runs were combined with a long run and then weighed; bold, long run; bold italics, long run was estimated from regression equations 6-11 given in the text; $\mathrm{s}$, seconds; $\mathrm{cm}$, centimeter; $\mathrm{mm}$, millimeter; $\mathrm{cm}^{-2}$, square centimeter; mL, milliliter; g, gram; $>$, greater than; < less than; SB, sample code; $\mathrm{nm}$, not measured]

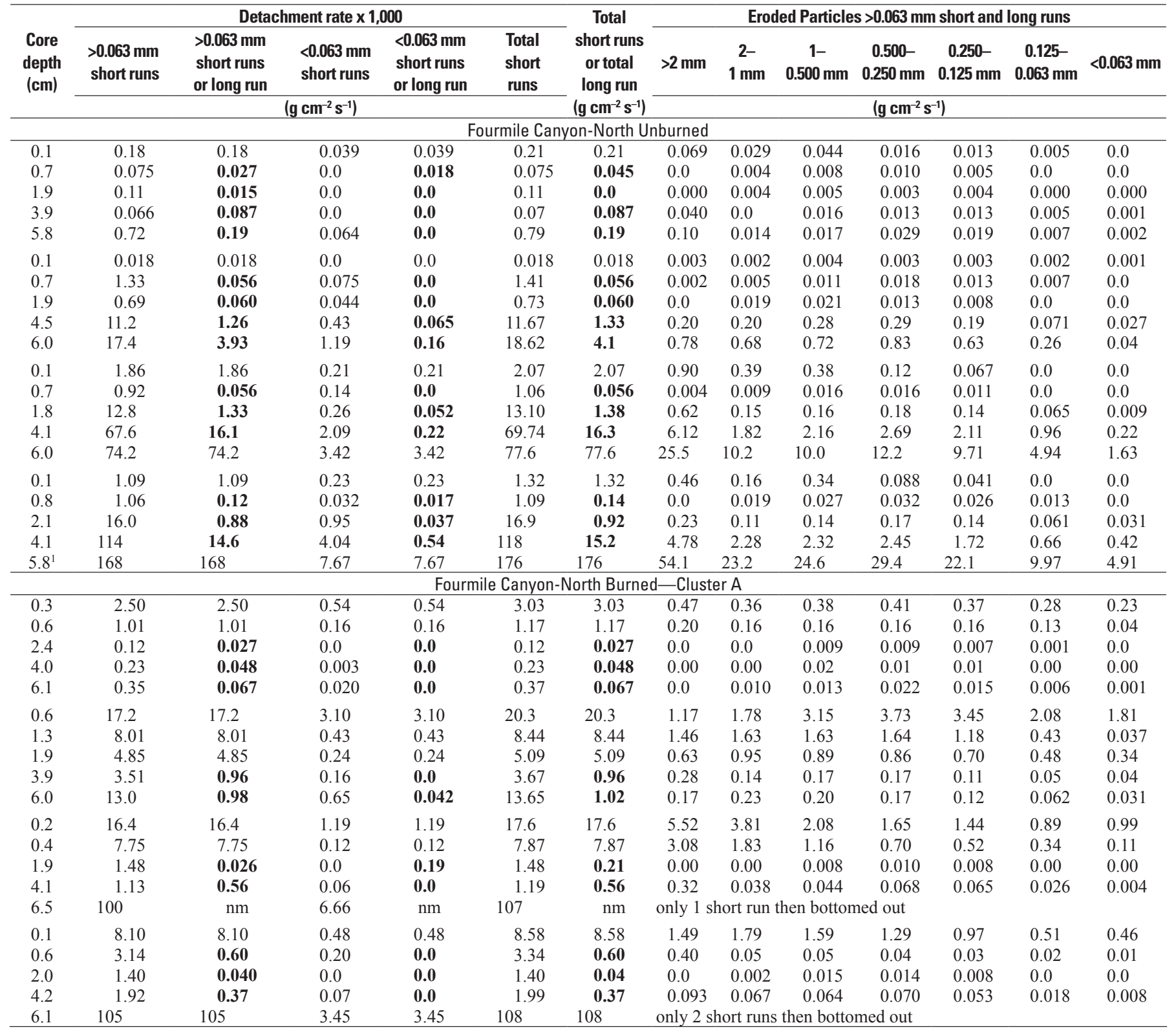


Table 5. Hydrologic parameters and sedimentologic results for soil core samples collected at the Fourmile Canyon North site.-Continued

[Diameter of core $=4.7 \mathrm{~cm}$; width of flume $=10 \mathrm{~cm}$; distance between upstream and downstream water depths $=14.9 \mathrm{~cm}$; distance downstream was only measured on 3rd run at a given core depth after a long run; italics, short runs were combined with a long run and then weighed; bold, long run; bold italics, long run was estimated from regression equations $6-11$ given in the text; s, seconds; $\mathrm{cm}$, centimeter; $\mathrm{mm}$, millimeter; $\mathrm{cm}^{-2}$, square centimeter; mL, milliliter; $\mathrm{g}$, gram; $>$, greater than; < less than; SB, sample code; nm, not measured]

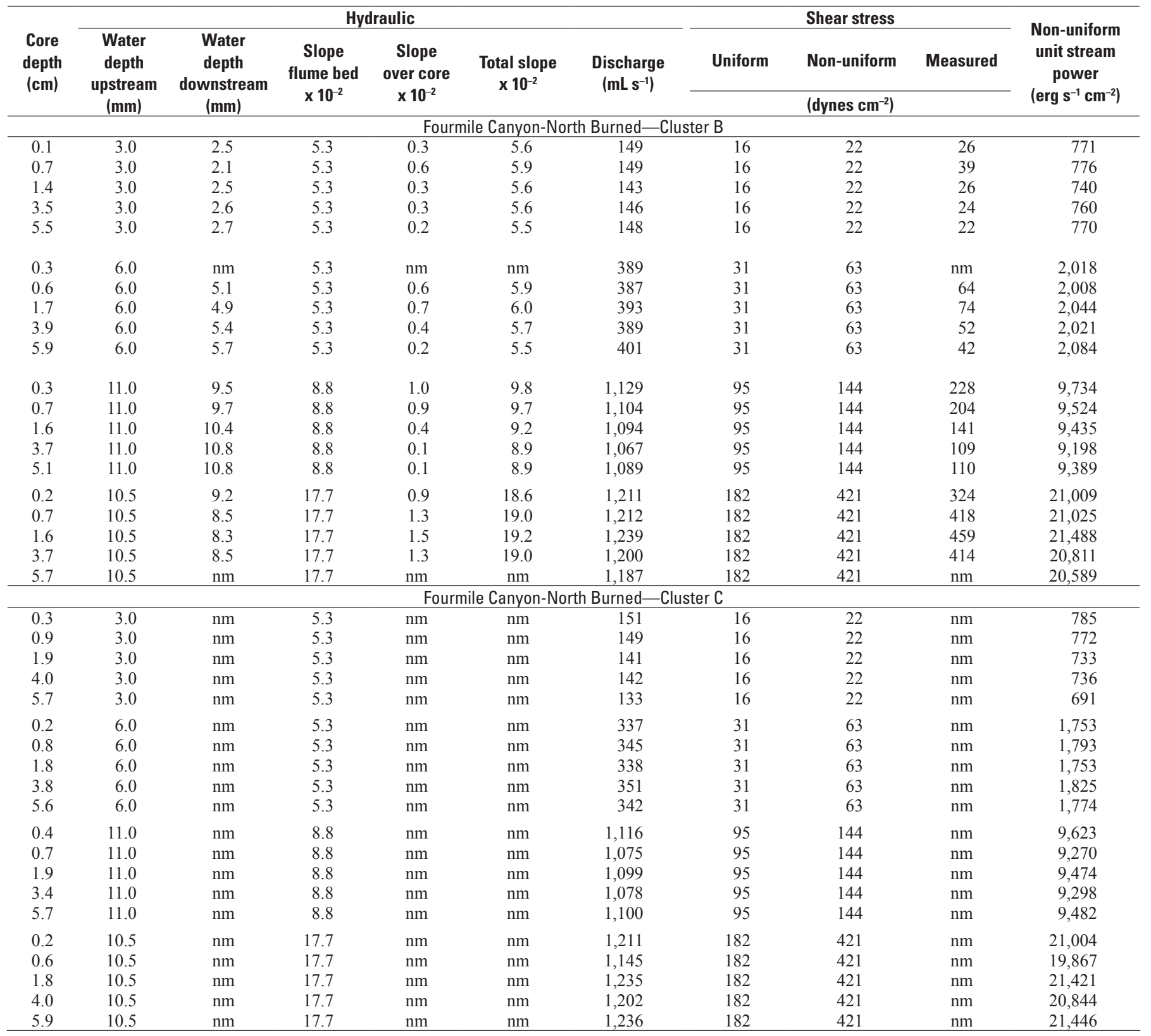


Table 5. Hydrologic parameters and sedimentologic results for soil core samples collected at the Fourmile Canyon North site.-Continued

[Diameter of core $=4.7 \mathrm{~cm}$; width of flume $=10 \mathrm{~cm}$; distance between upstream and downstream water depths $=14.9 \mathrm{~cm}$; distance downstream was only measured on 3rd run at a given core depth after a long run; italics, short runs were combined with a long run and then weighed; bold, long run; bold italics, long run was estimated from regression equations 6-11 given in the text; $\mathrm{s}$, seconds; $\mathrm{cm}$, centimeter; $\mathrm{mm}$, millimeter; $\mathrm{cm}^{-2}$, square centimeter; mL, milliliter; g, gram; $>$, greater than; < less than; SB, sample code; nm, not measured]

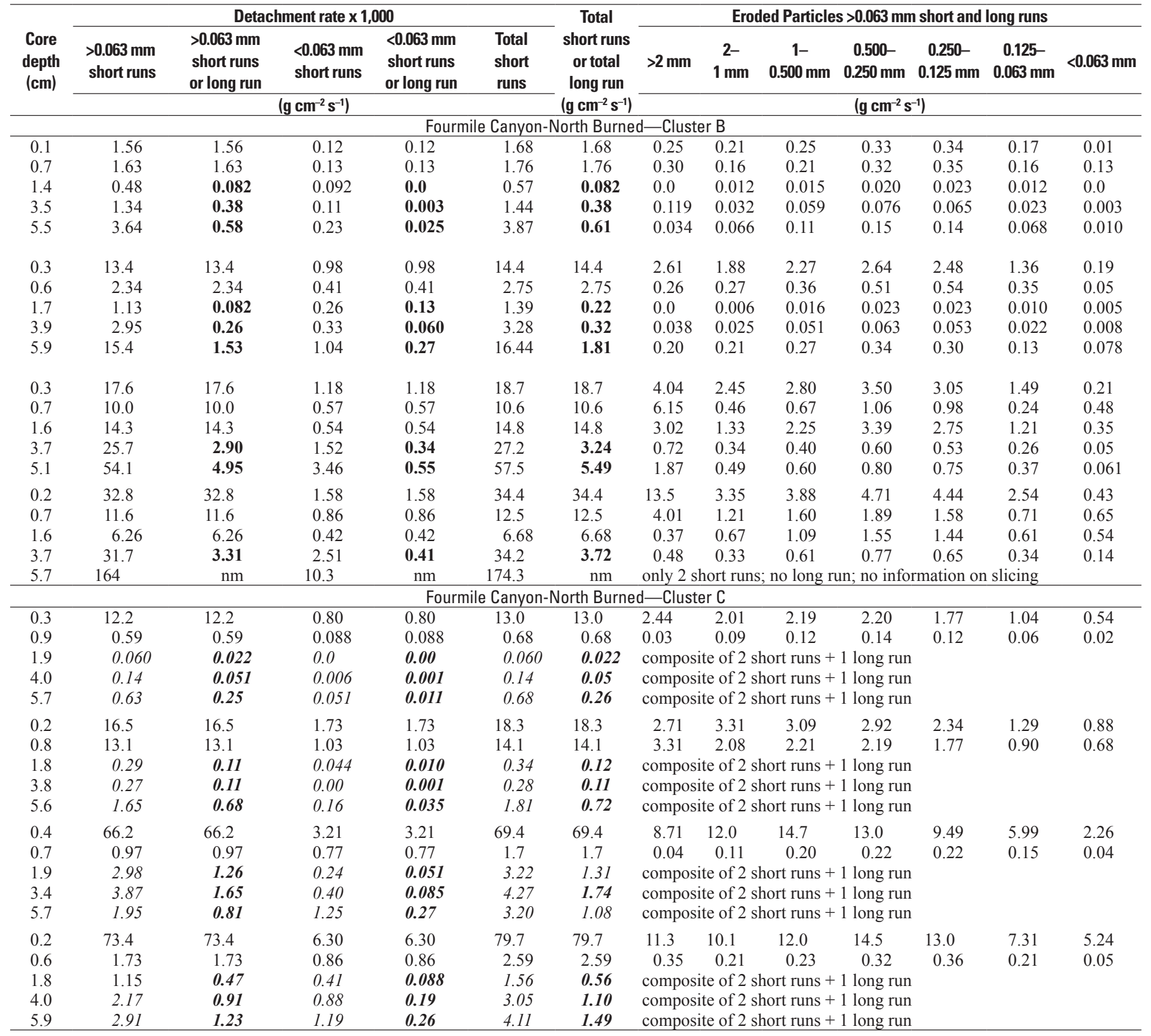

${ }^{1}$ Not cut, no long run. 
Table 6. Hydrologic parameters and sedimentologic results for soil core samples collected at the Pozo Sout

[Diameter of core $=4.7 \mathrm{~cm}$; width of flume $=10 \mathrm{~cm}$; distance between upstream and downstream water depths $=14.9 \mathrm{~cm}$; distance downstream was only measured on 3rd run at a given core depth after a long run; italics, short runs were combined with a long run and then weighed; bold, long run; bold italics, long run was estimated from regression equations $6-11$ given in the text; $\mathrm{s}$, seconds; $\mathrm{cm}$, centimeter; $\mathrm{mm}$, millimeter; $\mathrm{cm}^{-2}$, square centimeter; $\mathrm{mL}$, milliliter; g, gram; $>$, greater than; < less than; SB, sample code; $\mathrm{nm}$, not measured]

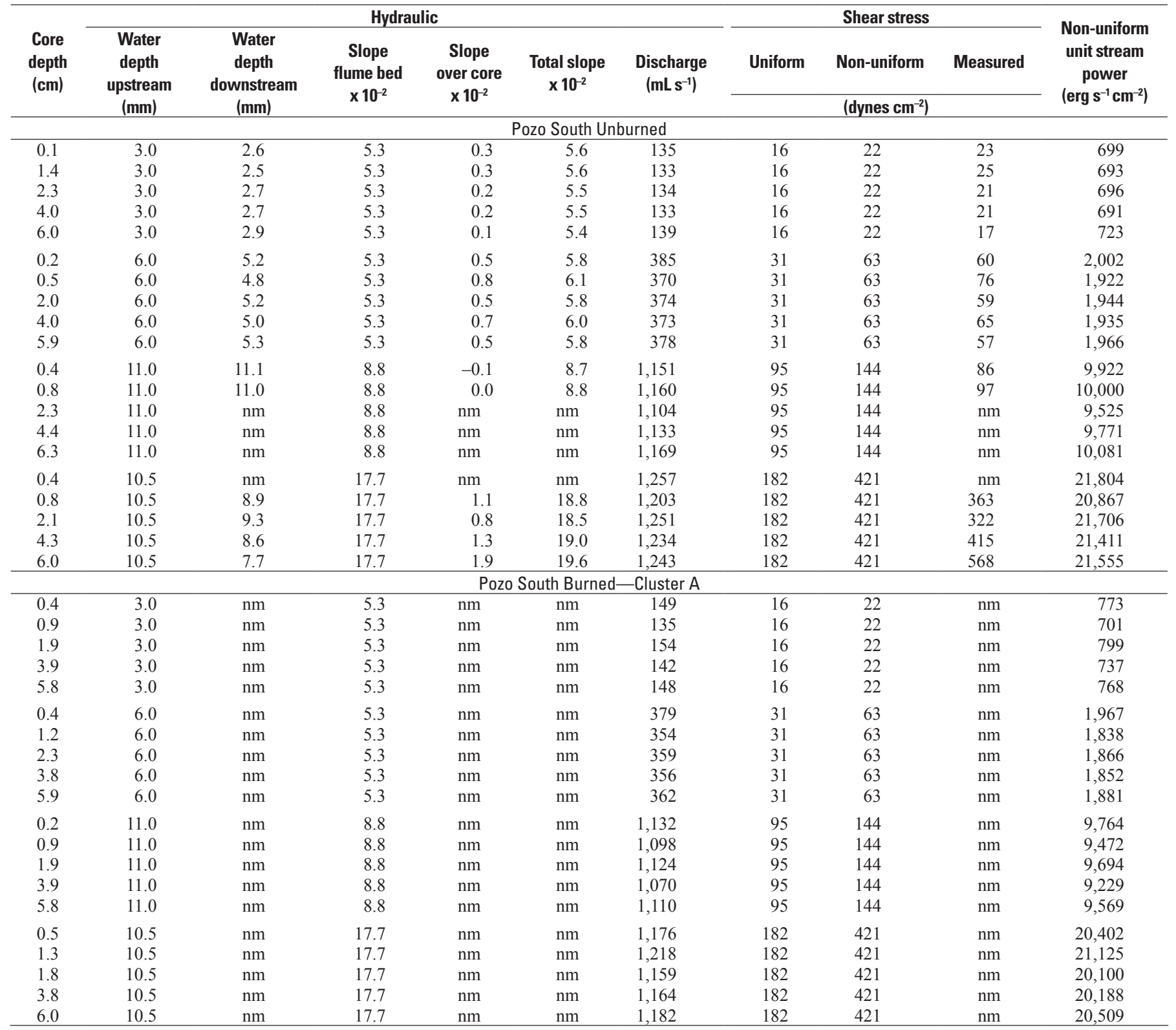


Table 6. Hydrologic parameters and sedimentologic results for soil core samples collected at the Pozo South site.—Continued

[Diameter of core $=4.7 \mathrm{~cm}$; width of flume $=10 \mathrm{~cm}$; distance between upstream and downstream water depths $=14.9 \mathrm{~cm}$; distance downstream was only measured on 3rd run at a given core depth after a long run; italics, short runs were combined with a long run and then weighed; bold, long run; bold italics, long run was estimated from regression equations 6-11 given in the text; $\mathrm{s}$, seconds; $\mathrm{cm}$, centimeter; $\mathrm{mm}$, millimeter; $\mathrm{cm}^{-2}$, square centimeter; $\mathrm{mL}$, milliliter; $\mathrm{g}$, gram; $>$, greater than; < less than; SB, sample code; $\mathrm{nm}$, not measured]

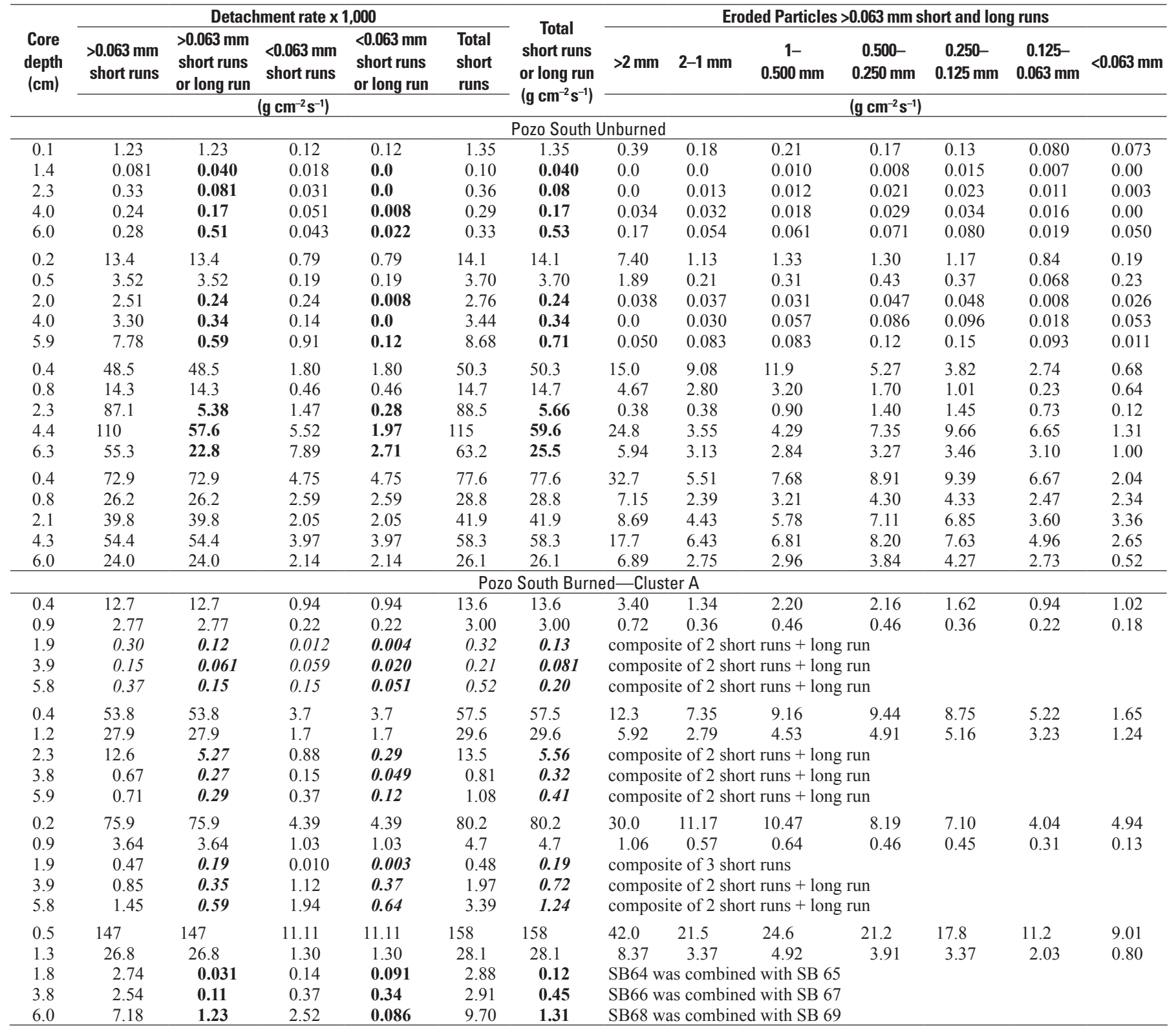


Table 6. Hydrologic parameters and sedimentologic results for soil core samples collected at the Pozo South site.—Continued

[Diameter of core $=4.7 \mathrm{~cm}$; width of flume $=10 \mathrm{~cm}$; distance between upstream and downstream water depths $=14.9 \mathrm{~cm}$; distance downstream was only measured on 3rd run at a given core depth after a long run; italics, short runs were combined with a long run and then weighed; bold, long run; bold italics, long run was estimated from regression equations 6-11 given in the text; $\mathrm{s}$, seconds; $\mathrm{cm}$, centimeter; $\mathrm{mm}$, millimeter; $\mathrm{cm}^{-2}$, square centimeter; $\mathrm{mL}$, milliliter; $\mathrm{g}$, gram; $>$, greater than; < less than; SB, sample code; $\mathrm{nm}$, not measured]

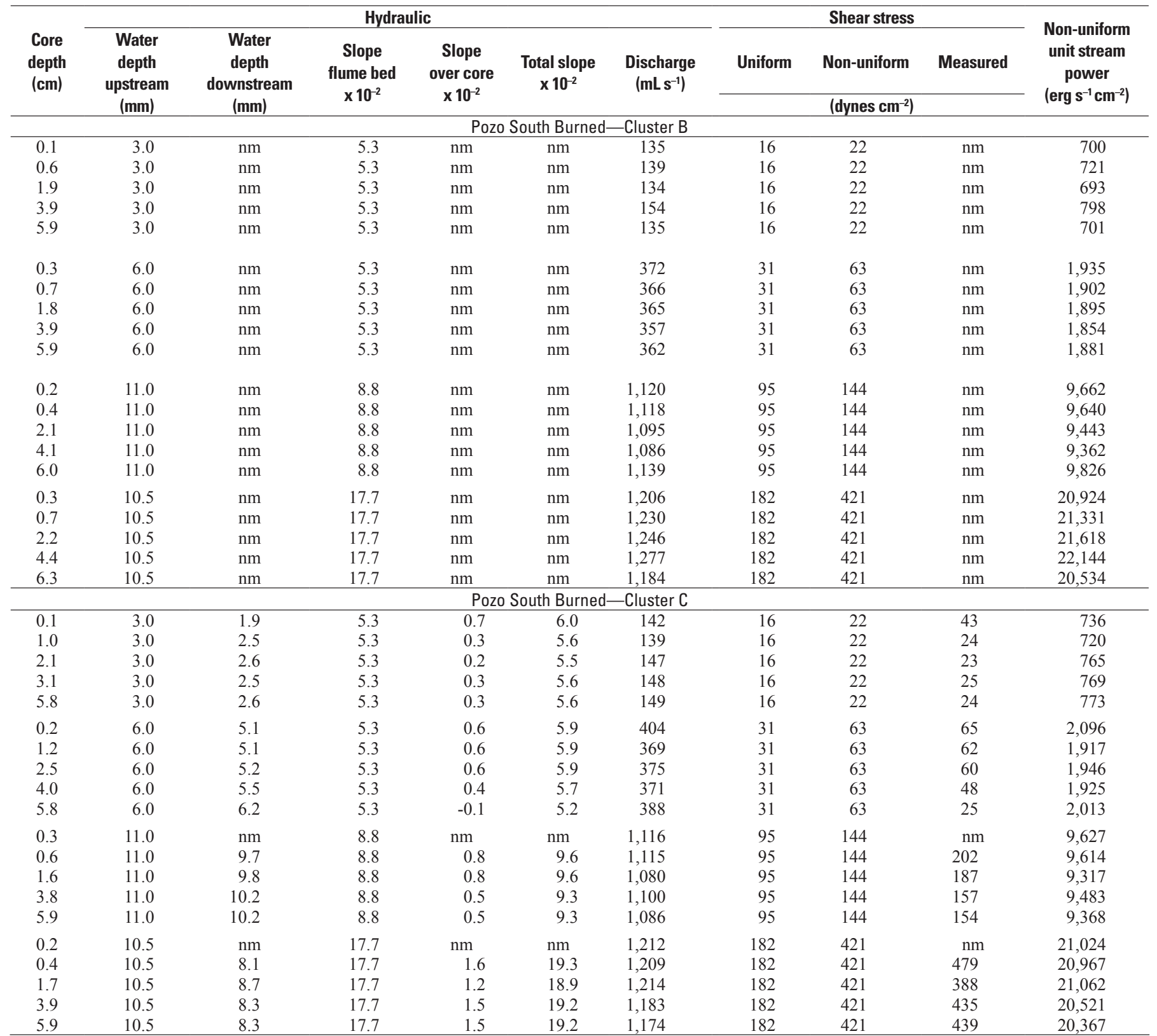


Table 6. Hydrologic parameters and sedimentologic results for soil core samples collected at the Pozo South site.—Continued

[Diameter of core $=4.7 \mathrm{~cm}$; width of flume $=10 \mathrm{~cm}$; distance between upstream and downstream water depths $=14.9 \mathrm{~cm}$; distance downstream was only measured on 3rd run at a given core depth after a long run; italics, short runs were combined with a long run and then weighed; bold, long run; bold italics, long run was estimated from regression equations 6-11 given in the text; $\mathrm{s}$, seconds; $\mathrm{cm}$, centimeter; $\mathrm{mm}$, millimeter; $\mathrm{cm}^{-2}$, square centimeter; mL, milliliter; g, gram; $>$, greater than; < less than; SB, sample code; $\mathrm{nm}$, not measured]

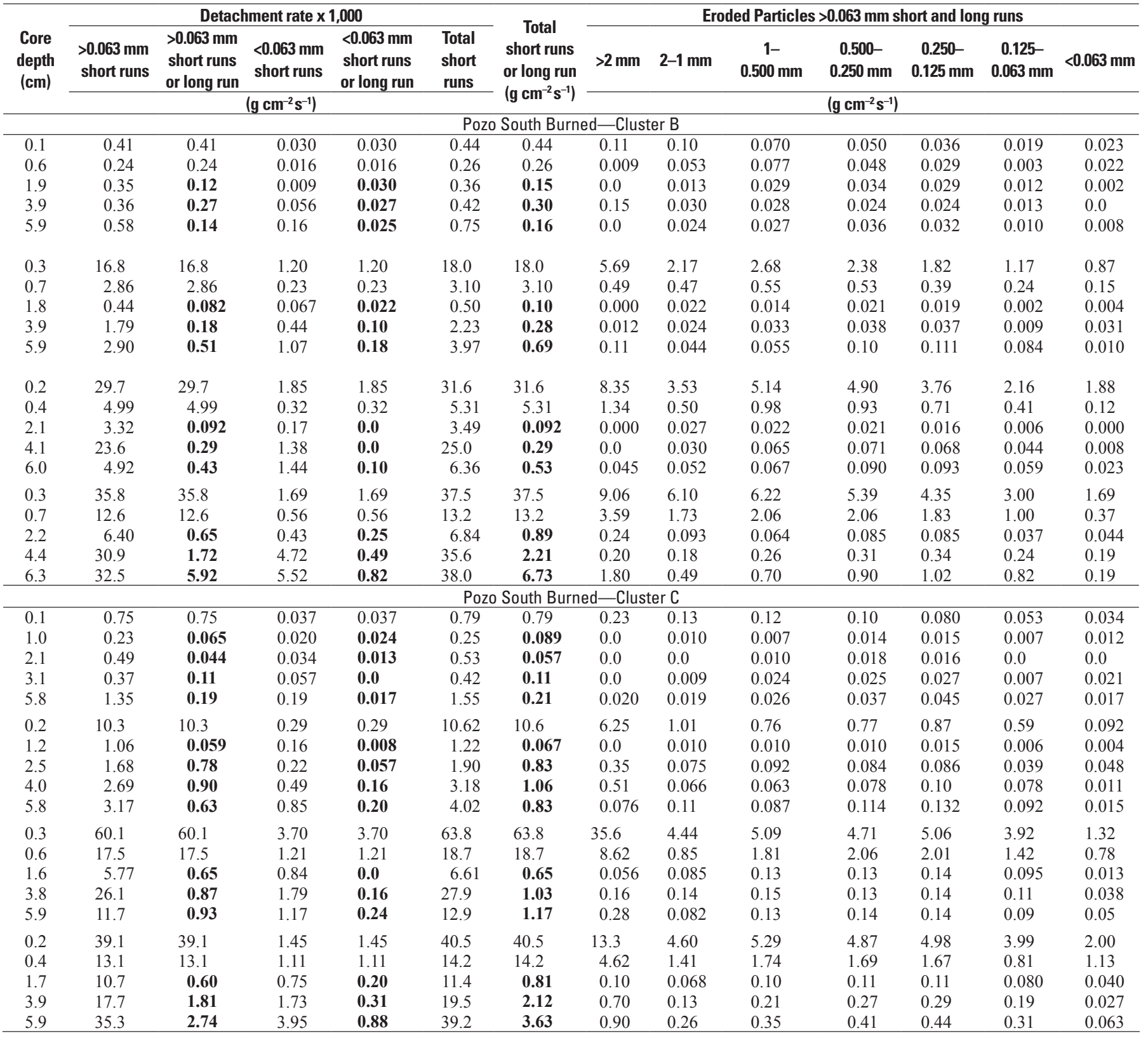




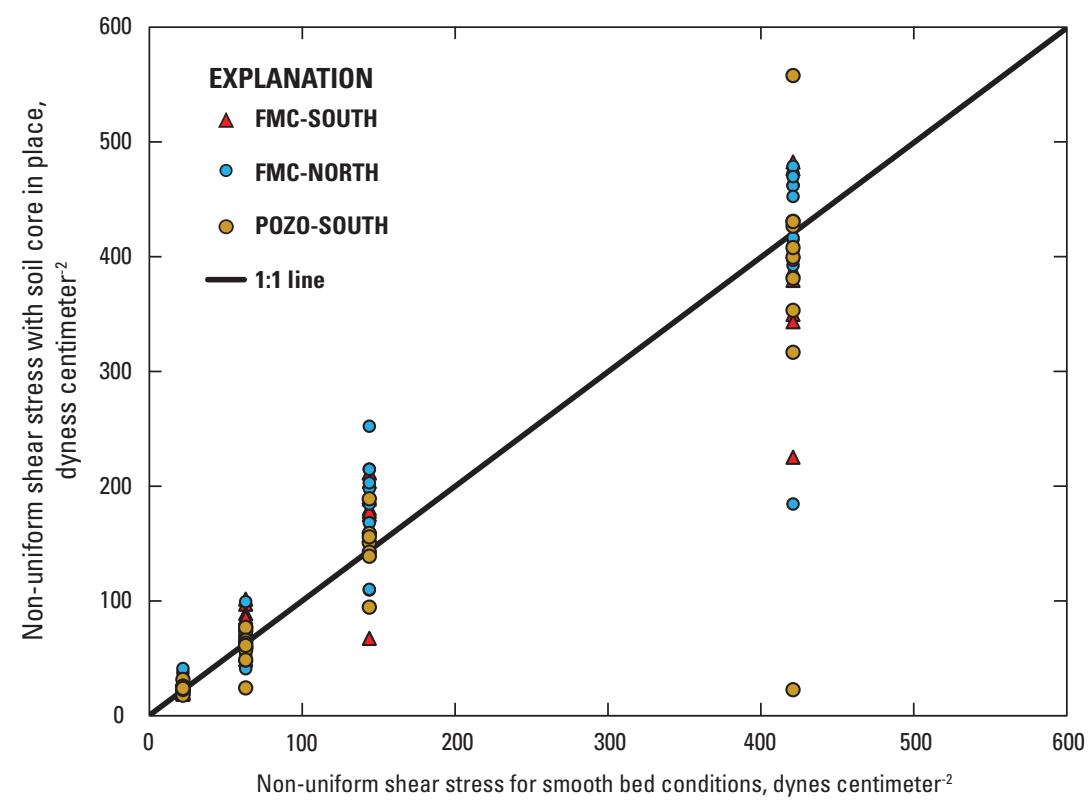

Figure 6. Comparison of non-uniform shear stress measured for the tilting flume with a smooth bed conditions and with a soil core in place.

following correlation equations were then used to estimate the detachment rate for the long runs for the initial experiments (values in bold italics in tables 4-6). For $>0.063-\mathrm{mm}$ size fraction, the equations are:

Fourmile Canyon South: $L=0.357(L S)^{1.04}, \mathrm{R}^{2}=0.92$

Fourmile Canyon North: $L=0.405(L S)^{1.04}, \mathrm{R}^{2}=0.95$

Pozo South: $L=0.407(L S)^{1.01}, \mathrm{R}^{2}=0.89$

where

$L \quad$ is the long run detachment rate in $\mathrm{g} \mathrm{cm}^{-2} \mathrm{~s}^{-1}$, and $L S \quad$ is the combined long and short run detachment rate in $\mathrm{g} \mathrm{cm}^{-2} \mathrm{~s}^{-1}$.

For $<0.063$-mm size fraction, the equations are:

Fourmile Canyon South: $L=0.630(L S), \mathrm{R}^{2}=0.73$

Fourmile Canyon North: $L=0.215(L S), \mathrm{R}^{2}=0.75$

Pozo South: $L=0.331(L S), \mathrm{R}^{2}=0.82$

\section{Results and Discussion}

Two types of data were collected from three different sites and are presented in this report. The first type of data describes the soil and root properties, and the second type is associated with the flume experiments to measure soil detachment. Results are presented in the order FMC-South, FMCNorth, and Pozo-South unless otherwise noted. Mean values of all properties represent the average of three replicates for each of three clusters from the burned areas or nine samples, and the average of three samples (one cluster) from the unburned area.

\section{Soil Properties}

Bulk density generally increased with depth below the surface of the soil. Bulk density for each unburned area was affected by the amount of organic matter in the surface samples. The FMC-South site had the largest amount of organic material and thus the lowest bulk density (dashed blue line in fig. 7) at the surface. This effect decreased with depth such that the mean bulk densities at $6.3 \mathrm{~cm}$ were $1.28,1.49$, and $1.41 \mathrm{~g} \mathrm{~cm}^{-3}$ for the soils from FMC-South, FMC-North, and Pozo-South. Mean values for soils from the burned area at the surface $(0.5 \mathrm{~cm})$ were essentially the same $(1.04$ and $1.07 \mathrm{~g} \mathrm{~cm}^{-3}$ ) for the FMC-South and FMC-North sites, but the mean value at the Pozo-South site was greater $\left(1.25 \mathrm{~g} \mathrm{~cm}^{-3}\right)$ than the two FMC sites (tables 1-3). Corresponding mean values at $6.3 \mathrm{~cm}$ were $1.38,1.28$, and $1.31 \mathrm{~g} \mathrm{~cm}^{-3}$. Values at the deepest depth $(8.8 \mathrm{~cm})$ were more variable; due to their location at the end of the core, it was difficult to always obtain a sample exactly $2.5 \mathrm{~cm}$ thick. Thus, the volume used in the bulk density calculation had more uncertainty than at shallower depths. 


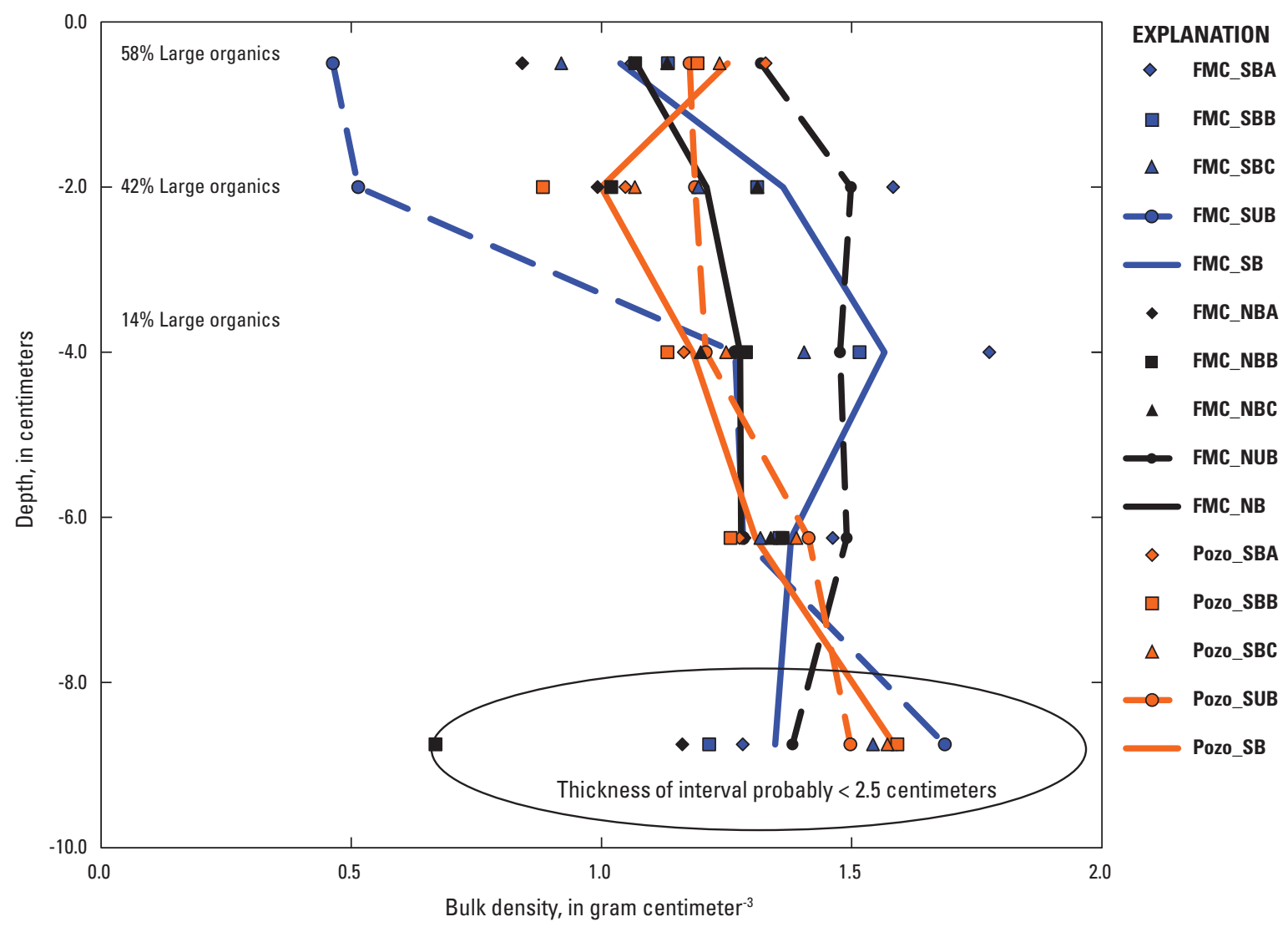

Figure 7. Mean bulk density of soil for three sites based on three replicates for each cluster. Each cluster (A, B, and $C$ at the end of the three-letter code following the site name) from a burned (B) area is plotted separately, and the mean values of the three clusters are connected by a solid line. The mean values for the single cluster (three replicates) from the unburned (UB) area are connected by a dashed line. (FMC, Fourmile Canyon site; S, south aspect; $\mathrm{N}$, north aspect)

Organic matter in the soil, as measured by loss on ignition, generally decreased with depth below the surface of the soil. Samples from the FMC-South site had the most organic matter incorporated into in the surface soil (43.8 percent), those from the FMC-North site had the least organic matter (4.9 percent), and those from the Pozo site had 6.0 percent. Burning this organic matter generally reduced the mean values for soils in the burned area so that at the surface $(0.5 \mathrm{~cm})$ they were 7.2 percent, 6.1 percent, and 4.2 percent. The exception is the mean value for the FMC-North site, which had some residual unburned duff material that the other sites did not have. The three clusters collected in the FMC-North site also had more variability than the other sites with values ranging from 3.2 percent (less than the unburned value) to 9.8 percent (table 2). Mean values of organic matter at the deepest depth $(8.8 \mathrm{~cm})$ in the burn areas were essentially minimum values at all sites and were 3.1 percent, 4.0 percent, and 3.4 percent, respectively (fig. 8).

Percent of silt and clay $(<0.063 \mathrm{~mm})$ differed more between the three sites than did the bulk density or the amount of organic matter. Silt and clay percentages of the surface soils $(0.5 \mathrm{~cm})$ from the unburned area in the FMC-South $(5.8$ percent ) and FMC-North (9.3 percent) sites were less than at the Pozo site (10.6 percent), which had a thin veneer of fine gravel on the surface; this created a minimum value of silt and clay at the surface (tables 1, 2, and 3). Below the surface, the percent of silt and clay decreased with depth (fig. 9). A rain storm caused some runoff after the Pozo fire and before we collected samples in January, 2011. This runoff removed some of the veneer of fine gravel and the percent silt and clay at the surface was greater in the burned area than in the unburned area. Samples from the burned area in the Pozo site had the largest percentage at all depths with the mean values decreasing from 23.4 percent $(0.5 \mathrm{~cm})$ to 19.4 percent $(8.8 \mathrm{~cm})$. Similar percentages for the burned area in the FMC-North site were substantially less (ranging from 14.4 percent to 7.3 percent), and the lowest percentages were in the FMC-South (ranging from 8.0 percent to 5.1 percent) (fig. 9).

\section{Root Properties}

The root density $R D$ and root-length density $R L D$ varied between sites. The $R D$ and $R L D$ measurements near the soil surface $(0-1 \mathrm{~cm})$ in unburned clusters at Fourmile Canyon 


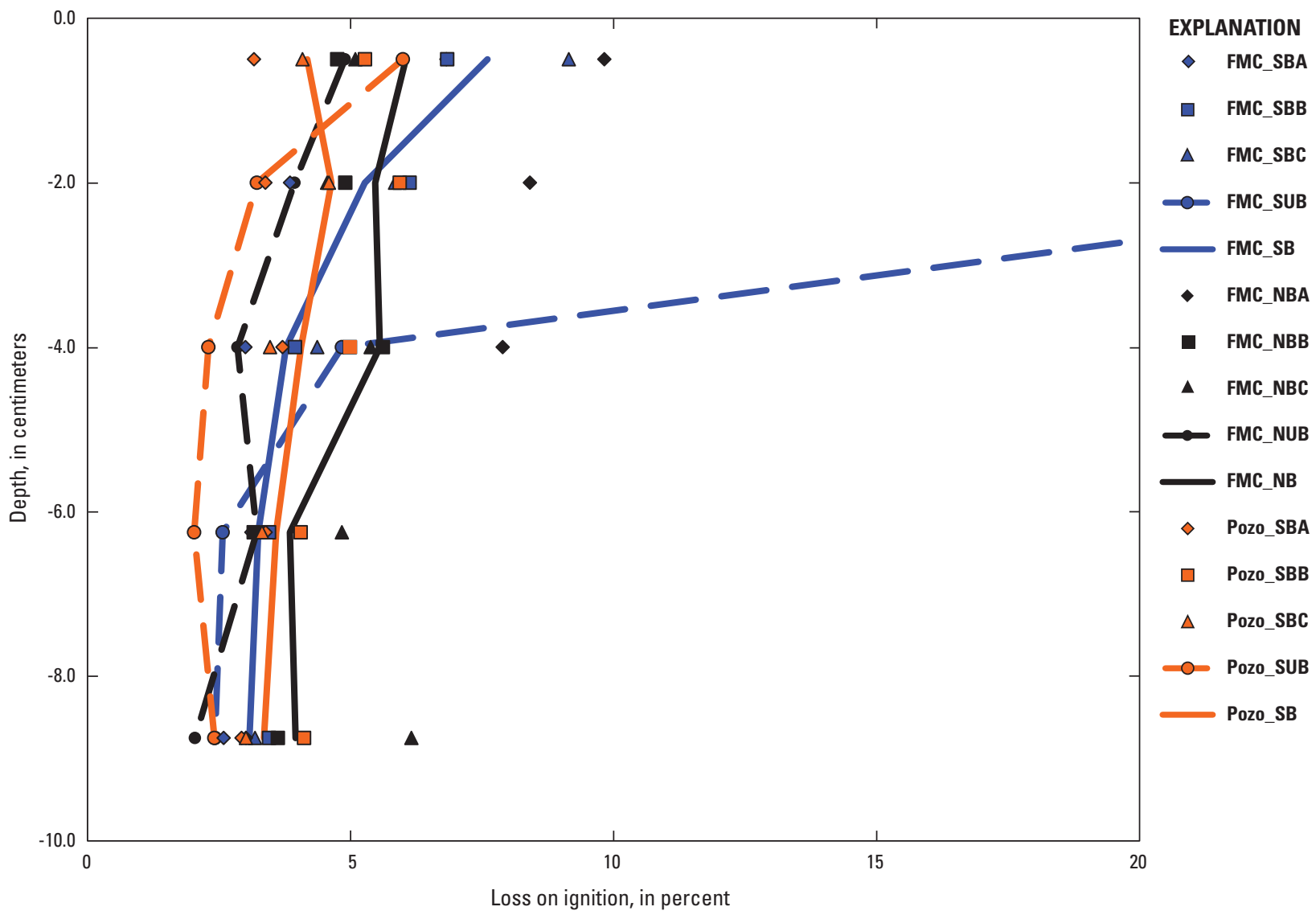

Figure 8. Loss on ignition (LOI) of soil for three sites based on three replicates for each cluster. Each cluster (A, B, and $C$ at the end of the three-letter code following the site name) from a burned (B) area is plotted separately, and the mean values of the three clusters are connected by a solid line. The mean values for the single cluster (three replicates) from the unburned (UB) area are connected by a dashed line. The value for FMC-south in the unburned area at the surface $(-0.5 \mathrm{~cm})$ not shown on the figure is 43.8 percent. (FMC, Fourmile Canyon site; $\mathrm{S}$, south aspect; $\mathrm{N}$, north aspect)

were consistently higher than the burned clusters. At Pozo, there was no difference between the burned and unburned clusters. At FMC-South and FMC-North, the $R D$ and $R L D$ had maximum values between 2 and $5 \mathrm{~cm}$ below the surface, whereas at the Pozo site these root properties increased monotonically with depth (fig. 10). $R D$ and $R L D$ were generally lower in the soils from the Pozo site than from the Fourmile Canyon site (figs. 10 and 11). $R D$ and $R L D$ were more variable near the surface above $4 \mathrm{~cm}$ and less variable below $4 \mathrm{~cm}$. Overall, $R D$ was more variable at FMC-North, and less variable at Pozo than $R L D$. At FMC-South, the overall variability in the two root properties were similar.

$R D$ and $R L D$ are related. However, the relation between the two root properties is weak (fig. 12), as expected given that root density is highly influenced by short and thick roots, whereas $R L D$ is strongly influenced by fine roots which have low mass but may be very long (for example, mycorrhizas). A steeper slope in (fig. 12) indicates more root length per unit mass of root. Abundant mycorrhizas were found in some samples from Fourmile Canyon usually at depths above 3 $\mathrm{cm}$. Mycorrhizal associations are commonly reported in roots systems of Douglas Fir stands in both near surface organics and in mineral soil (Kluber and others, 2010).

\section{Soil Detachment Rates}

The detached soil was separated into two fractions $(>0.063 \mathrm{~mm}$ and $<0.063 \mathrm{~mm}$ ) during each experimental run. The $>0.063 \mathrm{~mm}$ eroded sediment was further separated into seven size classes (tables 4-6) after drying (see "Laboratory Methods" section above). One of the size classes was $<0.063$ $\mathrm{mm}$, but this class represents those aggregates that broke during the sieve analysis. The five cores composing a cluster were collected within a $1-\mathrm{m}$ radius, so that we assumed they were similar and a different core could be used for each shear stress. However, the clusters themselves were separated by distances on the order of 50-500 m, so that there may be substantial differences in soil properties; therefore, data were analyzed for each separate cluster. This separation was warranted for other reasons. For example, the FMC-North Cluster A was unique because these cores were collected from under a tarp, which had been put in place about 2 weeks (mid-September, 


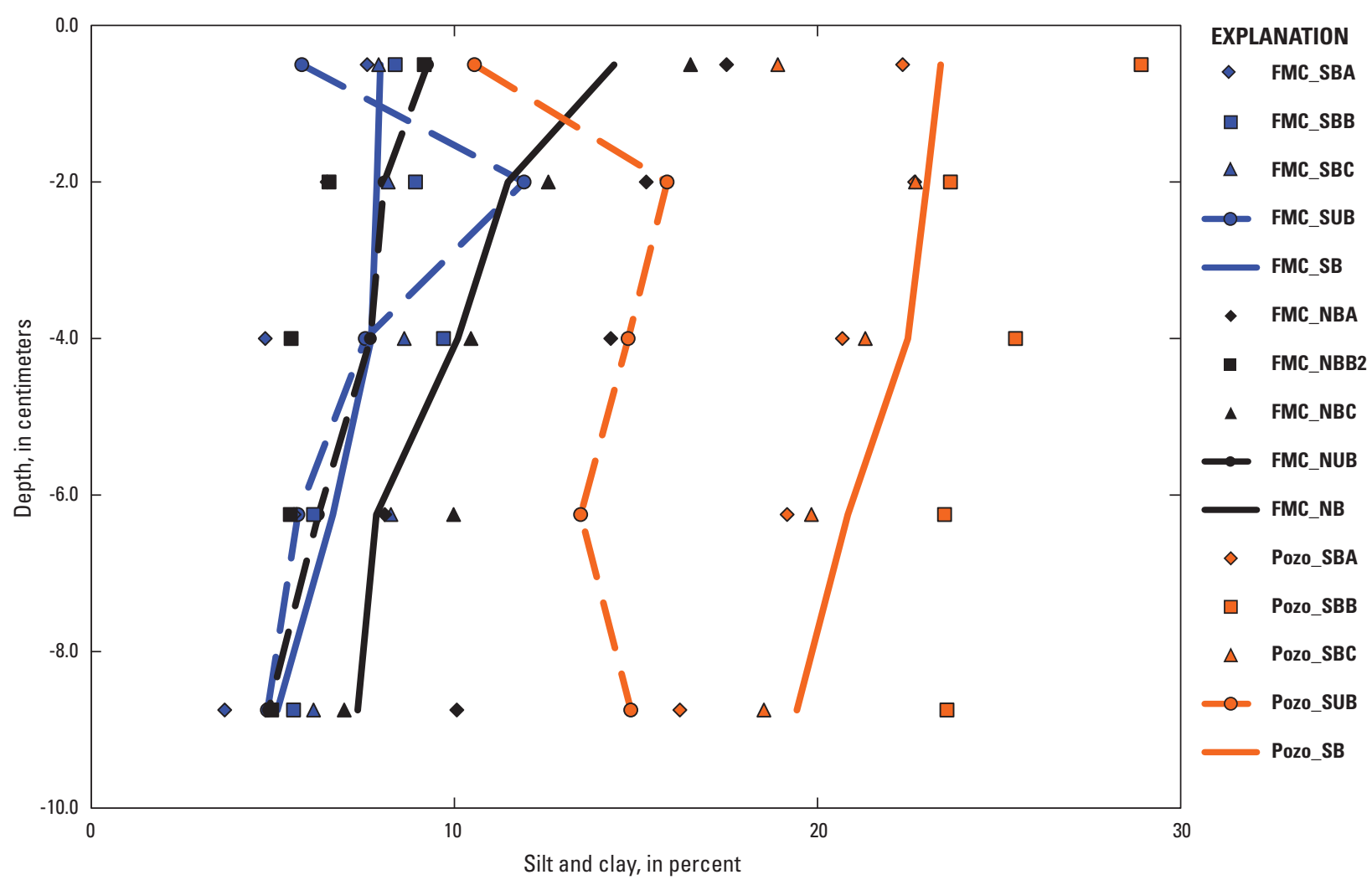

Figure 9. Percent silt and clay (less than $0.063 \mathrm{~mm}$ ) in soil for three sites based on three replicates for each cluster. Each cluster ( $A, B$, and $C$ at the end of the three-letter code following the site name) from a burned (B) area is plotted separately, and the mean values of the three clusters are connected by a solid line. The mean values for the single cluster (three replicates) from the unburned (UB) area are connected by a dashed line. (FMC, Fourmile Canyon site; S, south aspect; N, north aspect)

2010) after the 2010 Fourmile Canyon fire was contained in order to preserve the ash layer on the surface. The FMC-North Cluster B cores were also unique in that they were collected 1 year (yr) after the wildfire (in October, 2011), and during the intervening time, wind and water erosion had altered the surface. Additionally, there was only a single cluster from each unburned site.

\section{Non-Uniform Shear Stress and Root-Length Density}

Detachment rates and transport rates have often been related to the variables of boundary shear stress or stream power. Both variables are frequently expressed as the excess shear stress or excess stream power that is greater than some critical shear stress or critical stream power. The range of critical shear stress values for particle diameters from $0.063 \mathrm{~mm}$ to $1.0 \mathrm{~mm}$ is 2-8 dynes $\mathrm{cm}^{-2}$ (Wiberg and Smith, 1987; Moody and others, 2005), and these are much smaller than the shear stress $\left(22-421\right.$ dynes $\left.\mathrm{cm}^{-2}\right)$ used in these experiments. It is unlikely that we could determine the critical shear stress or critical unit stream power values. Thus, as a first step, we determined the relations between the detachment rate and the non-uniform shear stress for the $>0.063 \mathrm{~mm}$ and $<0.063-\mathrm{mm}$ size fractions of the eroded sediment. For non-cohesive sediment in streams, the literature (Meyer-Peter and Müller, 1948; Roberts and others, 1998; Yang, 2006) indicates that the relation between detachment rate or transport rate and shear stress is generally a power law with exponent $>1$ and often equal to 1.5 .

Some literature for soils and cohesive sediments (Foster, 1982; Lane and others, 1987; Elliot and others, 1989; Foster and others, 1995; Nachtergaele and Poesen, 2002; Huang and others, 2006) indicates that the exponent of the power law may be $<1$. So, as an initial investigation, a power law was fit to the data for non-uniform shear stress, $\tau_{N}$, and non-uniform unit stream power, $\omega_{a N}$. Deviations from the power-law form of the relation may indicate some type of cohesive or root effects. For some samples of the $<0.063 \mathrm{~mm}$ fraction, there was a trace amount of sediment, and these values are listed in tables 4, 5, and 6 as "0.0." Zero cannot be used when fitting a power law, so that for depths with " 0.0 " a linear relation passing through $(0,0)$ was computed (see "Laboratory Method" section above and tables 4,5 , and 6 ). 


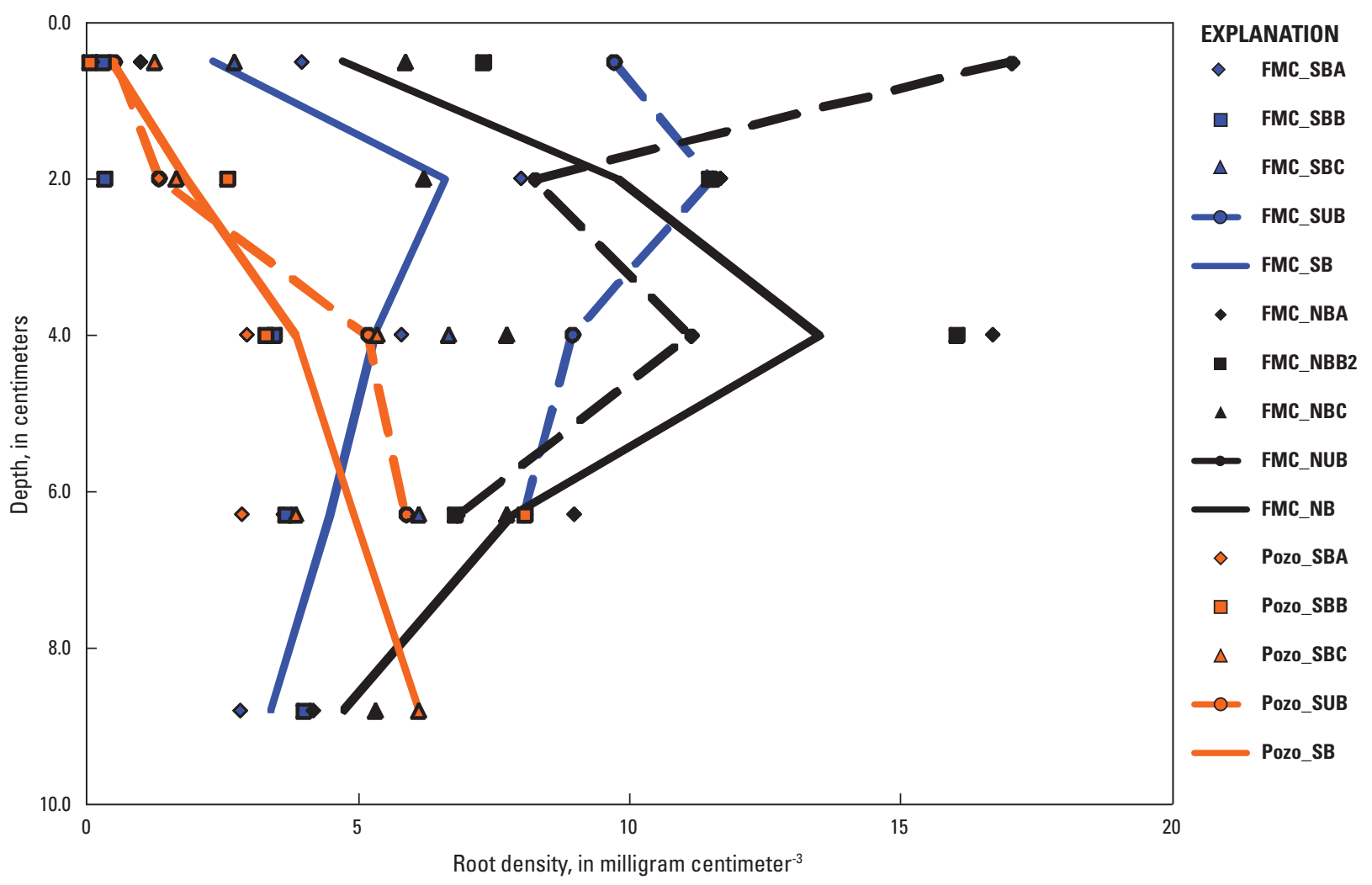

Figure 10. Root density as a function of depth in the soil for three sites based on three replicates for each cluster. Each cluster ( $A, B$, and $C$ at the end of the three-letter code following the site name) from a burned (B) area is plotted separately, and the mean values of the three clusters are connected by a solid line. The mean values for the single cluster (three replicates) from the unburned (UB) area are connected by a dashed line. (FMC, Fourmile Canyon site; S, south aspect; $\mathrm{N}$, north aspect)

Detachment rates could also depend on root and cohesive properties of the soils. Therefore, as a second step, we determined the power-law relation between detachment rates and root-length density for the $>0.063-\mathrm{mm}$ and $<0.063-\mathrm{mm}$ size fractions. Values of $R L D$ were not extracted for each core measured in the flume, but were the average for specific depth intervals $(0-1,1-3,3-5,5-7.5$, and $7.5-10 \mathrm{~cm})$ from the three replicate cores collected from the same site. These values were interpolated to determine values of $R L D$ at the specific depths of the detachment measurements, and were extrapolated to the surface by using two different assumptions. The first assumption was that $R L D$ at the soil surface was zero and $R L D$ values were interpolated values between 0 and $0.5 \mathrm{~cm}$, and the second assumption was that $R L D$ was a constant between the soil surface and $0.5 \mathrm{~cm}$, and the value was constant and equal to the value of $R L D$ at $0.5 \mathrm{~cm}$. Power laws for $\tau_{N}$ and $\omega_{a N}$ were fit to four values of shear stress or stream power (applied to four different cores) for five depth ranges (depths were not exactly the same for each core), whereas the power laws for $R L D$ were fit to four values of $R L D$ within the same core having the same non-uniform shear stress or stream power.

The coefficient of determination, $\mathrm{R}^{2}$, was used to indicate the goodness-of-fit to the power law relations between the detachment rate and the $\tau_{N}$ or the root-length density. Five value of $\mathrm{R}^{2}$ (one for each depth) for the power law fits using $\tau_{N}$ or $\boldsymbol{w}_{a N}$ for each cluster were averaged. Similarly, the four values of $\mathrm{R}^{2}$ (one for each value of $\tau_{N}$ ) for the power law fits using $R L D$ were averaged for each cluster. How the $R L D$ was extrapolated to the surface made little difference, so $\mathrm{R}^{2}$ values are given here for the first assumption $(R L D=0$ at the soil surface). For the $>0.063 \mathrm{~mm}$ fraction, the $\mathrm{R}^{2}$ values for all clusters ranged from 0.33 to 0.86 for $\tau_{N}$ and from 0.07 to 0.91 for $R L D$ (fig. 13A) indicating a wide range of spatial variability. Spatial variability between sites is certainly expected, but the spatial variability between clusters within each site was surprising. For example, two very different clusters (Cluster B from FMC-North collected $1 \mathrm{yr}$ after the wildfire and the Pozo unburned) had the highest $\mathrm{R}^{2}$-values for $\tau_{N}$ and the lowest for $R L D$ (fig. 13A).

However, the FMC-North cluster A collected under the tarp with the ash layer intact had the combined lowest $\mathrm{R}^{2}$-values for $\tau_{N}(0.33)$ and $R L D(0.56)$. The highest $\mathrm{R}^{2}$-values for $R L D$ were again from two different sites: the FMC-South Cluster C (0.91) with relatively constant exponents (-1.1 to -2.7) and Pozo Cluster A (0.85) with approximately constant exponents $(-2.1$ to -2.8$)$. The exponent of the power law for 


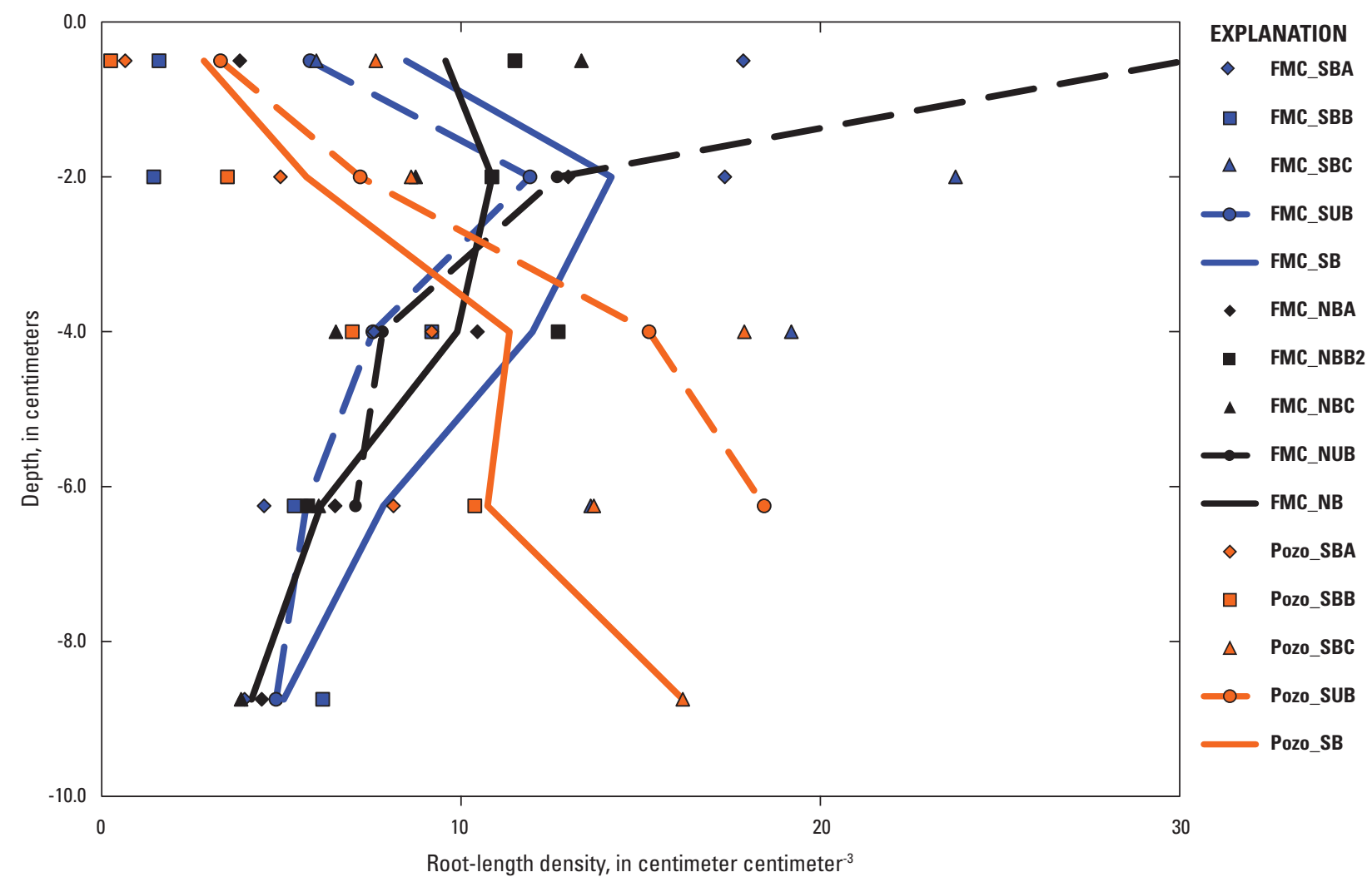

Figure 11. Root-length density as a function of depth in the soil for three sites based on one replicate for each cluster. Each cluster ( $A, B$, and $C$ at the end of the three-letter code following the site name) from a burned (B) area is plotted separately and the mean values of the three clusters are connected by a solid line. The mean values for the single cluster (three replicates) from the unburned (UB) area are connected by a dashed line. (FMC, Fourmile Canyon site; S, south aspect; $\mathrm{N}$, north aspect).

$R L D$ varied from -9.5 to 5.3 and the exponent of the power law for $\tau_{N}$ ranged from -0.34 to 2.5 . No clusters showed any consistent pattern with depth. This wide variability of goodness-of-fit and the value of the exponent for the power laws indicated that a multiple regression including both variables was justified.

For the $<0.063 \mathrm{~mm}$ size fraction, only two clusters had $\mathrm{R}^{2}$ values for $R L D>0.60$. These were the FMC-South Cluster $\mathrm{C}\left(\mathrm{R}^{2}=0.65\right)$, which was noted in the field to have many cacti roots and has a distinct maximum at $2 \mathrm{~cm}$ depth for the $R L D$ (fig. 8), and Pozo Cluster $\mathrm{A}\left(\mathrm{R}^{2}=0.63\right)$, which also had a high $\mathrm{R}^{2}$-value (0.85) for the $>0.063 \mathrm{~mm}$ size fraction. Only 4 of the 12 clusters had $\mathrm{R}^{2}$ values for $\tau_{N}$ greater than 0.60 compared to seven clusters for the $>0.063 \mathrm{~mm}$ size fraction (fig. 13B). These results suggest that the detachment rate for the $<0.063$ $\mathrm{mm}$ size fraction is generally not dependent on $\tau_{N}$ or $R L D$. Based on the low $\mathrm{R}^{2}$-values for $<0.063 \mathrm{~mm}$ size, no multipleregression analysis was done for the $<0.063 \mathrm{~mm}$ size fraction.

\section{Non-Uniform Unit Stream Power and Root-length Density}

The results based on the non-uniform unit stream power were almost the same as those based on the non-uniform shear stress. On average the $\mathrm{R}^{2}$-values were slightly greater $(0.03)$, but were not statistically significant ( $\mathrm{p}=0.085$; paired $\mathrm{t}$-test). The slight improvement is probably because $\omega_{a N}$ was calculated by using the measured discharge, which varied slightly for the five experimental runs for a given core, whereas $\tau_{N}$ was constant for the five runs. The measured $\tau_{N}$ also may provide improved goodness-of-fits. Unfortunately, there are only 20 runs out of the total of 60 runs for all sites that had measured $\tau_{N}$ values for all four shear stresses, and 45 percent of these did indicate slight improvements in the goodness-of-fit similar to the data for $\omega_{a N}$. 

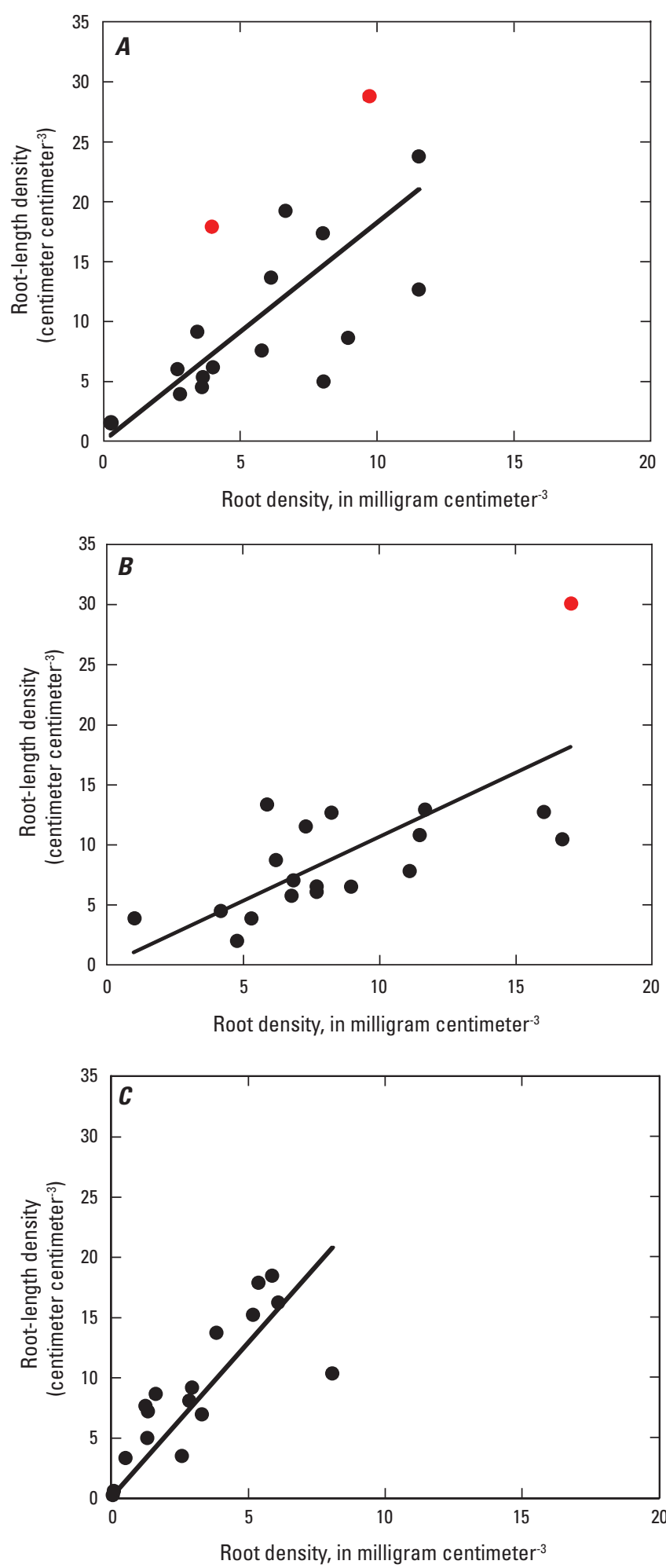

Figure 12. Relations between root-length density and root density. $A$, Fourmile Canyon-North; $B$, Fourmile Canyon-South; $C$, Pozo. Red points indicate samples where mycorrhizas were present and included as part of root-length density estimates.

\section{Multiple Regressions using Flow and Root Variables}

Multiple regression analysis was done for just the $>0.063 \mathrm{~mm}$ size fraction using the root-length density and the non-uniform shear stress or the non-uniform stream power as independent variables. The general form of the relation for the detachment rate, $E\left[\mathrm{~g} \mathrm{~cm}^{-2} \mathrm{~s}^{-1}\right]$ is:

$$
E=b 1 t_{N}^{b 2} R L D^{b 3},
$$

where

$$
\begin{aligned}
& b 1 \text { is a constant and } \\
& b 2 \text { and } \\
& b 3 \text { are exponents determined by the multiple } \\
& \text { regression analysis (table } 7 .)
\end{aligned}
$$

The first assumption relative to extrapolating $R L D$ to the surface $\left(R L D=0 \mathrm{~cm} \mathrm{~cm}^{-3}\right.$ at $\left.0 \mathrm{~cm}\right)$ was used, and all data were $\log$ transformed. Regression models (Brown, 2009) for each cluster were run separately (table 7), and all the data were combined rather than separating by depth (as done for the initial regression for $\tau_{N}$ and $\omega_{a N}$ ) or by shear stress (as done for the initial regression for root-length density). Because the data were log transformed, another measure of goodness-of-fit, the log RMSE (table 7), was used for these multiple regression models. This measure is the square root of the mean of the square values of the natural logarithm of the ratio of the predicted value divided by the measured value (Kroll and Stedinger, 1996). The goodness-of-fit as indicated by the $\mathrm{R}^{2}$-value was higher (minimum $\mathrm{R}^{2}=0.11$ ) for these multiple regression models than for the single variable regression models (minimum $\mathrm{R}^{2}=0.0014$ ) discussed in the previous section. However, there was still a wide range of values for the exponents ( $b 2$ and $b 3$, table 7) for the independent variables.

Exponents for the $R L D$ were mostly negative (fig. 14; except for FMC-SA and FMC-NC); this indicates that the detachment rate decreased with an increase in $R L D$. Exponents for the $\tau_{N}$ (or $\omega_{a N}$ ) were always positive (fig. 14) and had a narrower range of values equal to 0.34 to 1.96 ( 0.11 to 1.29 ) compared to those for the initial single regression models, which were -0.34 to 2.5 ( -0.73 to 2.1$)$. Exponents for $\tau_{N}$ were always greater than those for $\omega_{a N}$ and averaged 1.01 and 0.83 , respectively, based on all data from burned and unburned areas. This is probably due to the fact that the stream power is the shear stress multiplied by the mean velocity (related to energy or power). Overall the multiple regression models predicted the detachment rates for the Pozo soils best with $\mathrm{R}^{2}$-values ranging from 0.60-0.79 using $\tau_{N}$ and from 0.63 to 0.84 using $\omega_{a N}$. Average values (for all clusters from all burned areas) were $b 1$ $=-1.80, b 2=0.82$ and $b 3=-0.88$. Similar results were found using the non-uniform stream power $(b 1=-3.62, b 2=0.67$, and 

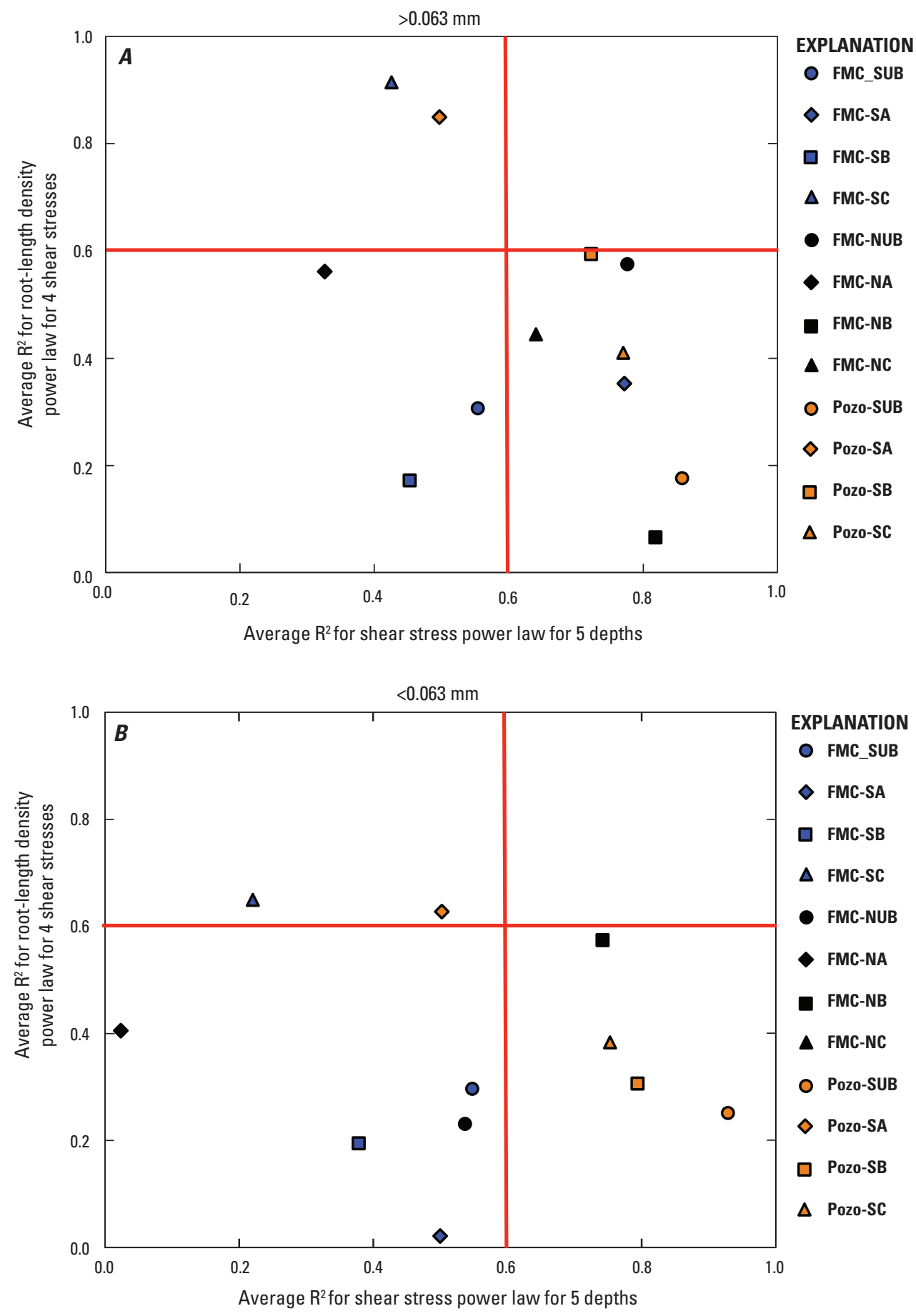

Figure 13. Comparison of the goodness-of-fit as measured by the coefficient of determination for power law relations between the detachment rate and the non-uniform shear stress or the root-length density. $A$, greater than $0.063 \mathrm{~mm}$ size fraction. $B$, less than $0.063 \mathrm{~mm}$ size fraction. The red lines are drawn at an arbitrary value of $R^{2}=0.60$ (coefficient of determination) to separate those correlations that may be physically realistic from those that are probably not. 
Table 7. Multiple regression information for the detachment rate as a function of root-length density and either non-uniform shear stress or non-uniform stream power.

[FMC, Fourmile Canyon; UB, unburned; S, South; N, North; b1 is a constant, b2 and b3 are exponents in the equation $E=b 1 \tau_{\mathrm{N}}{ }^{\mathrm{b} 2} \mathrm{RLD}^{\mathrm{b} 3}$ where $\tau_{\mathrm{N}}$ is the non-uniform shear stress and RLD is the root-length density; $\mathrm{R}^{2}$, coefficient of determination; log RMSE, error statistic equal to the root mean square of the logrithm of the predicted value divided by the observed value]

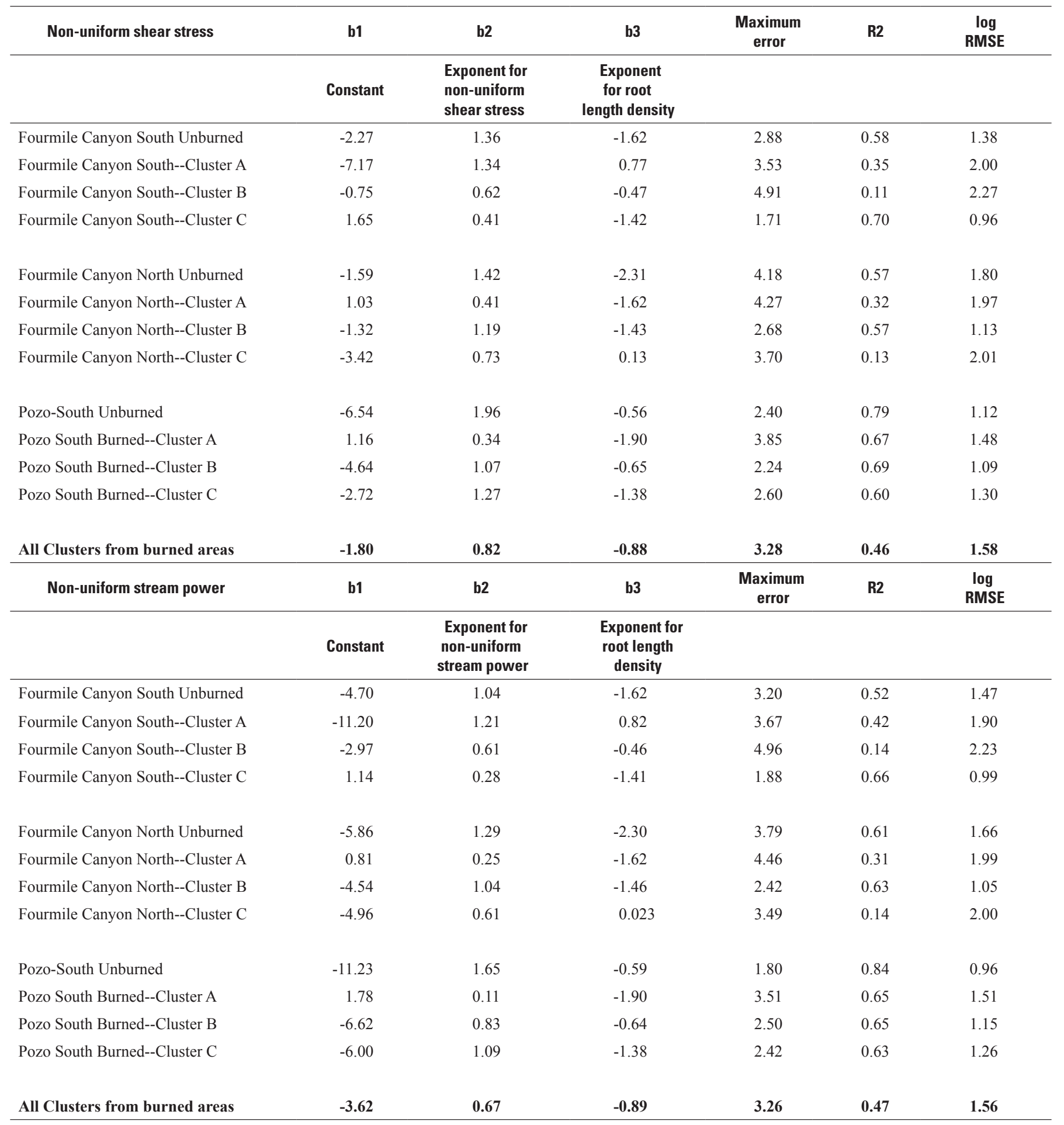



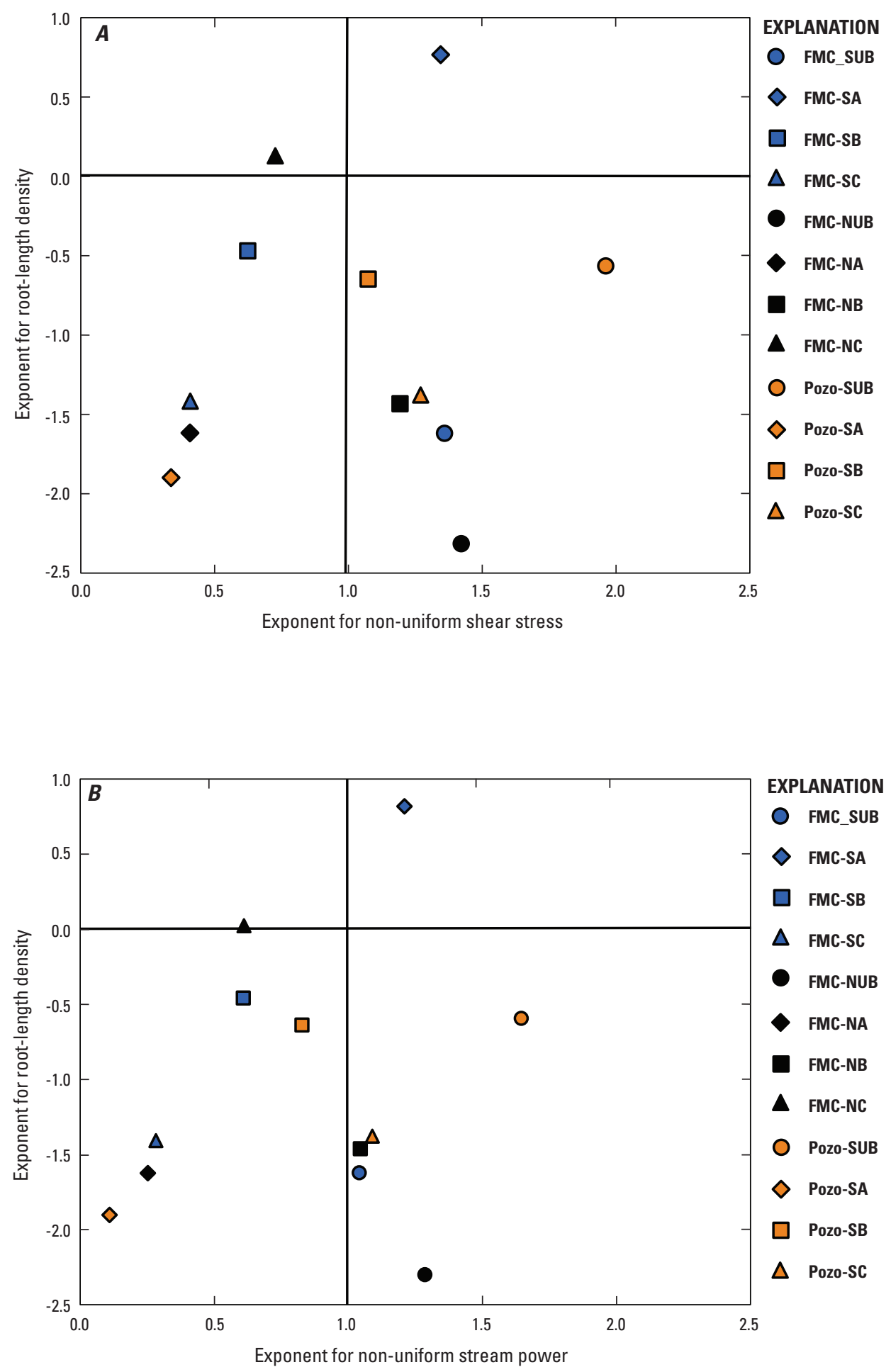

Figure 14. Exponents of the independent variables used in multiple regressions of log transformed data in which detachment rate for greater than $0.063 \mathrm{~mm}$ size fraction is the dependent variable. $A$, Root-length density and non-uniform shear stress. $B$, Root-length density and non-uniform stream power. 
$b 3=-0.88$; table 7). These results indicate that the erodibility parameters for soil within burned areas need to include depth and root properties.

The wide variation in multiple regression models for the detachment rate from the multiple clusters and sites suggest that there is not a single model. A single model for nonuniform shear stress and a single model for non-uniform unit stream power were tested by using all the data from just the nine clusters collected from the burned sites (176 values) to determine two models. The goodness-of-fit for these models is low $\left(\mathrm{R}^{2} \sim 0.25\right.$; log RMSE $\left.\sim 1.94\right)$, over predicts detachment ranges at the low end, and under predicts detachment rates at the high end of the measured detachment rates (fig. 15).

\section{Soil Erodibility}

If the detachment rate, $E$, is a linear relation of some flow variable, $X$, then the erodibility can be simply defined as $K=E / X$, which makes the implicit assumption that the erodibility is a constant property of a given soil. Results from this study measured a wide range of exponents for the flow variables $\tau_{N}$ and $\boldsymbol{w}_{a N}$ for each cluster. These exponents were not equal to 1 (table 7), which suggests some form of non-linear relation is appropriate. However, the range was even wider for the single variable regressions but decreased considerably when the root-length density parameter was included in the multiple regressions. This implies that $K$ is not a constant property of the soil but also a function of root properties. If $n$ in the relation $E=K X^{n}$ is not equal to 1, then the meaning of

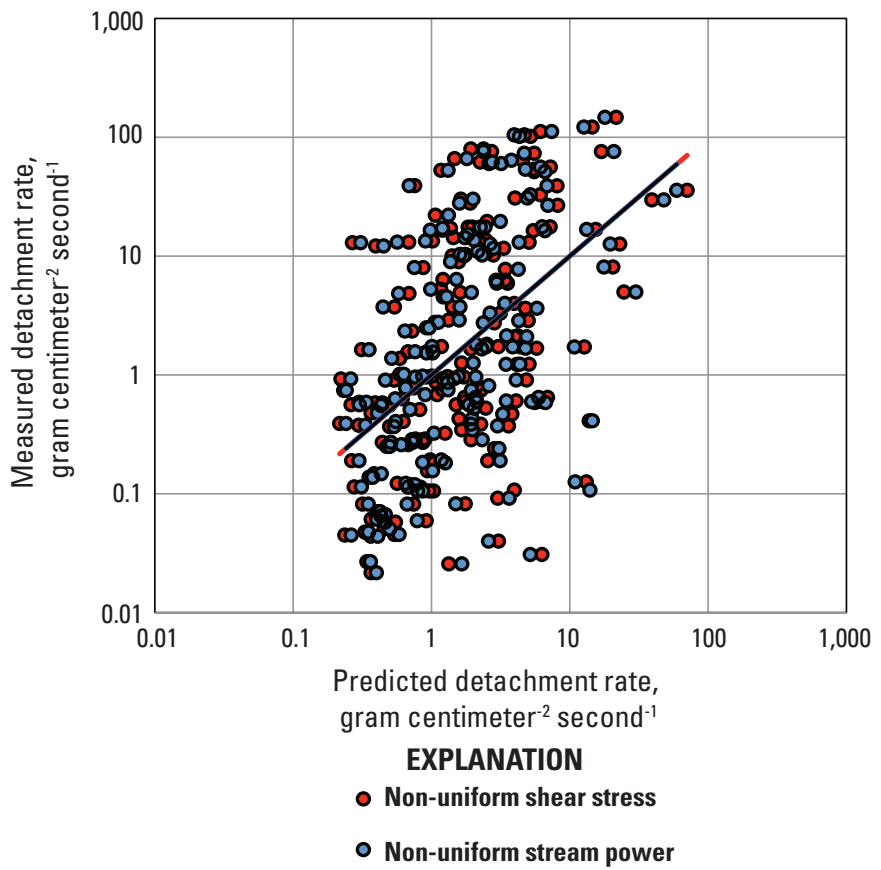

Figure 15. Multiple regression model for detachment rates using all shear stress, stream power, and root-length density data for clusters collected in burned areas. $R^{2}$-value (coefficient of determination) is roughly 0.25 .
$K$ becomes hard to define. Interestingly, the average values of all 12 exponents (table 7) determined for $\tau_{N}$ was $1.00 \pm 0.50$ ( \pm standard deviation), and for $\omega_{a N}$ the average was $0.85 \pm$ 0.47 , which suggests $\tau_{N}$ might be the appropriate flow variable to use when computing erodibility (fig. 16). However, this changes when the exponents for the unburned and burned data are separated. The average value for the unburned sites are $\tau_{N}$ $=1.58 \pm 0.33$ (similar to the exponent used for some sediment transport laws; Meyer-Peter and Müller, 1948; Roberts and others, 1998; Yang, 2006) and $\omega_{a N}=1.33 \pm 0.31$, whereas for the burned sites the averages are $0.82 \pm 0.40$ and $0.67 \pm 0.40$, respectively making the decision on how to define $K$ more uncertain.

Including the $R L D$ variable as an explicit part of $K$ made the exponents of the flow variable less diverse and closer to 1. It is possible that by including other types of soil variables (physical, chemical, biological, and burn severity; Busse and DeBano, 2005; DeBano and others, 2005; Knoepp and DeBano, 2005), such as soil moisture (Bryan, 2000; Nachtergaele and Poesen, 2002) or a particle-size parameter, would help to decrease the variability more and the erodibility would become a linear function of one of the flow variables. However, this is beyond the immediate objective of this report. Soil moisture changes with time and other properties may also change (Bryan, 2000). This is highlighted by the results for the FMC-NB cluster, which was collected $1 \mathrm{yr}$ after the wildfire in 2011. During this time, the Fourmile Canyon burned area was affected by snow cover during the winter and by spring melt and later by cyclonic and convective rainstorms during the spring, summer, and fall; all types of precipitation likely eroded some of the surface material. Soil erodibility results for this cluster were quite different than those for the FMC-NC cluster (collected soon after the wildfire in 2010); this suggests changes in $K$ with time.

Better measurements of the actual shear stress and stream power values experienced by the soil particles at the surface of the core would most likely improve the detachment relations. This would require being able to subtract out from the total boundary shear stress, for example, the shear stress associated with the drag on the protruding roots tips or stems (fig. 17A) and small particles on the order of $0.2-1.0 \mathrm{~mm}$ (fig. 17B). Both represent a substantial drag (Smith, 2004) for shallow flows on the order of 3-11 mm deep, which were used in these experiments and are certainly typical of overland flows on burned hillslopes. As the surface evolved during the flow, numerous pits developed that affect the flow and hence the shear stress and stream power available to erode sediment. Additionally, we observed air films that developed (usually on highly repellent surfaces) between the surface of the core and the water (fig. 17C). These air films have been observed by others (Moody and others, 2005) in flume studies and prevented any erosion of the surface until air escaped in bursts from beneath the soil surface; this movement detached soil particles and aggregates. The exact areal distribution of air film during overland flow in the field has not been determined, but might be considered in future research. 

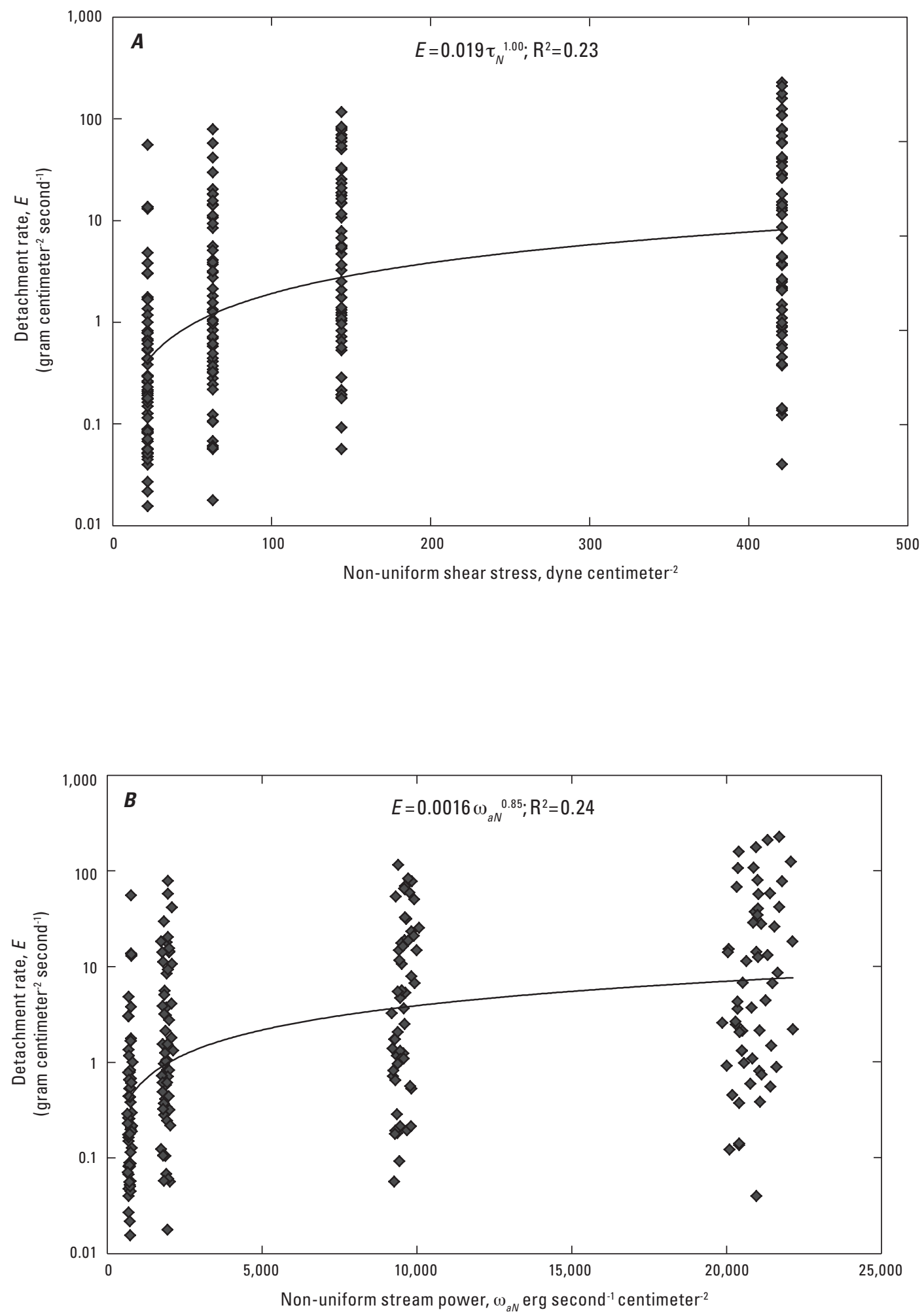

Figure 16. Relations between detachment rate for all data and $A$, Non-uniform shear stress. $B$, Non-uniform stream power. 

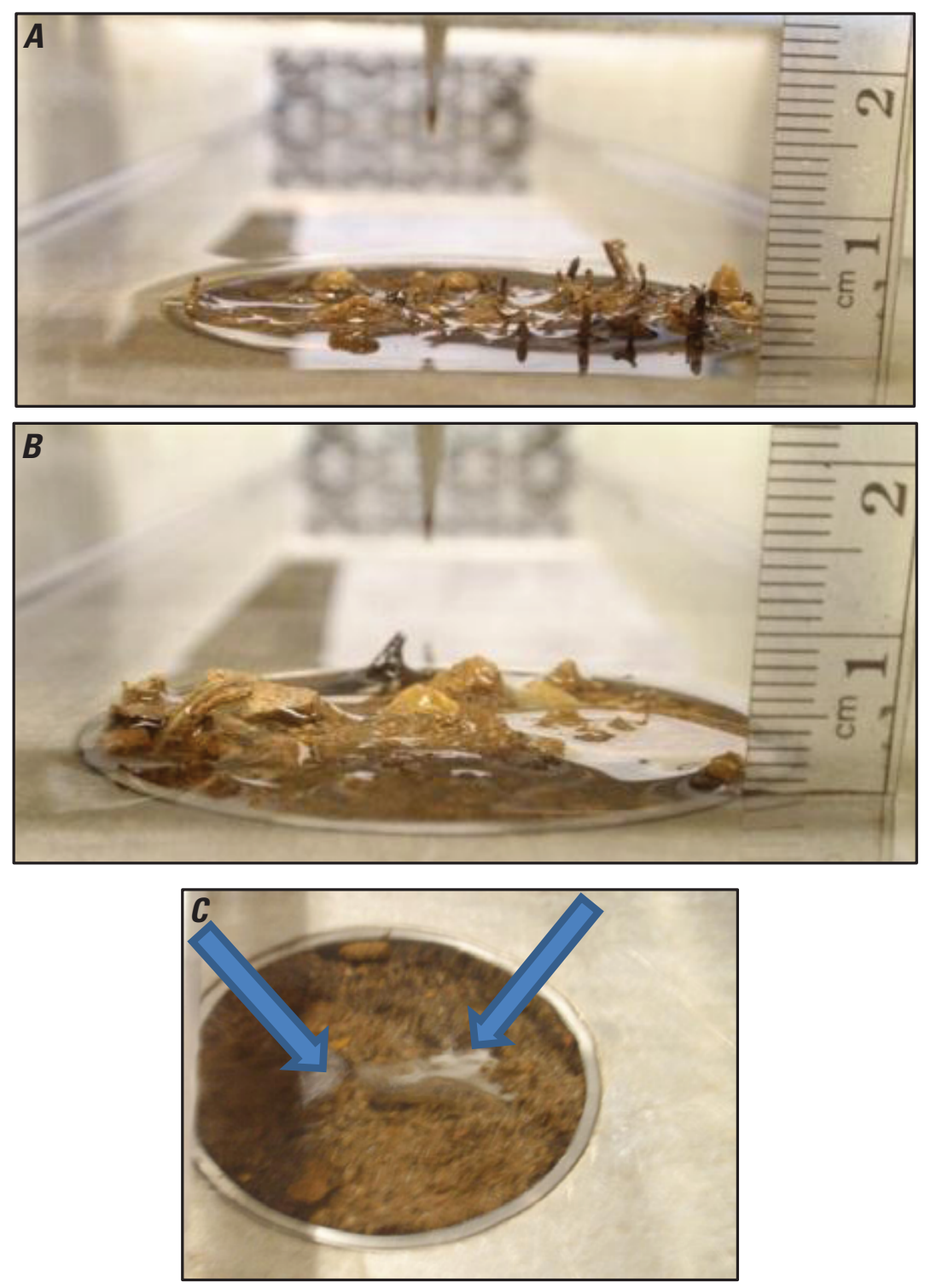

Figure 17. Photographs of the appearance of the surface of the soil core in the tilting flume. $A$, View looking upstream along the bed of the tilting flume showing some protruding roots and pits filled with water. The tip of point gage extends from the top of the photo, and the dark gray grid in the background is the diffuser. The diameter of the inside of the core is $4.7 \mathrm{~cm}$. $B$, View looking upstream along the bed of the tilting flume showing some protruding sand and fine gravel particles. $C$, Oblique view across the soil core showing the air films (whitish gray objects at end of blue arrows) attached to the soil surface. Flow is from right to left. 


\section{Summary}

The heat released during wildfires affects sediment availability through soil heating and the combustion of vegetation, litter, and organic material within the soil. This can result in a temporary or permanent change in erodibility of soils, such that detachment and transport by overland flow is easier. This study aimed to quantify the erodibility of burned soil at different depths and relate variability in detachment rate to different flow and soil properties. Soil cores were collected (to measure erodibility using a shallow, tilting flume and to measure soil and root properties) from two different burned areas (2010 Fourmile Canyon fire in Colorado and 2010 Pozo fire area in California) with contrasting geology, soil-particle size, and vegetative characteristics.

Soil properties (bulk density, organic matter, and amount of silt and clay) and root properties (root density $(R D)$ and root-length density $(R L D)$ ) showed distinct trends with soil depth. All sites displayed an increase in bulk density with depth and a slight decrease in organic matter (loss on ignition) and percent of silt and clay with depth below the surface. Bulk density and soil organic matter were relatively similar across the three sites, but percent silt and clay was generally higher in the Pozo site than in the FMC sites. At all sites, the $R D$ and $R L D$ were lowest near the soil surface. At the two sites in Fourmile Canyon, the root properties had maxima between 2 and $5 \mathrm{~cm}$ below the soil surface, whereas at Pozo, the $R D$ and $R L D$ increased monotonically with depth.

Detachment rates for burned and unburned soils were measured using a tilting flume which was modified so that the cylindrical cores could be inserted, attached below the flume bed (so that they were flush with the flume bed), and then could be extruded to exposed different depths below the soil surface. The detachment rate of burned soil cores decreased by up to 1-2 orders of magnitude between surface and subsurface soils in the top $2 \mathrm{~cm}$ of the soil profile. Subsurface soils from the Pozo site had lower variability in detachment rates than soils from the Fourmile Canyon site.

The relation between detachment rate and flow variables was a power law for each depth in individual clusters, but the exponent was quite variable. The depth-averaged exponent for each cluster varied from 0.34 to 1.34 across all burned sites. Additional variability in detachment rates of burned soil could be linked to $R L D$. A multivariate regression indicated that the detachment rate of burned soils $E\left[\mathrm{~g} \mathrm{~cm}^{-2} \mathrm{~s}^{-1}\right]$ was a function of the flow variable, $\tau_{N}\left[\right.$ dyne $\left.\mathrm{cm}^{-2}\right]$, and the root variable, $R L D[\mathrm{~cm}$ $\left.\mathrm{cm}^{-3}\right]$. The general form of the relation for the detachment rate, $E$ was:

$$
E=b 1 t_{N}^{b 2} R L D^{b 3}
$$

where

the average values (for all clusters from all burned areas) were $b 1=-1.80, b 2=0.82$ and $b 3=-0.88$. Similar results were found using the non-uniform stream power $(b 1=-3.62$, $b 2=0.67$, and $b 3=-0.89$ ). These results indicate that the erodibility parameters for soil within burned areas need to include depth and root properties.

\section{Acknowledgments}

Soil cores for this study were collected on Bureau of Land Management (BLM) and U.S. Forest Service (USFS) property in the area burned by the 2010 Fourmile Canyon Fire. John Smeins (BLM) and Erin Watkins (BLM) expedited the process of obtaining permission to collect the samples, and Eric Schroder (USFS, Arapaho/Roosevelt National Forest) made repeated trips to the field site to help identify sites. Melody Fountain (USFS, Los Padres National Forest) gave us a guided tour into the area burned by the 2010 Pozo Fire in California, which saved an enormous amount of time dedicated to finding and deciding on a representative site. Dick Martin (Martin Enterprises, Lakewood, Colorado) was instrumental in making changes to the tilting flume to accommodate the soil cores and in designing and fabricating the core holder and extruding device. The diagrams in Figure 6 were prepared by Graeme Scheuber. Pierce Martin stepped in at a crucial time to finish much of the soil particle-size analysis that is essential, but often tedious to complete.

The project was partially funded by eWater Cooperative Research Centre and Melbourne Water. The second author was funded by a post-graduate travel scholarship from The University of Melbourne. Reviews by Brian Ebel and Christoph Langhans improved the report.

\section{References Cited}

Al-Hamdan, O.Z., Pierson, F.B., Williams, C.J., Nearing, M.A., Stone, J.J., Kormos, P.R., Boll, Jan, and Weltz, M.A., 2011, Estimating concentrated flow erodibility parameters from pre- and post-fire rangeland field data for physicallybased erosion modeling: American Geophysical Union, AGU Poster H31B-1141.

Bagnold, R.A., 1966, An approach to the sediment transport problem from general physics: U.S. Geological Survey Professional Paper 422-I, 37 p.

Blake, W.H., Droppo, I.G., Humphreys, G.S., Doerr, S.H., Shakesby, R.A. and Wallbrink, P.J., 2007, Structural characteristics and behavior of fire-modified soil aggregates: Journal of Geophysical Research, v. 112, doi:10.1029/2006JF000660.

Brown, S.H., 2009, Multiple linear regression analysis-A matrix approach with MATLAB: Alabama Journal of Mathematics, Spring/Fall 2009, p. 1-3.

Bryan, R.B., 2000, Soil erodibility and processes of water erosion on hillslope: Geomorphology, v. 32, p. 385-415. 
Busse, M.D., and DeBano, L.F., 2005, Chapter 4-Soil Biology, in Neary, D.G., Ryan, K.E., and DeBano, L.F., eds., Wildland fire in ecosystems, effects of fire on soil and water: Ogden, Utah, U.S. Department of Agriculture, Forest Service, Rocky Mountain Research Station, General Technical Report RMRS-GTR-42-vol.4., p. 73-91.

DeBano, L.F., 2000, The role of fire and soil heating on water repellency in wildland environments - A review: Journal of Hydrology, v. 231/232, p. 195-206.

DeBano, L.F., and Neary, D.G., 2005, Part A-The soil resource-Its importance, characteristics, and general responses to fire, in Neary, D.G., Ryan, K.E., and DeBano, L.F., eds., Wildland fire in ecosystems, effects of fire on soil and water: Ogden, Utah, U.S. Department of Agriculture, Forest Service, Rocky Mountain Research Station General Technical Report RMRS-GTR-42-vol.4., p. 21-27.

DeBano, L.F., Neary, D.G., and Ffolliott, P.F. 2005, Chapter 2-The soil physical properties, in Neary, D.G., Ryan, K.E., and DeBano, L.F., eds., Wildland fire in ecosystems, effects of fire on soil and water: Ogden, Utah, U.S. Department of Agriculture, Forest Service, Rocky Mountain Research Station, General Technical Report RMRS-GTR-42-vol.4, p. $29-51$.

De Baets, S. Poesen, J., Kanapen, A., and Galindo, P. 2007, Impact of root architecture on the erosion-reducing potential of roots during concentrated flow: Earth Surface Processes and Landforms, v. 32, p. 1323-1345.

Dingman, S.L., 1984, Fluvial Hydrology, W.H. Freeman and Company, New York, 383 p.

Elliot,W.J., Liebenow, A.M., Laflen, J.M. and Kohl, K.D., 1989, A compendium of soil erodibility data from WEPP cropland soil field erodibility experiments 1987 and 1988: National Science and Engineering Research Laboratory (NSERL) Report No. 3, The Ohio State University and USDA Agricultural Research Service, 23 p, with multiple tables, accessed December 22, 2011, at http://www.ars.usda. gov/SP2UserFiles/ad_hoc/36021500WEPP/weppbiblio.pdf.

Foster, G.R., Meyer, L.D., 1975, Mathematical simulation of upland erosion using fundamental erosion mechanics, in Present and prospective technology for predicting sediment yields and sources, Oxford, Miss., 1972, Proceedings: USDA Sedimentation Laboratory, Sediment-Yield Workshop, U.S. Agricultural Research Service (Rep) ARS-S-40, p. 190-207.

Foster, G.R., 1982, Modeling the erosion process, chap. 8 of Haan, C.T., ed., Hydrologic modeling of small watersheds: St. Joseph, Mich., American Society of Agricultural Engineers, ASAE Monograph No. 5, p. 297-360.
Foster, G.R., Flanagan, D.C., Nearing, M.A., Lane, L.J., Risse, L.M., and Finkner, S.C., 1995, Hillslope erosion component, chap. 11 of Flanagan, D.C. and Nearing, M.A., eds., USDA Water Erosion Prediction Project, NSERL Report No. 10: West Lafayette, Ind., National Soil Erosion Research Laboratory, p. 11.1-11.10.

Gable, D.J., 1980, Geologic map of the Gold Hill quadrangle, Boulder County, Colorado: U.S. Geological Survey, Geologic Quadrangle Map GQ-1525, scale 1:24,000.

Giovannini, Giacomo, Lucchesi, S., and Giachetti, M., 1988, Effect of heating on some physical and chemical parameters related to soil aggregation and erodibility: Soil Science, v. 146 , no. 4 , p. 255-261.

Grabowski, R.C., Droppo, I.G., and Wharton, G., 2011, Erodibility of cohesive sediments - The importance of sediment properties: Earth-Science Reviews, v. 105, p. 101-120.

Guy, H.P. 1977, Laboratory theory and methods for sediment analysis: Techniques of Water-Resources Investigations of the United States Geological Survey, Chap. C1, Book 5, $58 \mathrm{p}$.

Gyssels, G., Poesen, J., Bochet, E., and Li, Y., 2005, Impacts of plant roots on the resistance of soils to erosion by water-A review: Progress in Physical Geography, v. 29, p. 189-217.

Hairsine, P.B., and Rose, C.W., 1992, Modeling water erosion due to overland flow using physical principles, 1 . Sheet flow: Water Resources Research, v. 28, no. 1, p. 237-243.

Heiri, O., Lotter, A.F., and Lemcke, G., 2001, Loss on ignition as a method for estimating organic and carbonate content in sediments - Reproducibility and comparability of results: Journal of Paleolimnology, v. 25, p. 101-110.

Huang, Jianchun, Hilldale, R.C., and Greimann, B.P., 2006, Cohesive sediment transport, chap. 4 of Erosion and sedimentation manual: U.S. Bureau of Reclamation, p. 4-1-4-54.

Julien, P.Y., 1998, Erosion and sedimentation: New York, N.Y., Cambridge University Press, 280 p.

Kluber, L.A., Tinnes, K.M., Caldwell, B.A., Dunham, S.M., Yarwood, R.R., Bottomley, P.J., Myrold, D.D., 2010, Ectomycorrhizal mats alter forest soil biogeochemistry: Soil Biology and Biochemistry, v. 42, no. 9, p. 1607-1613.

Knoepp, J.D., and DeBano, L.F., 2005, Chapter 3-Soil chemistry, in Neary, D.G., Ryan, K.E., and DeBano, L.F., eds., Wildland fire in ecosystems, effects of fire on soil and water: Ogden, Utah, U.S. Department of Agriculture, Forest Service, Rocky Mountain Research Station, General Technical Report RMRS-GTR-42-vol.4, p. 53-71. 
Kroll, C.N., and Stedinger, J.R., 1996, Estimation of moments and quantiles using censored data: Water Resources Research, no. 32, v. 4, p. 1005-1012.

Lane, L.J., Foster, G.R., and Nicks, A.D., 1987, Use of fundamental erosion mechanics in erosion prediction: St. Joseph, Miss., ASAE, Paper No. 87-2540, 10 p.

Meyer-Peter, E., and Müller, R., 1948, Formulas for bed-load transport: International Association of Hydraulic Structures Research, Stockholm, 7-9 June 1948, p. 39-64.

Moody, J.A., Smith, J.D., and Ragan, B.W., 2005, Critical shear stress for erosion of cohesive soils subjected to temperatures typical of wildfires: Journal of Geophysical Research, v. 110, doi 10.1029/2004JF000141.

Moody, J.A., and Martin, D.A., 2009, Forest fire effects on geomorphic processes, chap. 2 of Cerdà, A., and Robichaud, P.R., eds., Fire effects on soils and restoration strategies, Volume 5-Land and reconstruction and management: Enfield, N.H., Science Publishers, p. 41-79.

Nachtergaele, Jeroen, and Poesen, Jean, 2002, Spatial and temporal variations in resistance of loess-derived soils to ephemeral gully erosion: European Journal of Soil Science, v. 53, p. 449-463.

National Oceanic and Atmospheric Administration, 2000, Climatography of the United States No. 81, Monthly station normal of temperature, precipitation, and heating and cooling degree days 1971-2000, 04 California (73 p) and 05 Colorado (40. P): Asheville, N.C., National Oceanic and Atmospheric Administration.

Nyman, Peter, Sheridan, G.J., Smith, H.G., and Lane, P.N.J., 2011, Evidence of debris flow occurrence after wildfire in upland catchments of south-east Australia: Geomorphology, v. 125 , p. $383-401$.

Pepin, N., 2000, Twentieth-century change in the climate record for the Front Range, Colorado, U.S.A.: Arctic, Antarctic, and Alpine Research, v. 32, no. 2, p. 135-146.

Roberts, Jesse, Jepsen, Rich, Gotthard, Doug, and Lick, Wilbert, 1998, Effect of particle size and bulk density on erosion of quartz particles: Journal of Hydraulic Engineering, v. 124, p. 1261-1267.

Robichaud, P.R., Wagenbrenner, J.W., and Brown, R.E., 2010, Rill erosion in natural and disturbed forests - 1 . Measurements: Water Resources Research, v. 46, W10506, doi:10.1029/2009WR008314, 14 p.

Sheridan, G.J., Lane, P.N.J, and Noske, P.J., 2007, Quantification of hillslope runoff and erosion processes before and after wildfire in a wet Eucalyptus forest: Journal of Hydrology, v. 343, no. 1-2, p. 12-28.
Smith, J.D., 2004, The role of riparian shrubs in preventing floodplain unraveling along the Clark Fork of the Columbia River in the Deer Lodge Valley, Montana: American Geophysical Union, Riparian Vegetation and Fluvial Geomorphology, Water Science and Application 8, p. 77-85.

Tennant, D., 1975, A test of a modified line intersect method of estimating root length: Journal of Ecology, v. 63, p. $995-1001$.

U.S. Department of Agriculture Soil Survey Staff, 2011, Natural Resource Conservation Service: U.S. Department of Agriculture, Web Soil Survey, accessed December 22, 2012 , at http://websoilsurvey.nrcs.usda.gov/ and https://soilseries. sc.egov.usda.gov.

U.S. Forest Service, 2011, Forest geology of Los Padres National Forest: U.S. Forest Service, accessed December 22, 2011, at http://www.fs.usda.gov/wps/portal/ fsinternet/!ut/p/c4/04_SB8K8xLLM9MSSzPy8xBz9CP0os3g jAwhwtDDw9_AI8zPyhQoY6BdkOyoCAGixyPg!/?ss=1105 07\&navtype $=\bar{B}$ ROWSEBYSUBJECT\&cid $=$ Ssm9_034082\&n avid $=150130000000000 \&$ pnavid $=150000000000000 \&$ pos ition $=$ Not Yet Determined.Html\&type $=$ detail\&pname $=$ Los Padres National Forest-Nature \& Science.

Wiberg, P.L., and Smith, J.D.,1987, Calculations of the critical shear stress for motion of uniform and heterogeneous sediments: Water Resources Research, v. 23, p. 1471-1480.

Yang, C.T., 1972, Unit stream power and sediment transport: Journal of the Hydraulic Division, American Society of Civil Engineers, v. 98, no. 10, p. 1805-1826.

Yang, C.T., 2006, Noncohesive sediment transport, chap. 3 of Erosion and Sedimentation Manual: U.S. Bureau of Reclamation, p. 3-1-3-111.

Publishing support provided by:

Denver Publishing Service Center

For more information concerning this publication, contact:

Chief, Branch of Regional Research, Central Region

U.S. Geological Survey

Box 25046, Mail Stop 418

Denver, CO 80225

(303) 236-5021

Or visit the USGS National Research Program Web site at: http://water.usgs.gov/nrp/ 
